UNIVERSIDADE DE SÃO PAULO

INSTITUTO DE GEOCIENCIAS

\title{
ESTUDO EXPERIMENTAL DE RETENÇÃO DE ÍONS METÁLICOS EM VERMICULITA
}

\author{
Mirian Chieko Shinzato
}

Orientador: Prof. Dr. Raphael Hypolito

DISSERTAÇÃO DE MESTRADO

Programa de Pós-Graduação em Mineralogia e Petrologia 


\section{UNIVERSIDADE DE SÃO PAULO INSTITUTO DE GEOCIENCIAS}

\section{ESTUDO EXPERIMENTAL DE RETENÇÃO DE ÍONS METÁLICOS EM VERMICULITA}

Mirian Chieko Shinzato

Orientador: Prof. Dr. Raphael Hypolito

\section{DISSERTAÇÃO DE MESTRADO}

COMISSÃO JULGADORA

nome

Presidente: Prof.Dr. Raphael Hypólito

Examinadores: Prof.Dr. José Vicente Valarelli

Prof.Dr. Adilson Carvalho

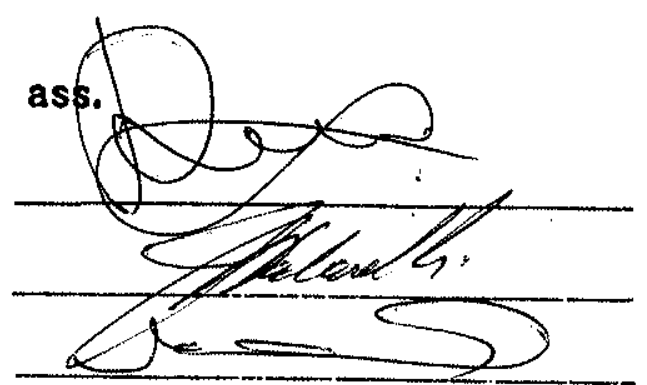




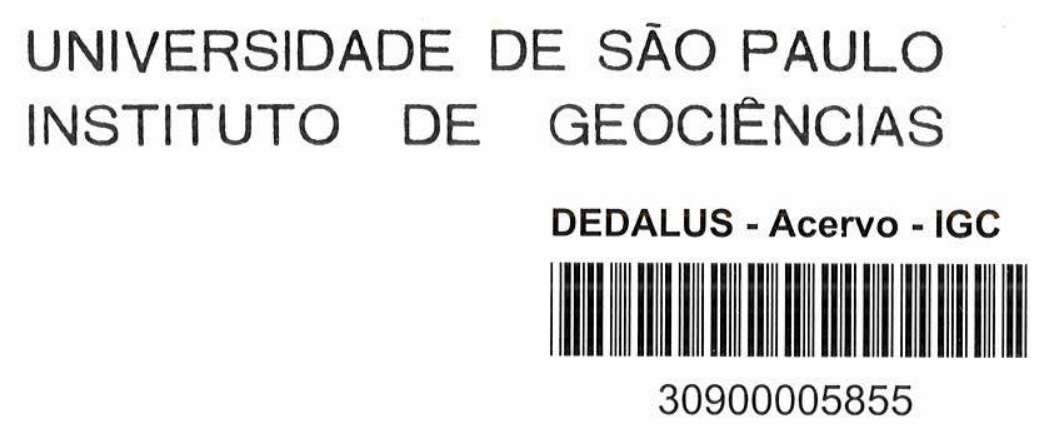

\title{
ESTUDO EXPERIMENTAL DE RETENÇĀO DE ÍONS METÁLICOS EM VERMICULITA
}

\author{
Mirian Chieko Shinzato
}

Orientador: Prof. Dr. Raphael Hypolito

\author{
DISSERTAÇÃO DE MESTRADO
}

Programa de Pós-Graduação em Mineralogia e Petrologia

São Paulo

1995 


\section{ÍNDICE}

$\begin{array}{ll}\text { I. Introdução } & 01\end{array}$

1. Generalidades 01

2. Objetivo 02

3. Revisão Bibliográfica 03

3.1. Histórico 03

3.2. Estrutura Cristalina 04

3.2.1. Carga Estrutural 08

3.3. Propriedades da Vermiculita 10

3.3.1. Comportamento Térmico 10

3.3.2. Expansão 11

3.3.3. Vermiculitização 15

3.3.4. Troca Catiônica 17

II. Materiais e Métodos 21

1. Materiais 21

2. Preparação das Amostras 22

3. Métodos 22

III. Caracterização dos Materiais $\mathbf{2 4}$

1. Análise Mineralógica por Difração de raios-X (DRX) 24

2. Análise Termodiferencial (ATD) e Termogravimétrica (ATG) 28

3. Microscopia Eletrônica 35

4. Superficie Específica (SE) 37

5. Análise Química 40

5.1. Fórmula Estrutural da vermiculita de Massapé-Paulistana (PI) 42

6. Capacidade de Troca Catiônica (CTC) 45

7. Relação Composicional entre Vermiculita e Mica de Origem 50

IV. Trabalhos Experimentais 51

1. Experiência A (1 fase): escolha da granulometria favorável à troca 51

2. Experiência B (3 fases): troca com soluções salinas 54

3. Experiência C (3 fases): troca com metais pesados 73

V. Conclusões $\quad 83$

VI. Referências Bibliográficas $\quad 85$ 


\section{ÍNDICE DAS ILUSTRAÇÕES}

\section{FIGURAS}

1- Desenho esquemático da estrutura da vermiculita.

2- Desenho esquemático da superposição dos planos $R^{\prime}$ e $Q^{\prime}$, segundo o eixo cristalográfico "c", dos sítios das moléculas de água em relação à posição 06 dos cátions magnésio interfoliares de uma vermiculita magnesiana.

3- Estrutura cristalina de uma vermiculita-Mg: projeção normal ao plano "ac" (a), projeção normal ao plano "ab", mostrando a região interfoliar (b) e projeção normal ao plano "ab", mostrando a folha silicática (c).

4- Projeção normal ao plano "ac" da estrutura de uma vermiculita-Mg mostrando as fases de hidratação.

5- Esquema das etapas envolvidas na determinação da CTC em argilominerais

6- Localização da jazida de vermiculita de Massapé-Paulistana (PI). 21

7- Difratograma de raios X da amostra natural M-1. 25

8- Difratogramas de raios $X$ das amostras aquecidas. 26

9- Difratograma de raios $X$ da enstatita formada a partir do colapso da estrutura da vermiculita de Massapé-Paulistana.

10- Curvas termodiferenciais na versão Mettler TA 72.5 da amostra M-1. 29

11- Curvas termodiferenciais na versão Mettler TA 72.5 da amostra M-2. 30

12- Curvas termodiferenciais na versão Mettler TA 72.5 da amostra M-4. 30

13- Curvas termogravimétrica (TG) e termoponderada (DTG) na versão Mettler TA 72.5 da amostra M-1.

14- Curvas termogravimétrica (TG) e termoponderada (DTG) na versão Mettler TA 72.5 da amostra M-2.

15- Curvas termogravimétrica (TG) e termoponderada (DTG) na versão Mettler TA 72.5 da amostra M-4.

16- Gráfico de comparação entre as curvas termogravimétricas das amostras M-1, M-2 e M-4.

17- Micrografia eletrônica de transmissão da amostra M-1.

18- Micrografia eletrônica de transmissão da amostra M-2.

19. Micrografia eletrônica de transmissão da amostra M-4.

20- Micrografias eletrônicas de varredura da amostra M-4 (a e b).

21- Representação esquemática da estrutura da vermiculita indicando as superficies externa e interna. 
22- Diagrama obtido por EDS para a vermiculita de Massapé-Paulistana.

23- Esquema do método de obtenção de CTC.

24- Esquema do método simplificado de obtenção de CTC.

25- Relação entre $\mathrm{Mg}^{2+}, \mathrm{Fe}^{2+}\left(\mathrm{Mn}^{2+}\right)$ e $\mathrm{R}^{3+}\left(\mathrm{Al}^{3+}, \mathrm{Fe}^{3+}\right)$ das micas trioctaédricas.

26- Projeção dos teores dos íons cálcio e potássio liberados para a solução em função do tempo de tratamento da experiência $\mathrm{A}$.

27- Difratogramas de raios $X$ das amostras de vermiculita (M-1) tratadas com $\mathrm{NaCl}(\mathrm{N})$.

28- Difratogramas de raios $\mathrm{X}$ das amostras de vermiculita (M-1) tratadas com $\mathrm{BaCl}_{2} \cdot 2 \mathrm{H}_{2} \mathrm{O}(\mathrm{N})$.

29- Difratogramas de raios $\mathrm{X}$ das amostras de vermiculita (M-1) tratadas com $\mathrm{KCL}(\mathrm{N})$.

30- Difratogramas de raios $\mathrm{X}$ das amostras de vermiculita (M-1) tratadas com $\mathrm{MgCl}_{2} \cdot 6 \mathrm{H}_{2} \mathrm{O}(\mathrm{N})$.

31 - Difratogramas de raios $\mathrm{X}$ das amostras de vermiculita (M-1) tratadas com EDTA $(0,04 M)$.

32- Projeção dos teores dos ions cálcio e potássio liberados da estrutura da vermiculita para a solução, em função do tempo de tratamento com $\mathrm{NaCl}$ (N).

33- Projeção dos teores dos íons cálcio e potássio liberados da estrutura da vermiculita para a solução, em função do tempo de tratamento com 65 $\mathrm{BaCl}_{2} \cdot 2 \mathrm{H}_{2} \mathrm{O}(\mathrm{N})$.

34- Projeção dos teores dos íons cálcio e potássio liberados da estrutura da vermiculita para a solução, em função do tempo de tratamento com KCL 65 (N).

35- Projeção dos teores dos íons cálcio e potássio liberados da estrutura da vermiculita para a solução, em função do tempo de tratamento com 66 $\mathrm{MgCl}_{2} \cdot 6 \mathrm{H}_{2} \mathrm{O}(\mathrm{N})$.

36- Projeção dos teores dos íons cálcio e potássio liberados da estrutura da vermiculita para a solução, em função do tempo de tratamento com EDTA 66 $(0,04 \mathrm{M})$.

37- Representação esquemática de troca iônica realizada na obtenção de vermiculita- $\mathrm{H}_{3} \mathrm{O}^{+}$.

38- Difratograma de raios $\mathrm{X}$ da amostra de VBa-40 tratada com EDTA $(0,04 \mathrm{M})$.

39- Difratograma de raios $X$ da amostra $M-1$ tratada com solução de $\mathrm{Pb}\left(\mathrm{NO}_{3}\right)_{2}$. 
40- Difratograma de raios $\mathrm{X}$ da amostra $\mathrm{VMg}-30$ tratada com solução de $\mathrm{Pb}\left(\mathrm{NO}_{3}\right)_{2}$.

41- Difratograma de raios $\mathrm{X}$ da amostra $\mathrm{VH}_{3} \mathrm{O}$ tratada com solução de $\mathrm{Pb}\left(\mathrm{NO}_{3}\right)_{2}$.

42- Difratograma de raios $\mathrm{X}$ da amostra $\mathrm{M}-1$ tratada com solução de $\mathrm{Ni}\left(\mathrm{NO}_{3}\right)_{2} .6 \mathrm{H}_{2} \mathrm{O}$.

43- Difratograma de raios $\mathrm{X}$ da amostra $\mathrm{VMg}-30$ tratada com solução de $\mathrm{Ni}\left(\mathrm{NO}_{3}\right)_{2} \cdot 6 \mathrm{H}_{2} \mathrm{O}$.

44- Difratograma de raios $\mathrm{X}$ da amostra $\mathrm{VH}_{3} \mathrm{O}$ tratada com solução de $\mathrm{Ni}\left(\mathrm{NO}_{3}\right)_{2} \cdot 6 \mathrm{H}_{2} \mathrm{O}$

45- Difratograma de raios $X$ da amostra $\mathrm{M}-1$ tratada com solução de $\mathrm{Cu}(\mathrm{Ac})_{2} \cdot \mathrm{H}_{2} \mathrm{O}$.

46- Difratograma de raios $\mathrm{X}$ da amostra $\mathrm{VMg}-30$ tratada com solução de $\mathrm{Cu}(\mathrm{Ac})_{2} \cdot \mathrm{H}_{2} \mathrm{O}$

47- Difratograma de raios $\mathrm{X}$ da amostra $\mathrm{VH}_{3} \mathrm{O}$ tratada com solução de $\mathrm{Cu}(\mathrm{Ac})_{2} \cdot \mathrm{H}_{2} \mathrm{O}$

\section{TABELAS}

I. Niveis de hidratação dos cátions.

II. Métodos analíticos utilizados para a análise química da vermiculita de Massapé-Paulistana (PI).

III. Reflexão basal d(002) das vermiculitas crua (M-1) e expandida (M-3) de Massapé-Paulistana, antes e após tratamentos com etileno-glicol e 25 aquecimento

IV. Principais picos endotérmicos da vermiculita de Massapé-Paulistana obtidos pelos métodos Mettler TA 72.5 e TC-11

V. Superficie específica das vermiculitas crua fina (M-1) e grossa (M-2), e da expandida grossa (M-4), obtidas pelo método de BET e etileno- 39 glicol.

VI. Principais constituintes químicos da vermiculita estudada.

VII. Cálculo do conteúdo atômico da cela unitária da vermiculita de Massapé-Paulistana 
VIII. Capacidade de troca de cátions (CTC) da vermiculita de MassapéPaulistana.

IX. Teores de cálcio e potássio extraídos da estrutura das amostras $\mathrm{M}-1$ e M-2 lixiviadas com $\mathrm{MgCl}_{2} \cdot 6 \mathrm{H}_{2} \mathrm{O}(\mathrm{N})$ na experiência $\mathrm{A}$.

$\mathrm{X}$. Amostras tratadas com soluções salinas em períodos variados.

XI. Teores de $\mathrm{Ca}^{2+}, \mathrm{Mg}^{2+} \mathrm{e} \mathrm{K}^{+}$removidos da estrutura da vermiculita por soluções salinas.

XII. Teores dos cátions das soluções salinas que substituíram o cálcio e o potássio interfoliares das amostras de vermiculita estudadas.

XIII. Efeito dos íons trocáveis na expansão da estrutura da vermiculita.

XIV. Teores de $\mathrm{Na}^{+}$e $\mathrm{K}^{+}$removidos da estrutura das amostras VK-40 e VNa40 através de lixiviação com solução clorídrica $(\mathrm{M})$.

$\mathrm{XV}$. Teores de cátions metálicos na solução original e os retidos na estrutura das amostras estudadas ( $\mathrm{M}-1, \mathrm{VMg}-30$ e $\mathrm{VH}_{3} \mathrm{O}$ ), após respectivos 74 tratamentos.

XVI. Valores de $\delta_{\mathrm{c}}$ dos cátions envolvidos no processo de troca do experimento $\mathrm{C}$ ( $1^{\mathrm{a}}$ fase).

XVII. Concentrações dos íons metálicos do efluente industrial retidos nas amostras estudadas ( $\left.\mathrm{M}-1, \mathrm{VMg}-30 \mathrm{e} \mathrm{VH}_{3} \mathrm{O}\right)$.

XVIII Concentração dos íons metálicos liberados das amostras para a solução de lixiviação (EDTA 0,04M). 


\section{AGRADECIMENTOS}

Após mais uma etapa concluída, deixo aqui meus sinceros agradecimentos a todas as pessoas que participaram direta e/ou indiretamente na elaboração deste trabalho.

Ao Prof. Dr. Raphael Hypolito, por ter incentivado e contribuido para o meu desenvolvimento científico (desde a graduação) e, principalmente, pela dedicada orientação.

Ao Prof. Dr. José Vicente Valarelli, pelo estímulo e pelas sempre preciosas sugestões.

Ao Prof. Dr. Rudolf Giovanoli, da Universidade de Berna, pela importante colaboração na obtenção e interpretação de micrografias eletrônicas, análises termogravimétricas e termodiferenciais e determinação da superficie especifica pelo método de BET.

Especial agradecimento ao geólogo Silvio Takashi Hiruma pelo constante incentivo e companhia durante a confecção deste trabalho.

Aos químicos Sandra Andrade, Marinês Lopes da Silva e Manoel Balbino, e ao técnico Ricardo Silva Cardenete, pelas análises químicas e companhia durante a execução dos trabalhos experimentais nos laboratórios de química do Departamento de Mineralogia e Petrologia. Destes, registro aqui especial agradecimento à Sandra, pelo auxílio e sugestões na elaboração dos trabalhos experimentais.

Ao Prof. Dr. Daniel Atencio pelas críticas e sugestões e ao físico Flávio Machado de Souza Carvalho, pela confecção dos difratogramas de raios $X$.

Ao Prof. Dr. Thomas Fairchild pela revisão do texto em inglês; à Moacir Vargas, pela micronização das amostras; ao geólogo José Luis Fernando e à química Dra. Antônia Sônia Stachissini, pelo apoio na pesquisa bibliográfica e na determinação de CTC. À bolsista Isabel Shizuka lto e à geóloga Ivone da Silva Silveira, pela contribuição na parte experimental deste trabaiho.

Aos colegas de pós-graduação deste Instituto e, principalmente à Silvania, Sandra Iwata, Valquíria e Annabel pelo apoio e companhia durante 0 desenvolvimento deste trabalho.

Aos desenhistas Itacy Kroehne e Francisco J.P. Almeida Filho pela execução dos gráficos. Ao Sr. Dalton Machado da Silva, Claudionor Barboza e equipe gráfica pela confecção final deste trabalho. À equipe da biblioteca do IGc/USP, em especial à Estela, Cida e Cícero; às secretárias da Pós-Graduação, Madalena e Regina; aos secretários do DMP, Marta e Tadeu, pelos serviços prestados e simpatia com que sempre atenderam. 
Aos órgãos financiadores deste projeto, CNPq (processo no 303206/87-0/RN) e FAPESP (processo 93/3621-0), pela concessão de recursos que muito auxiliaram na realização deste trabalho.

Finalmente, dedico este trabalho aos meus pais e irmãos, pelo auxilio e apoio durante todo o tempo utilizado para a execução desta e muitas outras realizações. 


\section{RESUMO}

A vermiculita é um mineral secundário resultante da alteração de micas; geralmente é encontrada na forma de placas centimétricas (vermiculita macroscópica), ou na fração argila de solos.

Neste trabalho, a vermiculita macroscópica proveniente da jazida de Massapé-Paulistana, localizada no município de Paulistana, sudeste do Estado de Piauí, foi utilizada nas formas natural e piroexpandida, com o objetivo de estudar sua propriedade de reter metais em solução. Análises quimicas e mineralógicas permitiram definir a seguinte fórmula estrutural para o mineral estudado:

$$
\begin{gathered}
\left(\mathrm{Ca}_{0.256} \mathrm{~K}_{0.159} \mathrm{Na}_{0.058}\right)\left(\mathrm{Mg}_{2.56} \mathrm{Fe}^{3+}{ }_{0.255} \mathrm{Fe}^{2+}{ }_{0.092} \mathrm{Ti}_{0.042} \mathrm{Mn}_{0.005} \mathrm{Li}_{0.005}\right) \\
{\left[\left(\mathrm{Si}_{3.043} \mathrm{Al}_{0.848} \mathrm{Fe}^{3+}{ }_{0.109}\right) \mathrm{O}_{10}\right] \cdot(\mathrm{OH})_{2} \cdot 4.16 \mathrm{H}_{2} \mathrm{O}}
\end{gathered}
$$

A vermiculita de Massapé-Paulistana apresenta superfície especifica (SE) e capacidade de troca catiônica (CTC) elevadas, quando micronizadas ( $<200$ mesh). A sua forma piroexpandida apresenta, no entanto, uma SE maior que a amostra natural, porém a sua CTC é mais baixa. A pequena CTC apresentada pela amostra expandida decorre da perda de água interfoliar durante o processo de piroexpansão, dificultando, desta forma, a mobilidade dos cátions na posição interfoliar.

Experiências realizadas com a amostra natural micronizada utilizando soluções salinas de natureza diversas $\left(\mathrm{Na}^{+}, \mathrm{K}^{+}, \mathrm{Ba}^{2+}, \mathrm{Mg}^{2+}, \mathrm{H}_{3} \mathrm{O}^{+}\right)$permitiram verificar que a facilidade de troca catiônica está diretamente relacionada com as características dos íons: quanto maior o grau de hidratação do cátion interfoliar do mineral, em relação ao do cátion da solução, maior é sua facilidade de troca. Por este motivo, procurou-se utilizar, para os ensaios de troca iônica com metais pesados $\left(\mathrm{Pb}^{2+}, \mathrm{Cu}^{2+}, \mathrm{Ni}^{2+}\right)$, amostras de vermiculita natural e aquelas saturadas previamente com cátions altamente hidratáveis $\left(\mathrm{H}_{3} \mathrm{O}^{+}, \mathrm{Mg}^{2+}\right)$.

Obteve-se para a vermiculita com $\mathrm{H}_{3} \mathrm{O}^{+}$resultados satisfatórios em ensaios de troca com os íns cobre, chumbo e níquel. $A$ amostra natural e aquela saturada com magnésio mostraram-se eficientes na troca com chumbo, entretanto, exibiram eficiências razoáveis na troca com niquel e cobre. A recuperação destes metais pesados retidos na estrutura das vermiculitas foi efetuada utilizando-se soluções de EDTA para acelerar o processo de troca. 
Vermiculite is a secondary mineral derived from mica weathering and is found generally as centimetric flakes (macroscopic vermiculite) or as a clay mineral in soil.

In this work macroscopic vermiculite from the Massapé-Paulistana deposit, near Paulistana, southeast Piaui, was employed in its natural and expanded forms to study its property in exchanging metals in solution. Chemical and mineralogical analyses of natural vermiculite defined its structural formula as:

$$
\begin{gathered}
\left(\mathrm{Ca}_{0.256} \mathrm{~K}_{0.159} \mathrm{Na}_{0.058}\right)\left(\mathrm{Mg}_{2.56} \mathrm{Fe}^{3+}{ }_{0.255} \mathrm{Fe}^{2+}{ }_{0.092} \mathrm{Ti}_{0.042} \mathrm{Mn}_{0.005} \mathrm{Li}_{0.005}\right) \\
{\left[\left(\mathrm{Si}_{3.043} \mathrm{Al}_{0.848} \mathrm{Fe}^{3+}{ }_{0.109}\right) \mathrm{O}_{10}\right] \cdot(\mathrm{OH})_{2} \cdot 4.16 \mathrm{H}_{2} \mathrm{O}}
\end{gathered}
$$

When in fine grains (<200 mesh), the Massapé-Paulistana macroscopic vermiculite has both high surface area (SA) and cation exchange capacity (CEC). The expanded form has a higher SA than the natural samples, which, in turn, also have higher CEC. However, because the expanded form has lost some interlayer water during expansion by heating, cation movement in the interlayer space becomes more difficult.

Experiments performed with 200-mesh fractions of natural sample using different cations in solution $\left(\mathrm{Na}^{+}, \mathrm{K}^{+}, \mathrm{Ba}^{2+}, \mathrm{Mg}^{2+}, \mathrm{H}_{3} \mathrm{O}^{+}\right)$showed that the CEC of each ion is directly related to ionic characteristics: the higher the hydration of the interlayer cation, the higher its $\mathrm{CEC}$. For this reason, samples of natural vermiculite and others saturated with $\mathrm{H}_{3} \mathrm{O}^{+}$and with $\mathrm{Mg}^{2+}$ were employed to exchange some heavy metals $\left(\mathrm{Pb}^{2+}, \mathrm{Cu}^{2+}, \mathrm{Ni}^{2+}\right)$ in solution.

Vermiculite with $\mathrm{H}_{3} \mathrm{O}^{+}$yielded the most satisfactory results, allowing lead, nickel and copper exchange. Both natural vermiculite and those saturated with $\mathrm{Mg}^{2+}$ were very efficient in exchanging lead but not much nickel and copper. The recovery of these heavy metals from the vermiculite structure was also studied; in this case EDTA solution was employed to accelerate the exchange process. 


\section{INTRODUÇÃO}

\section{Generalidades}

A vermiculita é um argilomineral pertencente ao grupo dos filossilicatos do tipo 2:1 e pode ser encontrada tanto na fração argilosa de determinados solos, como na forma de placas de dimensões centimétricas.

As vermiculitas possuem origem secundária, resultantes, mais comumente, da alteração de micas além de piroxênios (Calle \& Suquet 1988). Este processo de alteração é denominado vermiculitização.

Segundo Robert (1968), a vermiculitização ocorre em meio neutro ou básico, em presença de soluções ricas em cátions, onde o potássio interfoliar das micas pode ser substituído por cátions mais hidratáveis como $\mathrm{Mg}^{2+} \mathrm{e} \mathrm{Ca}^{2+}$. Esse processo é reversivel e sua evolução conduz à formação de minerais hidratados com grande capacidade de troca catiônica (CTC).

Um estudo comparativo de fórmulas cristaloquímicas de diversas micas com a da vermiculita permitiu a Wey \& Le Dred (1972) observarem diferentes tendências de vermiculitização entre as micas, concluindo que as trioctaédricas são as mais susceptíveis a este tipo de transformação.

Vermiculitas verdadeiras, ou seja, aquelas formadas a partir do empilhamento de camadas só de vermiculitas, são raras na natureza, enquanto que minerais interestratificados de mica-vermiculita, regulares ou não, são muito mais freqüentes. Estes interestratificados, também conhecidos como hidrobiotitas, são comercializados com o nome de vermiculita por possuirem a propriedade de se esfoliarem quando aquecidas rapidamente a altas temperaturas. Esta propriedade de esfoliação representa comportamento característico da vermiculita, sendo por isso, largamente utilizada como simples critério de identificação deste mineral.

Gruner (1934) e Hendricks \& Jefferson (1938) já haviam detectado a presença de minerais interestratificados em seus primeiros estudos com vermiculita, e concluiram que eles representam um estágio incompleto de formação de minerais expansiveis (vermiculita e esmectita) a partir da alteração de minerais não expansiveis (micas). 
Os cátions interfoliares mais comuns encontrados em vermiculita são magnésio e cálcio nas formas hidratadas, que podem ou não serem facilmente trocados por outros íons. A facilidade deste mecanismo de troca depende de fatores relacionados com a natureza e a concentração dos cátions trocadores, como grau de hidratação, valência e raio iônico. Walker (1963 apud Grim 1968), destacou ainda que a troca catiônica em esmectitas e vermiculitas é geralmente acompanhada de mudança do eixo $\mathrm{c}$ da cela unitária.

A capacidade de troca cationica, cuja unidade de medida é dada em miliequivalentes por 100 gramas de material (meq/100g), mede a capacidade do mineral trocar alguns de seus cátions com outros do meio. No caso da vermiculita essa troca ocorre principalmente com os ions fixos no espaço interfoliar do mineral.

\section{Objetivo}

Neste trabalho estudou-se a propriedade de troca cationica em vermiculita macroscópica com o objetivo de verificar sua capacidade de retenção de metais pesados e outros elementos poluidores do meio ambiente. Este comportamento foi observado, até o momento, apenas na fração argilosa de solos. 


\section{Revisão Bibliográfica}

\subsection{Histórico}

A vermiculita foi identificada pelo mineralogista Thomas $\mathrm{H}$. Webb (1823), num depósito próximo de Worcester, Massachussetts (EUA). O termo vermiculita referese à propriedade particular do mineral de se esfoliar e se expandir em forma de vermes (em latim, vermiculare), quando rapidamente aquecida a altas temperaturas.

Outras descobertas de variedades de vermiculita receberam denominações diversas e não despertaram, como da primeira vez, qualquer interesse comercial. Somente em 1921 o mineral passou a ser explorado industrialmente e, durante muitos anos, os depósitos americanos, principalmente os da região de Carolina do Sul, foram as únicas fontes de vermiculita do mundo (Rosemburg 1972).

Em 1938 foi descoberto o depósito de Palabora situado no Transvaal (África do Sul) e considerado o mais importante do mundo ocidental (Ferraz 1971). O material deste depósito constituia, predominantemente, de minerais interestratificados de vermiculita-biotita e vermiculita-flogopita dispersos em rochas máficas e ultramáficas (Basset 1963 apud Calle \& Suquet 1988).

Atualmente as vermiculitas mais estudadas provêm de depósitos como os de Santa Olalla e Benahavis (Espanha), Praysacc (França), Malawi (África), Llano (EUA) entre outros.

No Brasil, verificou-se, no bairro de Congonhal - município de Tatuí (SP), ocorrência de material micáceo identificado, em 1949, como vermiculita (Maciel \& Guimarães 1955). Stellin Jr (1969) descreveu os principais aspectos da tecnologia e usos dessa vermiculita, e considerou, então, sua jazida como a mais importante reserva conhecida até aquele momento no Brasil. Novas jazidas foram, entretanto, sendo descobertas $e$, atualmente, as mais importantes localizam-se em Brumado (BA), Catalão (GO), Cipotânea (MG) e Paulistana (PI) (DNPM 1990). 


\subsection{Estrutura Cristalina}

Estudos sistemáticos e detalhados sobre a estrutura da vermiculita só tiveram início com Gruner (1934). Este autor definiu, pela primeira vez, a vermiculita como um mineral distinto, constituido de folhas silicáticas parecidas com as da mica ou talco, entre as quais inferiu uma dupla camada de água ocupando o espaço equivalente à camada de brucita da estrutura da clorita. Na mesma época, mas em trabalho independente, Kazantzev (1934 apud Walker 1972) também verificou que a cela unitária da vermiculita era análoga à da biotita mas de dimensões ligeiramente maiores e com potássio parcialmente substituido por oxônio e magnésio.

Mais tarde, Hendricks \& Jefferson (1938) confirmaram as conclusões gerais tiradas por Gruner, mudando alguns detalhes estruturais, como a classificação do mineral ao grupo espacial Cc-Cs ${ }^{4}$ (monoclínico antihemihedral) ao invés de $\mathrm{C}_{2 h^{6}}$. C2/c (monoclínico holohedral). Estes autores, assim como Gruner, não conseguiram explicar o motivo pelo qual a estrutura da vermiculita mantinha sempre o mesmo modelo de difração de raios $X$, mesmo após a remoção da metade da água do espaço interfoliar com aquecimento à $110^{\circ} \mathrm{C}$.

A partir dos trabalhos de Walker (1947 apud Walker 1972) e Barshad (1948) ficou claro que, no caso anterior, realmente ocorria mudança na estrutura da vermiculita, mas que era camuflada pelo rápido fenômeno de rehidratação. Notouse, então, a presença de cátions associados às moléculas de água no espaço interfoliar que podiam ser trocados por outros disponiveis no meio.

Os trabalhos que se seguiram passaram a tratar com maior interesse a grande capacidade de troca catiônica da vermiculita e sua propriedade de expansão.

Os principais estudos sobre a estrutura cristalina da vermiculita foram realizados por Grudemo (1954 apud Grim 1968), Mathieson \& Walker (1954), Walker \& Cole (1957), Mathieson (1958), Shirozu \& Bailey (1966), Walker (1972), Bailey (1984) e Calle \& Suquet (1988).

Basicamente todos concordaram que a vermiculita faz parte do grupo dos filossilicatos $2: 1$, onde cada partícula monocristalina é formada pela superposição de um certo número de camadas de estrutura e espessura bem definidas, separadas por intervalos denominados espaços interfoliares. Cada camada, por sua vez, é composta por duas folhas de tetraedros de $\left(\mathrm{SiO}_{4}\right)^{4-}$, entre as quais se liga uma folha octaédrica de composição brucitica $\left(\mathrm{Mg}_{3}(\mathrm{OH})_{6}\right)$. Enfim, o espaço 
interfoliar é ocupado por cátions hidratados que, assim como $\circ \mathrm{K}^{+}$nas micas, têm função de neutralizar as cargas elétricas geradas pelas substituições isomórficas que ocorrem na estrutura do mineral (Figura 1).

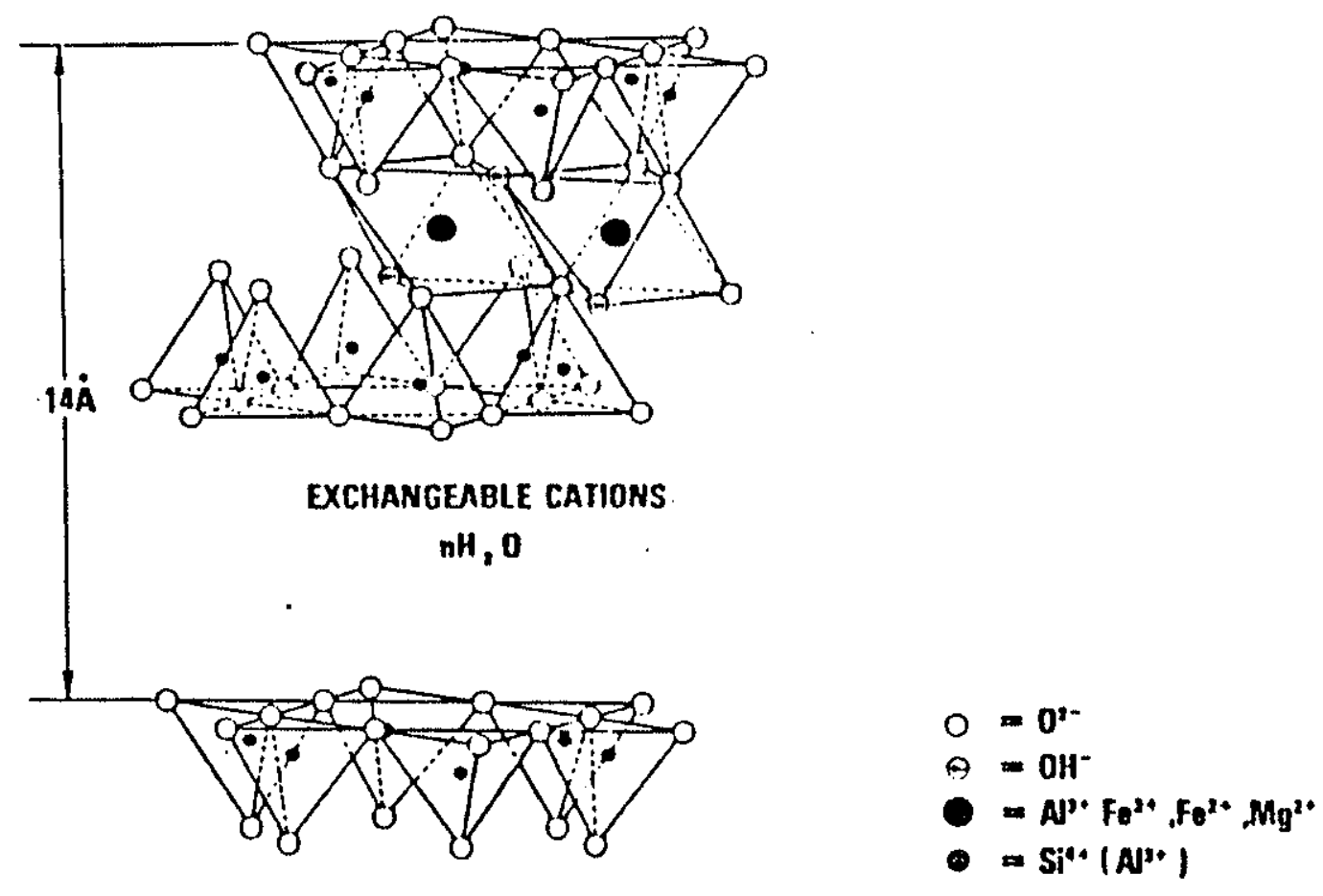

Figura 1: Desenho esquemático da estrutura da vermiculita (Pedro 1980).

Os cátions interfoliares mais comuns encontrados em vermiculitas naturais são magnésio e cálcio, e podem ser facilmente trocados por potássio, sódio, rubídio, césio, lítio e amônio, sendo alguns mais fáceis de serem substituídos que outros (Calle \& Suquet 1988). A razão de troca (facilidade de deslocamento de um ín) depende da natureza dos íons que preenchem o espaço interfoliar, além de outros fatores como:

- concentração: o aumento da concentração do cátion trocador facilita a reação de troca;

- valência: a troca tem mais efeito entre cátions de valências diferentesquanto maior a valência do ín, maior seu poder de substituição e, se já presente no mineral, mais difícil se torna seu deslocamento (Grim 1968). Com ions de mesma valência o poder de troca aumenta com o número atômico e o raio iônico. Cabe ressaltar que $\mathrm{OH}^{+}$se comporta como ion polivalente (Alloway 1990); 
- raio iônico: a capacidade de troca catiônica aumenta com a diminuição do raio iônico;

- grau de hidratação: quanto menos eletropositivo o metal, mais forte será seu grau de hidratação. Elementos fortemente eletropositivos apresentam fraca tendência de hidrólise e de formar ions complexos (Lee 1980). A energia de hidratação diminui à medida que aumenta o tamanho do íon, logo a reação de troca também diminui.

Estudos relacionados à organização da região interfoliar da vermiculita tiveram início com os trabalhos de Mathieson \& Walker (1954) e Grudemo (1954 apud Walker 1972). Dados obtidos por estes autores, através de análises de difração de raios $X$ em amostras de vermiculita, indicaram que as moléculas de água $e$ os cátions interfoliares ocupam posições bem definidas dentro deste espaçamento. Mathieson \& Walker (1954) observaram, ainda, através do método bidimensional de Fourier, que a rede formada pelas moléculas de água, na vermiculita magnesiana, consiste de duas camadas arranjadas, de modo a estabelecer coordenação octaédrica aos ions magnésio interfoliares. Neste arranjo, as moléculas de água se organizam de forma hexagonal dentro de cada folha (Figura 2).
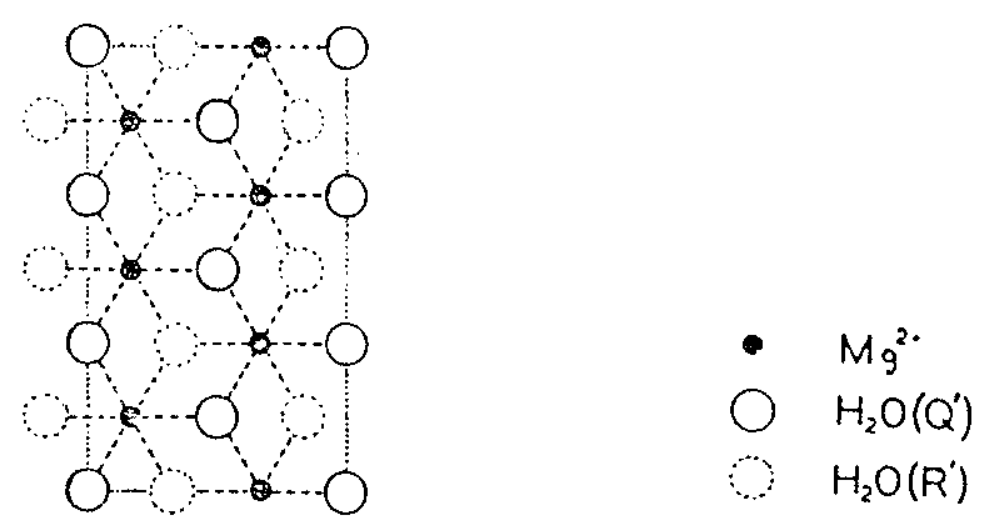

Figura 2: Desenho esquemático da superposição dos planos $R^{\prime}$ e $Q^{\prime}$, segundo - eixo cristalográfico " $\mathrm{C}$ ", dos sítios das moléculas de água em relação à posição dos cátions magnésio interfoliares de uma vermiculita magnesiana (Mathieson \& Walker 1954). 
Bradley \& Serratosa (1959) concluiram, através das análises de absorção de infravermelho, que a dupla camada de água ocupa cerca de $80 \%$ da área interfoliar de uma vermiculita magnesiana, e os íns magnésio de, aproximadamente, 10 a $15 \%$. Com o auxílio de dados químicos, Mathieson \& Walker (1954) observaram também que, aproximadamente, $2 / 3$ das posições disponiveis para as moléculas de água e 1/9 das posições dos cátions trocáveis achavam-se ocupadas. Os autores notaram, ainda, através do mapa de eletrodensidade, pequenos deslocamentos regulares das moléculas de água que produzem ligeiras distorções na estrutura da água.

A relação existente entre a rede interfoliar cátion-água e os oxigênios da camada silicática adjacentes encontra-se ilustrada na figura 3 . Nesta figura as distâncias observadas entre $\mathrm{Mg}-\mathrm{H}_{2} \mathrm{O}$ é de $1,2 \mathrm{~A}$ e entre $\mathrm{H}_{2} \mathrm{O}-\mathrm{O}$, de $2,8 \AA$.

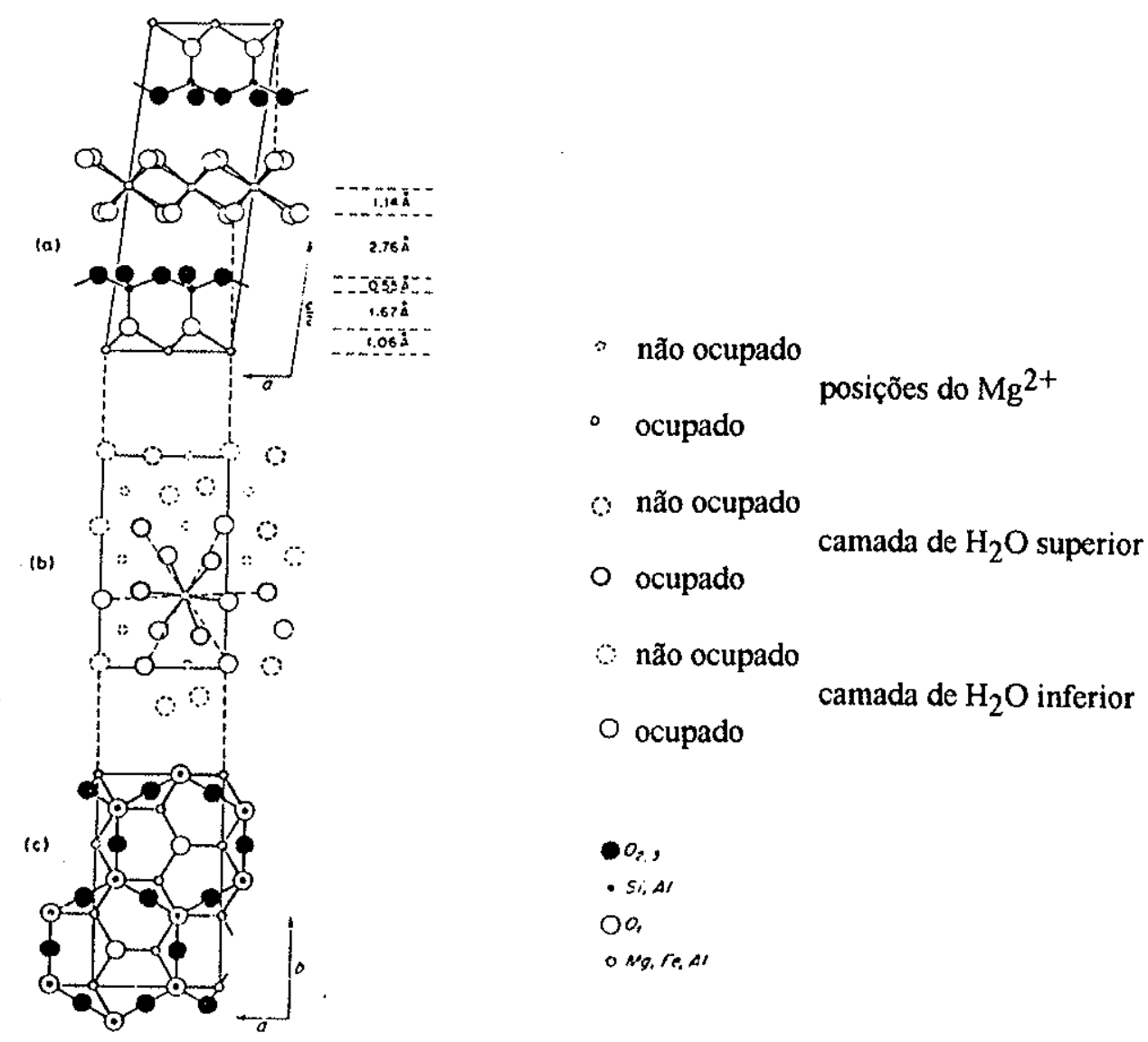

Figura 3: Estrutura cristalina de uma vermiculita magnesiana: projeção normal ao plano "ac" (a), projeção normal ao plano "ab", mostrando a região interfoliar (b) e projeção normal ao plano "ab", mostrando a folha silicática (c) (Mathieson 1958). 
A configuração final do espaço interfoliar, dada pela natureza do cátion que irá ocupá-lo e das moléculas de água que o acompanharão, pode determinar o modelo da sequência de empithamento das camadas estruturais da vermiculita (Newman 1987; Calle \& Suquet 1988). Considerando a grande variabilidade composicional da vermiculita, Calle \& Suquet (1988) indentificaram, através de análises de difração de raios $X$, mais de dez modelos de empilhamento estrutural. Cabe ressaltar ainda que o número de íons interfoliares pode variar de acordo com a densidade de carga da folha silicática.

\subsubsection{Carga Estrutural}

Carga estrutural corresponde à carga negativa derivada de substituiçōes isomórficas que ocorrem na estrutura cristalina da vermiculita. Esta carga é neutralizada, em valor equivalente, pela carga positiva dos cátions interfoliares.

A carga estrutural é comumente utilizada como um critério de diferenciação entre esmectitas e vermiculitas. O método mais comumente utilizado para a classificação destes dois grupos baseia-se na expansão estrutural do argilomineral quando saturado com glicerol ou etileno-glicol. Por exemplo, argilominerais 2:1 com carga estrutural maior que 0,6 por meia cela unitária não expandem quando tratados com glicerol, enquanto que aqueles com carga menor que 0,6 se expandem (Olis et al. 1990). O primeiro caso ocorre com vermiculitas e o segundo com esmectitas.

O método com glicerol ou etileno-glicol não permite estimar a intensidade exata da carga estrutural, por isso, recentemente, autores como Lagaly (1982), Justo et al. (1987), Häusler \& Stanjek (1988), Ghabru et al. (1989), Olis et al. (1990) e Vali \& Hesse (1992) passaram a utilizar, ou mesmo, melhorar o método elaborado por Lagaly \& Weiss (1969 apud Lagaly 1982), que consiste em tratar o filossilicato com soluções de cloretos de n-alquilamônio e observar os espaçamentos basais do mineral através de instrumentos como microscopia eletrônica de transmissão de alta resolução (HRTEM). 
Além da carga estrutural, Schofield (1949) verificou a existência de um outro tipo de carga localizada na superfície da argila; a partir desta constatação, estabeleceu os conceitos de carga permanente e carga dependente do $\mathrm{pH}$. A carga permanente não depende do $\mathrm{pH}$, pois se origina de substituições isomórficas que ocorrem nas estruturas dos argilominerais; é a carga estrutural. A carga dependente do $\mathrm{pH}$, responsável pelo fenômeno de adsorção iônica sobre a superfície das argilas, resulta da hidrólise de ligações do tipo Si-O e Al-OH rompidas ao longo da estrutura mineral. Por vezes os ions oxigênios das superfícies rompidas podem se ligar aos hidrogênios, disponíveis na solução, para formar hidroxilas. A superfície formada pela hidroxila possui comportamento anfótero (Stumm \& Morgan 1970; Eslinger \& Pevear 1988; Alloway 1990), isto é, pode reagir com $\mathrm{H}^{+}$ou $\mathrm{OH}^{-}$e originar cargas superficiais positivas e/ou negativas.

$$
\mathrm{MOH}+\mathrm{H}^{+} \Leftrightarrow \mathrm{MOH}_{2}^{+} \quad \text { e } \mathrm{MOH}+\mathrm{OH}^{-} \Leftrightarrow \mathrm{MO}^{-}+\mathrm{H}_{2} \mathrm{O}
$$

Em geral, a pHs relativamente baixos o material apresenta capacidade de troca aniônica, e a pHs altos, capacidade de troca catiônica.

A carga permanente contribui mais efetivamente nas argilas $2: 1$ sendo responsável pela elevada capacidade de troca cationica nestes minerais. A carga superficial tem somente maior expressão nas argilas do tipo 1:1.

Contradizendo os conceitos estabelecidos por Schofield (1949), Schulthess \& Huang (1990) verificaram que o termo "carga permanente" não pode ser considerado como sinônimo de comportamento independente da variação de $\mathrm{pH}$, no estudo de adsorção iônica. Para estes autores o conceito de troca iônica baseia-se na afinidade que cada tipo de superfície apresenta em adsorver determinados ions; pois, independentemente da origem do deficit de carga estrutural da vermiculita tanto os $\mathrm{H}^{+}$como os íns metálicos competem entre si pelas bases disponiveis. 


\subsection{Propriedades da Vermiculita}

\subsubsection{Comportamento Térmico}

A remoção progressiva da água adsorvida na estrutura da vermiculita com o aquecimento gradual promove o desenvolvimento de uma série contínua de fases de desidratação (Figura 4). Quando imersa em água, uma vermiculita magnesiana sofre moderada expansão que provoca aumento no seu espaçamento basal de $14,4 \AA$ para 14,8 A (Walker 1956). Iniciando o aquecimento da fase totalmente hidratada de $14,8 \AA$, a estrutura do mineral que retém aproximadamente 16 moléculas de água por cela unitária, sofre, com a remoção de água, uma pequena contração regular ao longo do eixo $\mathrm{c}$, sem provocar deslocamento lateral das camadas silicáticas. Nesta fase o espaçamento basal chega a $14,4 \AA$ e o número de moléculas de água pode decrescer para 12 ou até 9 . Quando a temperatura atinge $60^{\circ} \mathrm{C}$ ocorre uma contração abrupta da estrutura para $13,8 \AA$, desta vez provocando mudança na seqüência do empilhamento das camadas silicáticas. A geometria dos cátions e das moléculas de água remanescentes desta fase não foi precisamente estabelecida mas, segundo Grim (1968) os cátions interfoliares podem ter sido deslocados de suas posições centrais passando a ocupar os centros de octaedros menos perfeitos, que consistem de 3 moléculas de água e 3 oxigênios apicais da superfície da camada tetraédrica.

Outra contração na estrutura da vermiculita ocorre a aproximadamente $70^{\circ} \mathrm{C}$ (Walker 1960). Nesta fase o espaçamento basal é reduzido para 11,6 A devido a retirada de até 3 moléculas de água da estrutura. Por fim, a última fase de desidratação ocorre à $110^{\circ} \mathrm{C}$ quando então toda a água interfoliar é removida da estrutura e o espaçamento basal passa para 9,0 A. Nesta temperatura, entretanto, pode ocorrer, simultaneamente, a rehidratação espontânea do mineral. A remoção total e irreversivel da água interfoliar e das hidroxilas do retículo cristalino ocorre somente a temperaturas na ordem de 500 a $700^{\circ} \mathrm{C}$ (Walker 1960). 


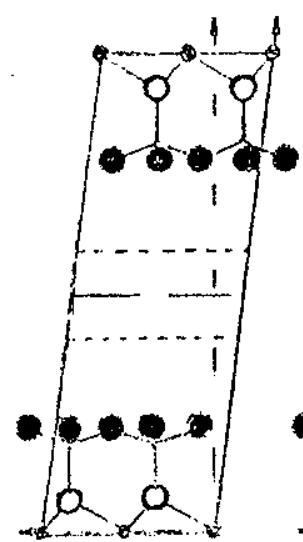

a

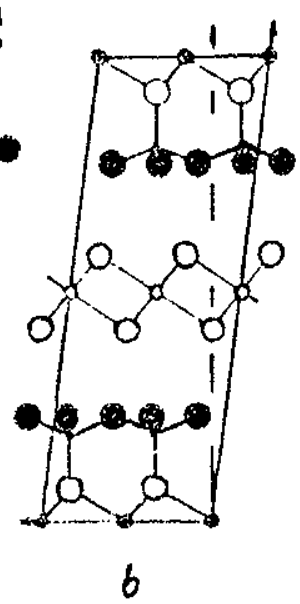

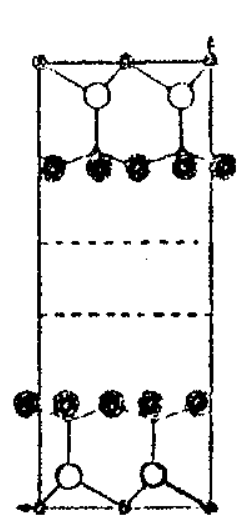

c

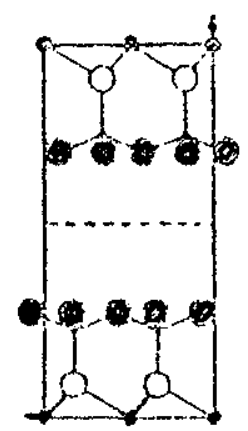

$d$

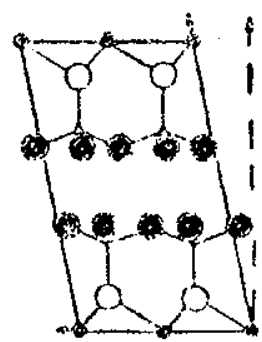

$\boldsymbol{e}$

Figura 4: Projeção normal ao plano "ac" da estrutura de uma vermiculita magnesiana mostrando as fases de hidratação: a) fase $14,8 \AA ;$ b) fase $14,4 \AA$; c) fase $13,8 \AA ;$ d) fase $11,6 \AA$ e e) fase $9,0 \AA$ (Walker 1960).

\subsubsection{Expansão}

A expansão estrutural dos filossilicatos do tipo $2: 1$ foi observada inicialmente em montmorilonitas (Hendricks \& Jefferson 1938; Méring 1946) e somente mais tarde observou-se também em vermiculitas (Barshad, 1949). A expansão, também denominada inchamento lamelar por Coelho (1986), ocorre devido à hidratação dos cátions interfoliares presentes no mineral e, dependendo da natureza destes íns (raio iônico, valência, grau de hidratação etc.) pode ocorrer diferentes niveis de expansão e até mesmo o colapso da estrutura cristalina, perpendicular ao plano das folhas silicáticas (Walker 1959). Pode desenvolver-se ainda, numa segunda etapa, inchamento por pressão osmótica originada pela diferença de concentração entre ions existentes no meio externo, que é alta, e ions do espaço interfoliar, muito baixa (Coelho 1986)

O efeito da natureza do cátion interfoliar na expansão estrutural da vermiculita foi estudada por Barshad (1950) e, mais tarde por Aylmore \& Quirk (1959), Harward et al. (1969), Jackson (1963), Coelho (1986) e Madsen \& Müller-Vonmoos (1989), entre outros. O primeiro autor observou que quando a vermiculita é saturada com cátions monovalentes de raio iônico menor que 1,3 $\AA$ (correspondente ao raio iônico do bário), sua expansão equivale à espessura de uma camada de água, 
resultando numa reflexão basal de aproximadamente $12,0 \AA$. Com cátions monovalentes de raio iônico menor que $1,3 \AA$, como o hidrogênio $(0,3 \AA)$ a expansão obtida é de duas camadas de moléculas de água $(d(002)=14,3 \AA$ ). Cátions monovalentes com raio iônico maior que 1,3 $\AA$ não levam à expansão da estrutura, enquanto que os bivalentes de raio iônico menor, porém próximo de 1,3 $\AA$ (Ex.: $\left.\mathrm{Mg}^{2+}, \mathrm{Ca}^{2+}, \mathrm{Sr}^{2+}\right)$ expandem o equivalente a duas camadas de água.

Constatou-se, portanto, que a associação cátion + molécula de água torna o raio efetivo maior que o do cátion anidro, e que o diâmetro do cátion hidratado depende da densidade de carga superficial (Tabela I).

\begin{tabular}{|c|c|c|c|c|}
\hline Cátion & R.i. $(\AA)$ & $\begin{array}{c}\delta \text { carga sup. } \\
\text { (carga/raio i.) }\end{array}$ & $\begin{array}{c}\text { Raios } \\
\text { hidratados }(\AA) \\
\end{array}$ & Hidratação \\
\hline $\mathrm{Cs}^{+}$ & 1,69 & 0,59 & 3,29 & \multirow{3}{*}{$\begin{array}{c}\text { Pouco } \\
\text { hidratado ou } \\
\text { não hidratado } \\
\end{array}$} \\
\hline $\mathrm{Rb}^{+}$ & 1,48 & 0,68 & 3,29 & \\
\hline $\mathrm{K}^{+}$ & 1,33 & 0,75 & 3,31 & \\
\hline $\mathrm{Na}^{+}$ & 0,95 & 1,05 & 3,58 & \multirow{2}{*}{$\begin{array}{c}\text { Moderadamente } \\
\text { hidratado } \\
\end{array}$} \\
\hline $\mathrm{Ba}^{2+}$ & 1,35 & 1,48 & 4,04 & \\
\hline $\mathrm{Li}^{+}$ & 0,60 & 1,70 & 3,82 & \multirow{3}{*}{$\begin{array}{c}\text { Definitivamente } \\
\text { hidratado }\end{array}$} \\
\hline $\mathrm{Sr}^{2+}$ & 1,13 & 1,78 & 4,12 & \\
\hline $\mathrm{Ca}^{2+}$ & 0,99 & 2,00 & 4,12 & \\
\hline $\mathrm{Mg}^{2+}$ & 0,66 & 3,10 & 4,28 & \multirow{3}{*}{$\begin{array}{c}\text { Fortemente } \\
\text { hidratado em } \\
\text { ions complexos }\end{array}$} \\
\hline $\mathrm{Al}^{3+}$ & 0,50 & 6,00 & & \\
\hline $\mathrm{Be}^{2+}$ & 0,31 & 6,50 & & \\
\hline
\end{tabular}

Tabela I: Niveis de hidratação dos cátions (modificado de Souza et al. 1978).

Coelho (1986) estudou o comportamento de expansão em água de vermiculitas brasileiras previamente tratadas com soluções salinas inorgânicas. $O$ autor obteve expansões máximas de até oito vezes o volume aparente inicial, com 
amostras tratadas com cloreto de lítio, cuja solução fora aquecida junto com a amostra até sua secagem. A explicação para esta expansão baseou-se nos estudos de Quirk \& Theng (1960) que sugeriram a migração do íon lítio desidratado (devido ao aquecimento no tratamento) para o interior da estrutura do filossilicato, através dos orifícios hexagonais das camadas tetraédricas, diminuindo sobremaneira o desbalanceamento elétrico desta estrutura e, consequentemente, também a CTC. Uma vez reduzida a carga elétrica, a atração eletrostática entre as camadas adjacentes da estrutura do filossilicato não impede a expansão pela entrada de água no espaço interfoliar. Neste caso, portanto, a expansão se deu pela rehidratação dos cátions $\mathrm{Li}^{+}$que são fortemente higroscópicos. $\mathrm{O}$ autor enfatizou, ainda, que o fenômeno de expansão pronunciada só ocorreu devido à diminuição do valor da carga estrutural da vermiculita para valores semelhantes aos de esmectitas, causada pelo tratamento salino.

Walker (1960) demonstrou, através de tratamento com butilamônio, que a expansão das camadas silicáticas de esmectitas e vermiculitas pode ocorrer devido à formação de complexos orgânicos que absorvem grande quantidade de $\mathrm{H}_{2} \mathrm{O}$ ao substituirem os cátions inorgânicos das posiçōes interfoliares destes minerais. $\mathrm{O}$ aumento da espessura devido à expansão pode chegar a algumas centenas de angstrons e, mesmo assim, o autor confirma haver certa coerência entre os cristais, que passam a apresentar aspecto de gel.

Um outro tipo de expansão parecido com àquela exibida pelos complexos vermiculita-butilamônio foi obtido com aminoácidos por Garret \& Walker (1961), que verificaram a crescente expansão com a diminuição de sua concentração na solução. Segundo esses autores, o processo de expansão inicia-se com a hidratação dos cátions de aminoácidos interfoliares que neutralizam a carga estrutural e, em seguida, passa a ser controlado por efeitos osmóticos.

Explicação semelhante também é dada por Van Olphen (1960) que ressalta haver o desenvolvimento de pressão osmótica numa etapa logo após a hidratação dos cátions. A pressão osmótica seria originada pela diferença entre a concentração em íons existentes no espaço interfoliar, que seria grar relação a concentração em íons do meio externo, muito menor. A tendên ca para manter o equilibrio entre as duas concentrações forçaria a entrada de áutu no espaço interfoliar e geraria grandes pressões, que por sua vez, superam as forças de atração entre as camadas 2:1 levando à expansão.

Quando aquecida rapidamente a altas temperaturas $\left(600-800^{\circ} \mathrm{C}\right)$ a vermiculita pode também esfoliar-se (Rosemburg 1972). A esfoliação é o mecanismo de separação das folhas estruturais (lâminas finas e muito numerosas) 
causada pela expansão da estrutura na direção perpendicular ao plano de clivagem basal fornecendo, ao mineral, aspecto semelhante ao de verme.

Neste caso a expansão é causada pelo súbito aquecimento, a temperaturas maiores que $300^{\circ} \mathrm{C}$, que acaba convertendo a água contida entre as camadas da vermiculita em vapor. Este vapor, para escapar, acaba pressionando e separando as camadas estruturais do filossilicato $2: 1$.

Deer et al. (1978) verificaram que se a remoção da água ocorrer vagarosamente, até mesmo à $250^{\circ} \mathrm{C}$, as vermiculitas não se expandem, uma vez que são facilmente rehidratáveis.

O aumento de volume resultante da piroexpansão pode ultrapassar 30 vezes - volume original do material (Rosemburg 1972), gerando assim, vazios responsáveis pela diminuição de sua densidade. Como conseqüência de suas propriedades químicas e principalmente físicas, a vermiculita esfoliada apresenta muitas aplicações como agregados para concreto leve, para enchimento solto (loose fill) de isolante térmico e acústico, e em horticultura.

Atualmente, os principais usos industriais da vermiculita no Brasil são: revestimento isolante térmico, para tubulações industriais; massas para conexões de tubos isolantes; argamassa, para pré-fabricação de tijolos; placas e blocos refratários isolantes; argamassa para isolantes acústicos; isolantes acústicos e térmicos, para aplicação por pistola pneumática (spray gunning); agregados leves e ultraleves; filtros para máscara de proteção para fins industriais, e substituto total ou parcial de solo agrícola ( Souza Santos 1975).

No meio industrial a principal característica que o mineral de vermiculita deve apresentar é a propriedade de esfoliação. Logo, o termo vermiculita usado na indústria não compreende apenas o mineral propriamente dito, mas sim de materiais que possam conter, também, interestratificações de mica e vermiculita.

Estudando a esfoliação de minerais interestratificados de mica-vermiculita, Justo et al. (1989) assim como Midgley \& Midgley (1960 apud Justo et al. 1989) e Couderc \& Douillet (1973) observaram que estes materiais produziam resultados de piroexpansão maiores que vermiculitas puras. Os últimos autores atribuíram este fenômeno ao choque térmico, de caráter passivo, entre as moléculas de água das camadas de vermiculita e as folhas de mica gerando uma abertura maior entre elas. Justo et al. (1989) não concordaram com a explicação anterior por não haver grande diferença entre a rigidez das lâminas de micas e de vermiculita; além disso, acrescentaram que o efeito de liberação de moléculas de água contra as folhas de mica seria o mesmo ou semelhante aos das vermiculita. Estes autores afirmam não existir uma simples explicação para a expansão destes minerais, baseados somente ao mecanismo físico de perda de água; esta deve diferir de uma amostra 
para outra, e depender da composição químico/mineralógica e perda dos grupos $\mathrm{OH}^{*}$.

A vermiculita esfoliada apresenta capacidade de troca catiônica bem inferior que a vermiculita crua, por ter eliminado a água interfoliar e parte da água estrutural (ou hidroxilas) que representam importante papel na absorção e troca dos cátions (Justo et al. 1989).

\subsubsection{Vermiculitização}

A vermiculita é um mineral secundário que pode se originar a partir da alteração de micas, mais comumente biotitas e flogopitas, através do intemperismo ou ação hidrotermal. O processo de alteração gera, muitas vezes, pseudomorfos de cristais macroscópicos de vermiculitas, mas também pode ocorrer produtos desta alteração na fração argilosa.

A vermiculita também pode se formar na região de contato entre intrusivas ácidas e rochas básicas/ultrabásicas, em cujas circunstâncias pode estar associada a minerais como coridom, apatita, serpentina, clorita ou talco (Weaver 1958; Walker 1960; Deer et al. 1978; Calle \& Suquet 1988). Calle \& Suquet (1988) e Deer et al. (1978) também destacaram a ocorrência de vermiculitas associadas a carbonatitos e mármores.

Em geral, vermiculitas macroscópicas (macrovermiculitas) são trioctaédricas. As formas dioctaédricas foram encontradas, até agora, na fração argila de solos (Souza Santos 1975).

O fenômeno de vermiculitização no meio natural tem sido amplamente estudado e muitos concordam com a seguinte equação mineralógica, representativa do contínuo processo de alteração e transformação:

$$
\begin{aligned}
& \text { mica } \longrightarrow \text { vermiculita } \\
& \text { vermiculita } \longrightarrow \text { esmectita }
\end{aligned}
$$

A reação (1), como já foi mencionada, é a mais estudada, ao passo que a (2), a qual conduz à formação de esmectitas, é menos conhecida. Esta última reação também pode gerar caulinita, como observou Toledo-Groke (1986) na evolução mineralógica dos produtos de alteração da biotita da Serra dos Carajás (PA). 
A vermiculitização de micas, no geral, provoca a diminuição da intensidade e alargamento do ângulo de difração basal do mineral, com espaçamentos basais intermediários entre 10,0 e 15,0 A; aumento da superfície interna; diminuição do conteúdo de potássio; aumento em água ou hidroxila na estrutura; diminuição na ocupação tetraédrica (devido à perda do aluminio); modificação dos teores dos cátions octaédricos (ferro, magnésio, alumínio etc); e diminuição da carga elétrica por unidade estrutural devido, principalmente, à oxidação do $\mathrm{Fe}^{2+}$ na camada octaédrica (Roy \& Romo 1957; Foster 1963; Robert \& Pedro 1966; Robert 1968; Robert \& Barshad 1972).

Em um de seus primeiros trabalhos, Barshad (1948) não considerou o conteúdo de ferro na mica originária como um fator influente no processo de vermiculitização e, mais tarde, Hoda \& Hood (1972) constataram que em determinadas micas, pobres em ferro, a diminuição da carga era superior à oxidação do ferro, isto é:

$\left[\text { folha }\left(x \mathrm{Fe}^{2+}\right)\right]^{y-} \rightarrow\left[\text { folha }\left(x \mathrm{Fe}^{3+}\right)\right]^{z-}$, onde $z<y-x$.

Neste caso a oxidação foi tratada como um processo independente da alteração.

Newman (1967 apud Wey \& Le Dred 1972) considerou, neste caso, o ganho de carga positiva (que proporcionou a diminuição da carga efetiva) devido à transformação de $\mathrm{O}^{2-} \mathrm{em} \mathrm{OH}^{-}$, situados nos vértices dos tetraedros contendo $\mathrm{Al}^{3+}$. Para algumas micas ricas em ferro, Hoda \& Hood (1972) observaram que a diminuição da carga efetiva era inferior à oxidação do ferro:

[folha $\left.\left(x \mathrm{Fe}^{2+}\right)\right]^{y-} \rightarrow\left[\text { folha }\left(x \mathrm{Fe}^{3+}\right)\right]^{z^{-}}$, onde $z>y-x$

Besson et al. (1966), Robert \& Pedro (1969) e Farmer et al. (1971) conferiram esse aumento à perda de um próton $\left(\mathrm{H}^{+}\right)$ou ao ganho de uma hidroxila $\left(\mathrm{OH}^{-}\right)$. Segundo os autores essa transformação é frequentemente acompanhada de perda de cátions octaédricos e/ou tetraédricos.

A alteração da mica implica, como foi mencionada, principalmente na substituição do $\mathrm{K}^{+}$interfoliar por um cátion hidratado. Geralmente, esta substituição é lenta e reversivel, como demonstrou Gruner (1939), através de síntese de mica$\mathrm{NH}_{4}$ a partir do tratamento de vermiculita com $\mathrm{NH}_{4} \mathrm{OH}$.

Existem vários estudos experimentais sobre a alteração de micas, e todos utilizam soluções ricas em determinados íns para promover o fenômeno de troca entre os cátions da estrutura da mica e os do meio. 
Robert (1968) utilizou biotita e a tratou com soluções normais de $\mathrm{NaCl}$ ou $\mathrm{MgCl}_{2}$ à $80^{\circ} \mathrm{C}$ e verificou que os íons com raios elevados (como o sódio) levam mais tempo, em relação aos de raio iônico menores, para penetrarem na estrutura da vermiculita.

Wey \& Le Dred (1972) classificaram as diversas micas, segundo as dificuldades crescentes de se vermiculitizarem, e concluiram serem as micas trioctaédricas magnesianas (biotita e flogopita) as mais fáceis, e as micas dioctaédricas (muscovita) e trioctaédricas litiniferas (lepidolita) as mais difíceis. Estes autores, assim como Besson et al. (1968), verificaram que a presença de flúor na estrutura das micas tende a dificultar o processo de vermiculitização, já que se comporta como $\mathrm{OH}^{-}$, com a diferença de melhor fixar os ions potássio à estrutura.

A vermiculitização da clorita foi estudada por Makumbi \& Herbillon (1972) que emergiram a amostra em soluções de $\mathrm{NaCl}$ contendo, ora $\mathrm{H}_{2} \mathrm{O}_{2}$ para obter um meio oxidante, ora $\mathrm{SO}_{3}{ }^{2-}$ para meio redutor $e$, em condiçōes alternadas (oxidante e redutor). Os autores obtiveram melhor resultado em condições alternantes.

Robert \& Barshad (1972) trataram micas di e trioctaédricas com soluções normais de $\mathrm{NaCl}$ e $\mathrm{BaCl}_{2}$, à $60^{\circ} \mathrm{C}$ para remover o potássio de suas estruturas. $\mathrm{Em}$ seguida trataram com $\mathrm{H}_{2} \mathrm{O}_{2}$ para oxidar todo $\mathrm{Fe}^{2+}$ presente. Os autores obtiveram melhor resultado com a flogopita, que se transformou em vermiculita de alta carga, isto é, com carga estrutural de 0,85 , quando normalmente apresenta 0,6 .

A alteração da flogopita com ácidos orgânicos foi realizada por Robert \& Razzague-Kirim (1974) que obtiveram destruição da flogopita a partir de tratamento com ácidos hidroxicarboxilicos (cítrico, oxálico, salicílico etc) e, formação de vermiculita hidroxialuminosa, quando tratada com outros ácidos orgânicos.

\subsubsection{Troca Catiônica}

A troca catiônica relacionada aos componentes silicáticos de fração argila do solo passou a ser conhecida em 1850, quando Thompson (1850 apud Hesse 1971) verificou que grande parte do amônio misturado no solo era retido mesmo após lixiviação com água.

No estudo de vermiculita há um crescente interesse pela propriedade de troca de cátions, uma vez que, entre os argilominerais é a que apresenta maior CTC. 
A troca catiônica corresponde ao processo reversivel onde os cátions ficam retidos na superfície de uma fase sólida, podendo ser substituidos por quantidade equivalente de outros cátions pertencentes a uma fase liquida ou, até mesmo, sólida (Grim 1968).

Os ions envolvidos na troca ligam-se à estrutura do mineral eletrostaticamente ou por covalência, sem alterar ou decompô-la (Grim 1963). A quantidade de íons adsorvidos é proporcional à área das partículas e assim sendo representa uma propriedade característica de substâncias com elevada superfície específica. A superfície específica, por sua vez, varia de acordo com a dimensão e forma do material (Wutke \& Camargo 1972), ou seja:

- dimensão: quanto menor a partícula sólida, maior a superfície específica;

forma: partículas laminadas dispõem de superfície bem maior que àquelas das partículas esféricas e cúbicas.

A principal causa da troca catiônica em vermiculita consiste na substituição isomórfica que pode ocorrer em sua estrutura gerando excesso de cargas negativas, mais precisamente, localizado sobre as camadas tetraédricas. Esta carga excedente é neutralizada pelos cátions que ocupam as posições interfoliares e estes, por sua vez, são hidratados e se encontram fracamente ligados às camadas silicáticas adjacentes, sendo, por isso, susceptíveis à troca com outros cátions.

Os íons trocáveis são mantidos, geralmente, em torno das arestas laterais das partículas de argilominerais mas, no caso específico da vermiculita e também da montmorilonita, $80 \%$ da troca ocorre nos planos basais e o restante nas superficies laterais (Souza Santos 1975). A reação de troca é muito rápida quando ocorre nas extremidades da estrutura do mineral e lenta na região interfoliar.

A eficiência do mecanismo de troca não é idêntico para todos os cátions; dependendo da força que os ligam à estrutura do mineral alguns podem ser trocados mais facilmente que outros. Em geral, admite-se que $\mathrm{Na}^{+}, \mathrm{Ca}^{2+}, \mathrm{Mg}^{2+} \mathrm{e}$ $\mathrm{K}^{+}$são trocáveis entre si, mas $\mathrm{K}^{+}, \mathrm{NH}^{4+}, \mathrm{Rb}^{+}$e $\mathrm{Cs}^{+}$não o são (Calle \& Suquet 1988). Observando que os cátions podem ainda ser agrupados, segundo uma série de facilidade de troca, Souza Santos (1975) estabeleceu a seguinte seqüência em ordem decrescente: $\mathrm{Li}^{+}, \mathrm{Na}^{+}, \mathrm{K}^{+}, \mathrm{Rb}^{+}, \mathrm{Cs}^{+}, \mathrm{Mg}^{2+}, \mathrm{Ca}^{2+}, \mathrm{Sr}^{2+}, \mathrm{Ba}^{2+}, \mathrm{H}_{3} \mathrm{O}^{+}$. Segundo Grim (1968) a facilidade de troca varia ainda com a concentração dos ions trocáveis e dos adsorvidos pelo mineral, e ainda com suas dimensões, graus de hidratação, natureza do ânion etc.

A reação de troca é estequiométrica e pode ser representada pela seguinte equação: 


\section{AMOSTRA-X $+Y^{+} \Leftrightarrow X^{+}+$AMOSTRA-Y}

Existem vários métodos para se determinar a CTC de uma argila, que podem ser encontrados em trabalhos como os de Barshad (1948), Nicot \& Facundo (1970), Hesse (1971) e Rosemburg (1972). Assim como os métodos, os resultados podem variar, mas o princípio de todos é semelhante, o qual se baseia na saturação da argila com um cátion adequado, como por exemplo $\mathrm{NH}_{4}{ }^{+}$. Os cátions que, originalmente, se encontravam no espaço interfoliar da amostra são trocados pelos íons amônio e seu excesso é eliminado através de lavagens com água e em seguida com álcool etílico. A amostra com $\mathrm{NH}_{4}{ }^{+}$é saturada com solução contendo outros cátions, como por exemplo sódio, para remover e substituir os ions amônio. A concentração destes cátions na solução lixiviante, dada em miliequivalentes $/ 100$ gramas de amostra, representa o valor da CTC do mineral. O princípio da determinação da CTC encontra-se esquematizado na figura 5 .

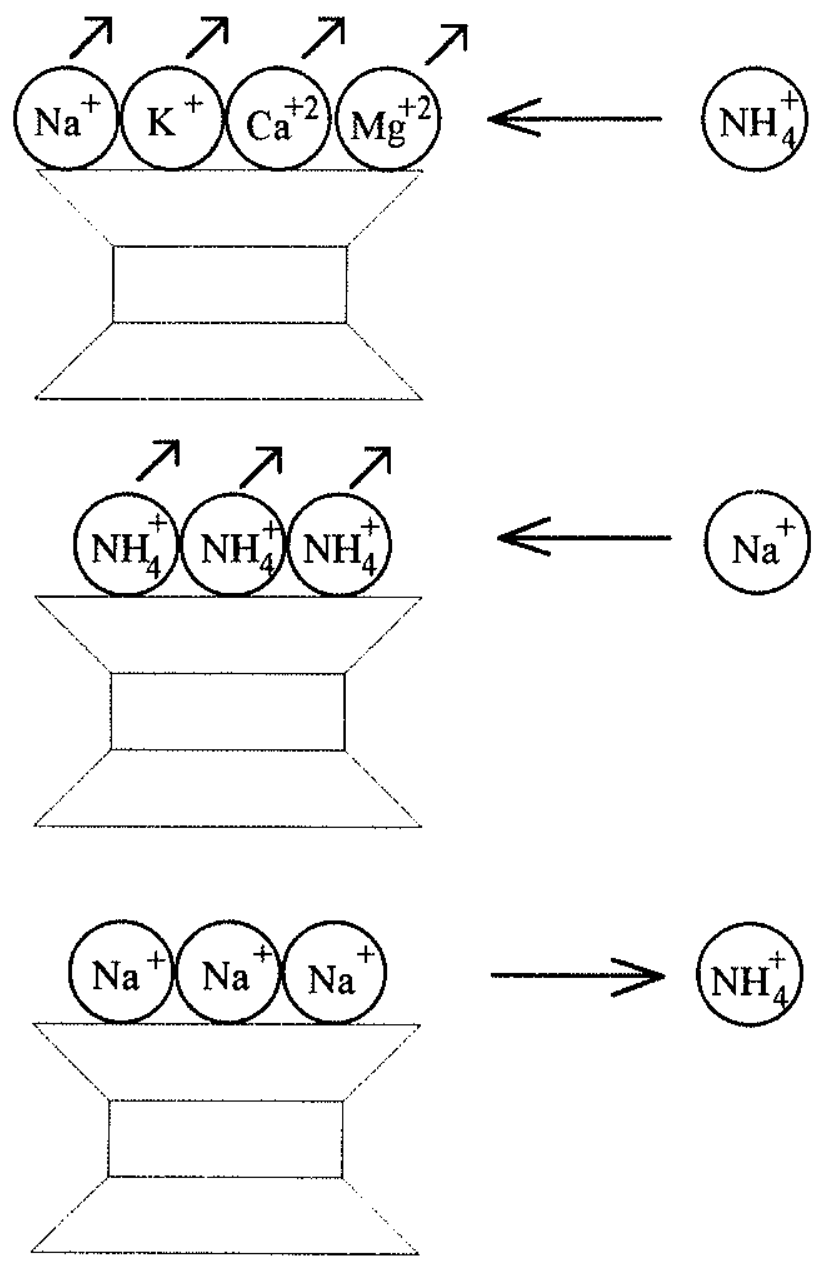

1. a amostra natural é saturada com $\mathrm{NH}_{4}^{+}$;

2. em seguida é saturada com $\mathrm{Na}^{+}$;

3. os cátions $\mathrm{Na}^{+}$substituem $\mathrm{NH}_{4}^{+}$na amostra e estes são determinados na solução.

Figura 5: Esquema das etapas envolvidas na determinação da CTC em argilominerais. 
Existem inúmeros trabalhos que investigam ou procuram aplicar em determinadas atividades a propriedade de troca cationica da vermiculita. No campo da agronomia, Salati et al. (1980), estudando os efeitos da adição de vermiculita em latossolos, verificaram aumento na retenção e no armazenamento de água nestes materiais. Mora Solis (1981) por sua vez, observou a fixação do fósforo em solos contendo considerável quantidade de vermiculita; a fixação de nitrogênio por este mineral foi observada por Stone et al. (1986); e Kinjo et al. (1987) estudaram o fenômeno, observando a adsorção de micronutrientes catiônicos na estrutura da vermiculita. Ranger et al. (1991) utilizaram a vermiculita macroscópica cominuída como mineral-teste no monitoramento da dinâmica geoquímica de coberturas pedológicas. Estes autores introduziram a macrovermiculita em sacos permeáveis que foram, por sua vez, instalados em diversos horizontes de solo; após terem sido lixiviados pelas soluções descendentes e analisadas quimicamente, as amostras contidas nos sacos caracterizaram bem os processos geoquímicos ativos em solos ácidos. Seguindo esta metodologia, Rocha \& Cerri (1992) estudaram solos de regiões de clima tropical (Amazônia) e subtropical (Londrina, PR), ambos úmidos, para acompanhamento dos processos pedológicos atuantes.

A remoção de certos elementos indesejáveis ao meio ambiente foi amplamente estudada por pesquisadores de diversas áreas, entre eles: Carlsen \& Bo (1981), que utilizaram esmectitas e caulinitas para fixação de radionuclídeos $\left(\mathrm{Sr}^{85}\right.$ e Cs$\left.{ }^{134}\right)$; Obukhovskaya (1982), que forneceu informações a respeito da adsorção de mercúrio em certos solos contendo argilominerais expansiveis; Raymahashay (1987), que fez um levantamento de trabalhos experimentais sobre a utilidade dos argilominerais no controle da poluição, chegando à conclusão de que as argilas de solo podem reter em suas estruturas metais poluidores de mananciais. Das \& Bandyopadhyay (1991), que estudaram a remoção de $\mathrm{Pb}^{2+} \mathrm{em}$ meio aquoso com amostras de macrovermiculitas; e Malla et al. (1991), que detectaram a adsorção de $\mathrm{Cu}^{2+}$ em montmorilonitas.

Cabe citar ainda, o trabalho de Alcover et al. (1973) que, além de abordarem a fixação de $\mathrm{Ni}^{2+}$ na vermiculita, definiram sua distribuição na estrutura do mineral; e Schulthess \& Huang (1990) que verificaram a adsorção de metais pesados, não especificadamente em vermiculitas, mas em montmorilonitas. 


\section{MATERIAIS E MÉTODOS}

\section{Materiais}

As amostras de vermiculita utilizadas neste trabalho provém da jazida de Massapé-Paulistana, localizada a sudeste do Estado de Piauí. Esta jazida é considerada uma das mais importantes do país (Figura 6).

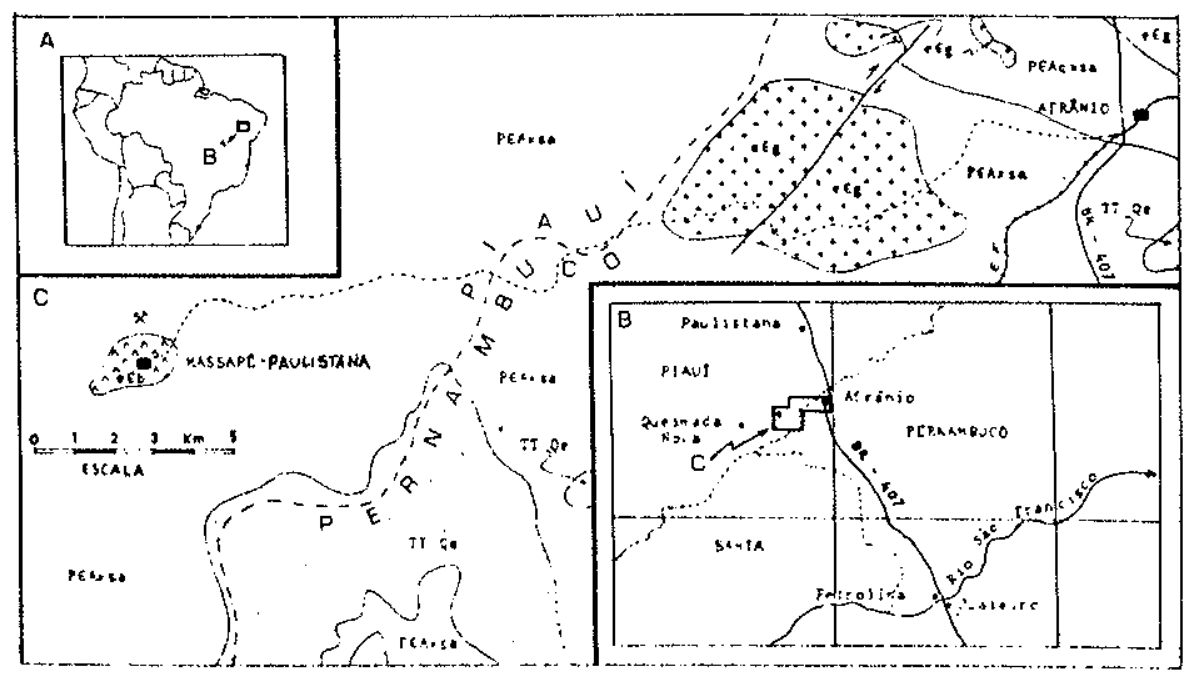

Figura 6: Localização da jazida de vermiculita de Massapé-Paulistana (PI) (Hennies \& Stellin Jr 1978).

A vermiculita de Massapé-Paulistana provém da alteração supérgena de biotitas e flogopitas associadas a rochas básicas e também aos veios pegmatóides (Hennies \& Stellin Jr 1978). No primeiro caso sua granulação apresenta-se fina e no segundo, em forma de placas centimétricas; ambas possuem cor dourada a verde-bronze.

As amostras estudadas foram cedidas pela Eucatex S/A e são classificadas comercialmente como vermiculita. A empresa a utiliza em sua forma piroexpandida para a produção de uma série diversificada de isolantes termo-acústicos e de produtos destinados ao uso agrícola. 


\section{Preparação de amostras}

As amostras utilizadas neste trabalho consistiram de macrovermiculitas cruas e piroexpandidas que passaram, inicialmente, por processos de micronização. A princípio, tentou-se utilizar o moinho de bolas de ágata para sua moagem, mas devido à dificuldade oferecida pela forma placóide das amostras, preferiu-se optar pelo tratamento em micronizador usado na fabricação de pó compacto na indústria de cosméticos.

Uma vez micronizadas, as amostras de vermiculita foram selecionadas granulometricamente por peneiramento a seco. As amostras cruas na fração de 200 mesh $(<0,074 \mathrm{~mm}$ ) foram catalogadas como $\mathrm{M}-1$; as de granulometria de 0,5 a $1,0 \mathrm{~mm}$, de $\mathrm{M}-2 \mathrm{e}$, finalmente, as formas piroexpandidas finas $(<0,074 \mathrm{~mm}) \mathrm{e}$ grossas (entre 1,0 e 6,0 mm), de M-3 e M-4, respectivamente.

\section{Métodos}

Os trabalhos laboratoriais obedeceram aos rigores exigidos na obtenção de dados analíticos (químico-físicos) e mineralógicos, e seus parâmetros foram devidamente controlados.

As identificações mineralógicas foram efetuadas por difratômetro de raios $X$ da "VEB Carl Zeiss Jena - URD-6", com registro gráfico, utilizando radiação K- $\alpha$ do cobre, com velocidade de varredura de $10(2 \theta)$ por minuto. Os respectivos difratogramas de raios $X$ também foram tratados em programas computacionais AJU adaptados por Carvalho \& Atencio (1993).

As amostras foram caracterizadas também através de micrografias eletrônicas, análises termogravimétricas e termodiferenciais. As micrografias eletrônicas foram obtidas através de microscópio eletrônico "Hitachi HU-12A" e as análises termogravimétricas e termodiferenciais por aparelho "Mettler TA-1".

As medidas de $\mathrm{pH}$ foram efetuadas em potenciômetro da "Metrohm" com eletrodo combinado de vidro modelos EA-121 e E-512, respectivamente. As leituras foram efetuadas após calibrações com tampões 4.0 e 7.0 .

Nas determinações de superfícies específicas utilizou-se o método BET e outro baseado nos princípios do método de BOWER \& GSCHWEND (1952). 
Os elementos químicos determinados para as amostras estudadas foram analisados quantitativamente pelos métodos analíticos citados na tabela II.

\begin{tabular}{|c|l|}
\hline ELEMENTO & \multicolumn{1}{c|}{ MÉTODO ANALÍTICO } \\
\hline $\mathrm{Ca}, \mathrm{Mg}, \mathrm{Al}$ & volumétrico (EDTA) \\
\hline $\mathrm{Fe}$ & volumétrico $\left(\mathrm{VO}^{3-} \mathrm{N}_{2} \mathrm{O}_{4}^{2-}\right)$ \\
\hline $\mathrm{Fe}$ & volumétrico $\left(\mathrm{Cr}_{2} \mathrm{O}_{7}^{2-}\right)$ \\
\hline $\mathrm{Si}, \mathrm{H}_{2} \mathrm{O}^{-}, \mathrm{H}_{2} \mathrm{O}^{+}$ & gravimétrico \\
\hline $\mathrm{K}, \mathrm{Na}, \mathrm{Li}$ & fotometria de chama \\
\hline $\mathrm{Mn}, \mathrm{Ti}, \mathrm{P}_{2} \mathrm{O}_{3}$ & colorimétrico \\
\hline $\mathrm{Cu}, \mathrm{Ni}, \mathrm{Ba}, \mathrm{Sr}$ & espectrofotometria de absorção atômica \\
\hline
\end{tabular}

Tabela II: Métodos analíticos utilizados para a análise química da vermiculita de Massapé-Paulistana (PI).

Os teores dos elementos menores foram determinados por espectofotômetro de absorção atômica da "Varian Techtron - 1200" e da "CG-AA 7000 BC".

Para as determinações de potássio e sódio utilizou-se fotômetro de chama da "Micronal - B262", e as análises por colorimetria foram determinadas por espectrofotômetro da "Micronal - B295II".

Os banhos termostatizados foram das marcas "Fanem 112" e "Eberbach". 


\section{CARACTERIZAÇÃO DOS MATERIAIS}

\section{Análise Mineralógica por Difração de raios $X(D R X)$}

Para a identificação mineralógica foram efetuados difratogramas de raios $X$ das vermiculitas crua (M-1) e expandida (M-3) na forma natural, pré-tratadas com etileno-glicol e previamente aquecidas à temperaturas superiores a $700^{\circ} \mathrm{C}$.

Para a obtenção dos difratogramas das amostras na forma natural, elas foram mantidas suspensas em água destilada sobre lâminas de vidro, até a completa secagem. Este método de preparo permite que haja melhor distribuição das placas do filossilicato segundo a posição basal durante a sua deposição sobre a superfície da lâmina.

No tratamento com etileno-glicol as amostras orientadas nas lâminas de vidro foram expostas em uma atmosfera de vapores de etileno-glicol dentro de um dessecador por 48 horas. $O$ tratamento com etileno - glicol distingue vermiculitas e cloritas de esmectitas, já que as reflexões basais das primeiras não se alteram como das últimas, que tem seu $\mathrm{d}(001)$ aumentado de $14,0 \AA$ para $17,0 \AA$ (Bailey 1984).

No processo de aquecimento a amostra $\mathrm{M}-1$ foi introduzida em cadinho de platina, e aquecida a $750^{\circ} \mathrm{C}$ por 4 horas. Em seguida foi prensada a seco em suporte de alumínio, próprio para a leitura no difratômetro. Para a vermiculita expandida (M-3) foi suficiente o aquecimento à $550^{\circ} \mathrm{C}$ por 5 horas na própria lâmina de vidro. Este ensaio permitiu, por sua vez, distinguir vermiculita e esmectita de clorita, pois enquanto as duas primeiras perdem toda a água interfoliar e passam a apresentar reflexão basal de $10,0 \AA$, as cloritas mantém o seu à $14,0 \AA$.

\section{RESULTADOS}

A tabela III apresenta a reflexão basal d(002) obtida pelos materiais após cada um dos ensaios. 


\begin{tabular}{|c|c|c|c|}
\hline AMOSTRA & NATURAL & ETILENO-GLICOL & AQUECIMENTO \\
\hline \hline M-1 & $14,0 \AA$ & $14,0 \AA$ & $9,9 \AA\left(700^{\circ} \mathrm{C} / 4 \mathrm{~h}\right)$ \\
\hline$M-3$ & $15,1 \AA$ & $15,8 \AA$ & $9,8 \AA\left(550^{\circ} \mathrm{C} / 5 \mathrm{~h}\right)$ \\
\hline
\end{tabular}

Tabela III: Reflexão basal d(002) das vermiculitas crua (M-1) e expandida (M-3) de Massapé-Paulistana, antes e após tratamentos com etileno-glicol e aquecimento.

O difratograma da vermiculita crua ( $M-1)$, sem tratamento, exibe, além da reflexão d(002) de 14,0 A típico da vermiculita, uma reflexão de 12,3 $\AA$ indicando interestratificação regular 1:1 de mica-vermiculita, e outra de 10,3 $\AA$, típico da mica (Figura 7). Tanto o mineral interestratificado quanto a mica encontram-se disseminadas nas amostras em proporções baixas, dificultando as suas separações mesmo através de separador magnético.

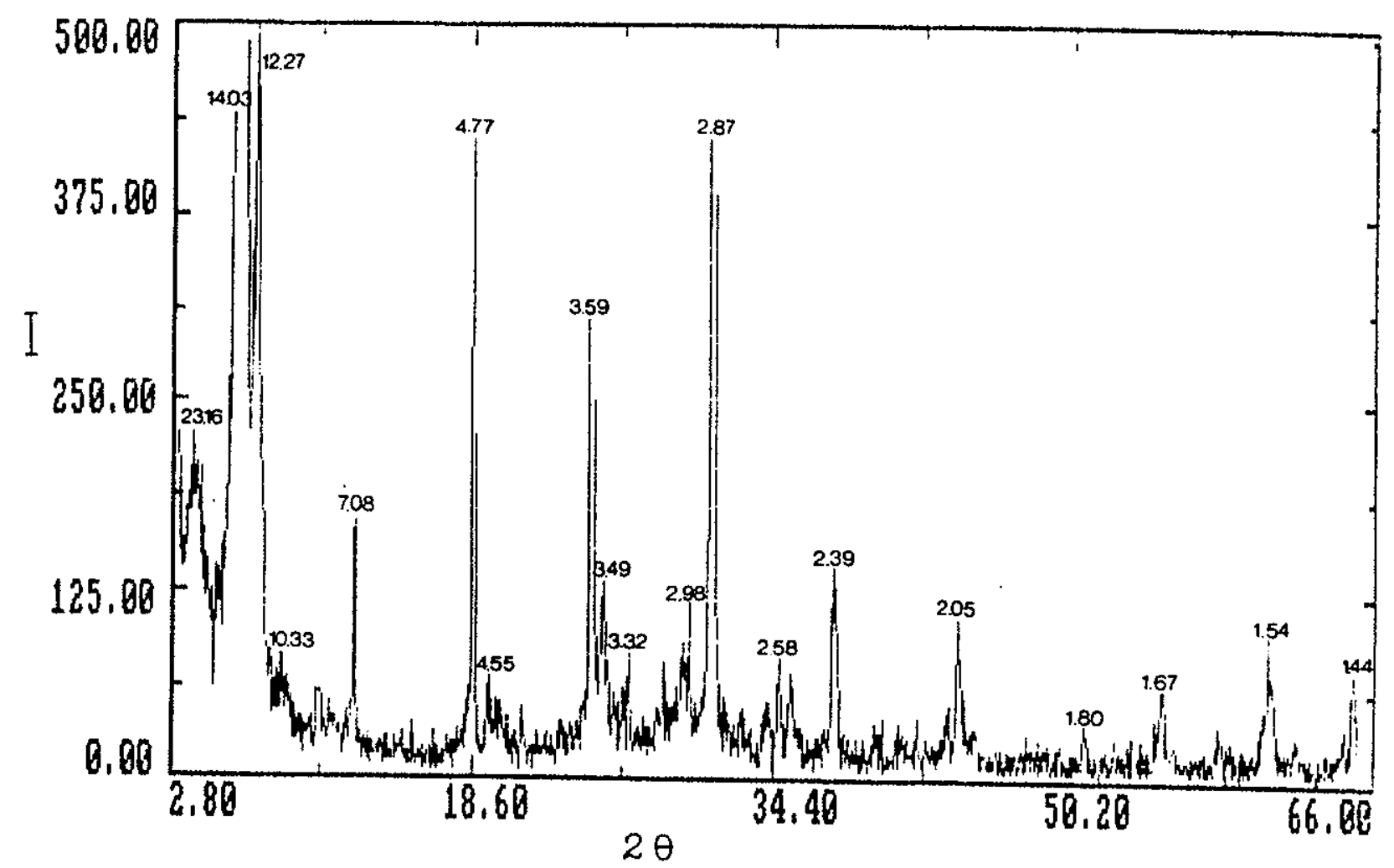

Figura 7: Difratograma de raios $X$ da amostra natural $M-1$. 
$\mathrm{Na}$ análise mineralógica da amostra expandida (M-3) não se verifica grandes variações nos picos de reflexões em relação à amostra crua.

Os difratogramas obtidos a partir do tratamento com etileno-glicol revelam uma ligeira expansão de 14,4 para 15,8 Å na estrutura de $M-3$. Tal fenômeno pode estar relacionado a alguma mudança ocorrida na amostra durante o processo de piroexpansão, pois o mesmo não foi observado em $\mathrm{M}-1$, que manteve 0 espaçamento basal, antes e após da glicolagem, a 14,0 A

Até esta etapa pode-se descartar a possibilidade da presença de esmectitas, já que não se observa reflexão basal de $17,0 \AA$. Continuam, no entanto, a prevalecer as características difratométricas dos grupos da clorita e da vermiculita.

Os difratogramas obtidos a partir do aquecimento das amostras estudadas, finalmente, indicam presença de vermiculita e ausência de clorita, já que suas reflexões basais passaram de 14,0 para $9,9 \AA$ (Figura 8 ).

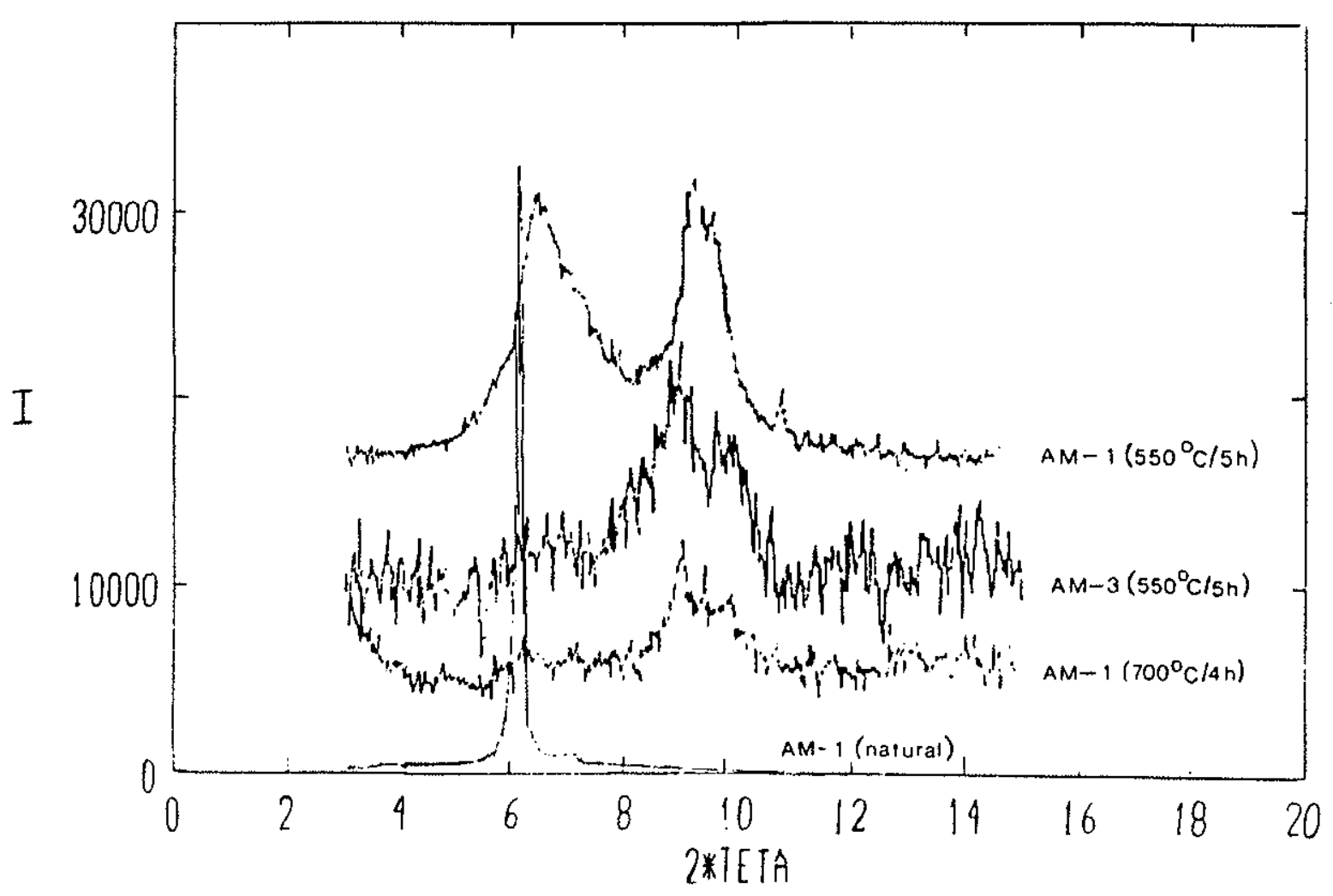

Figura 8: Difratograma de raios $\mathrm{X}$ das amostras aquecidas. 
Cabe ressaltar que o processo de aquecimento para ambas as amostras variou de acordo com a facilidade de rehidratação. A técnica de aquecer a lâmina contendo a amostra à $550^{\circ} \mathrm{C}$ por 5 horas pode ser aplicada somente à vermiculita expandida, pois sob as mesmas condições a amostra crua rehidrata-se facilmente. Após vários testes, constatou-se que a desidratação irreversivel deste mineral só ocorre à $750^{\circ} \mathrm{C}$ por 4 horas, quando então sua estrutura entra em colapso e se inicia a etapa de formação da enstatita (Figura 9).

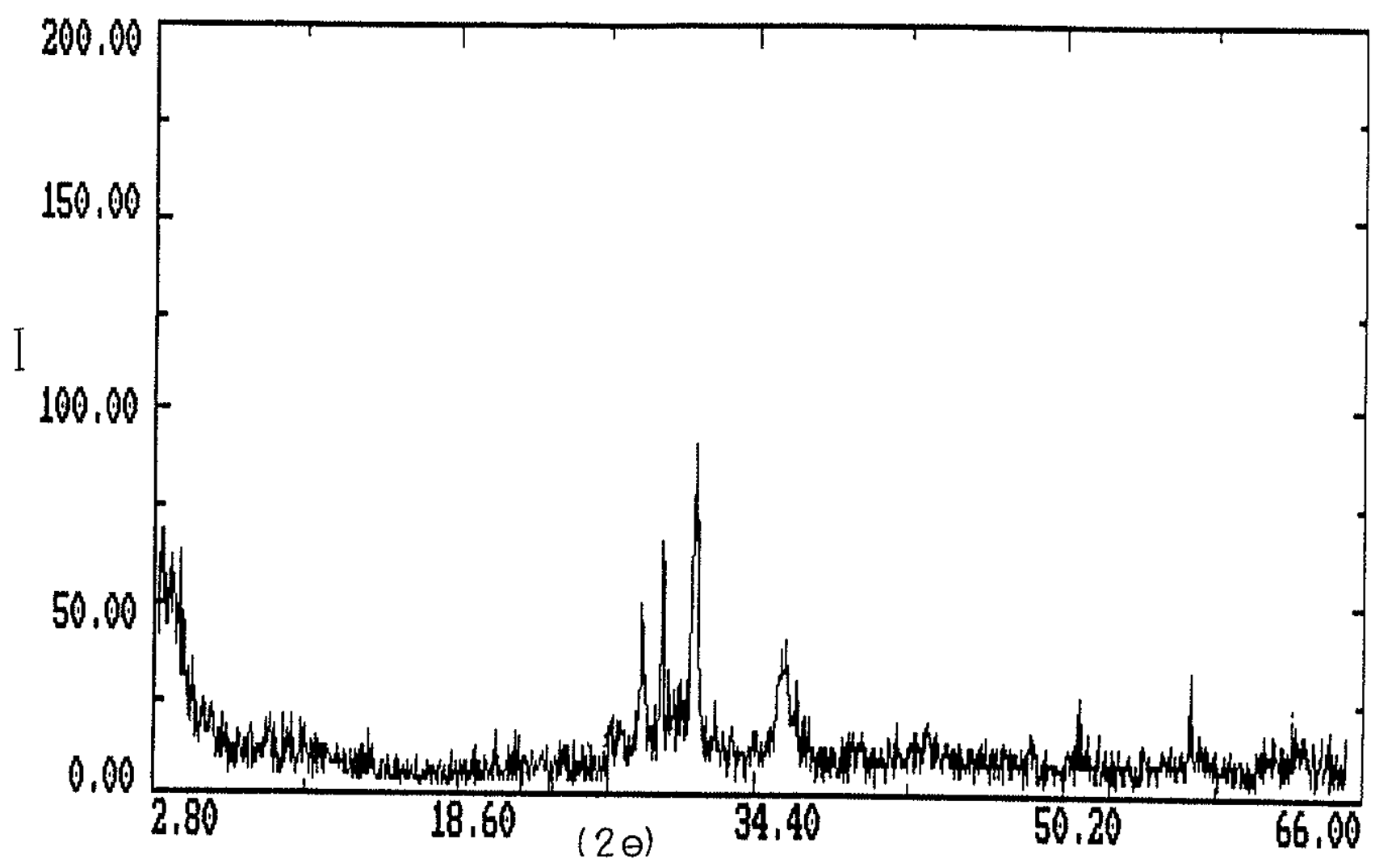

Figura 9: Difratograma de raios $X$ da enstatita formada a partir do colapso da estrutura da vermiculita de Massapé-Paulistana. 


\section{Análises Termodiferencial (ATD) e Termogravimétrica (ATG)}

Para a análise termodiferencial das amostras de vermiculita crua (M-1 e M-2) e expandida grossa (M-4) utilizou-se o método denominado DSC (Differential Scanning Calorimetry) que mede a diferença de calor emitida por correntes elétricas geradas pelas amostras e por um material-padrão inerte, quando submetidos à mesma temperatura.

Os respectivos termogramas foram gerados por dois métodos:

METTLER GRAPHWARE TA 72.5, com registro colorido; neste método a detecção dos limites de temperatura tem de ser feito manualmente.

METTLER PROCESSOR TC-11, com registro monocromático (preto e branco) e comando automático para detecção de limites de temperatura.

Ambos os métodos registraram de forma eficiente os efeitos térmicos sofridos pelas amostras, revelando suas fases de desidratação quando submetidas ao aquecimento progressivo adequado.

As análises das curvas termogravimétricas e termoponderadas também foram determinadas pelos métodos acima. Todos os ensaios foram realizados em atmosfera de $\mathrm{N}_{2}$.

\section{RESULTADOS}

Os dados obtidos pelo DSC encontram-se resumidos na tabela IV. Os respectivos termogramas, na versão METTLER TA 72.5 encontram-se nas figuras 10 a 12 . 


\begin{tabular}{|c|c|c|c|c|}
\cline { 2 - 5 } \multicolumn{1}{c|}{} & \multicolumn{4}{c|}{ PICOS ENDOTÉRMICOS (') } \\
\hline AMOSTRA & METTLER TA 72.5 & \multicolumn{2}{c|}{ METTLER TC-11 } \\
\hline M-1 & 115,7 & 218,5 & 116,7 & 219,9 \\
\hline M-2 & 92,6 & 213,9 & 92,6 & 212,9 \\
\hline M-4 & 81,8 & 196,0 & 81,9 & 196,0 \\
\hline
\end{tabular}

Tabela IV: Principais picos endotérmicos da vermiculita de MassapéPaulistana obtidos pelos métodos METTLER TA 72.5 e TC-11.

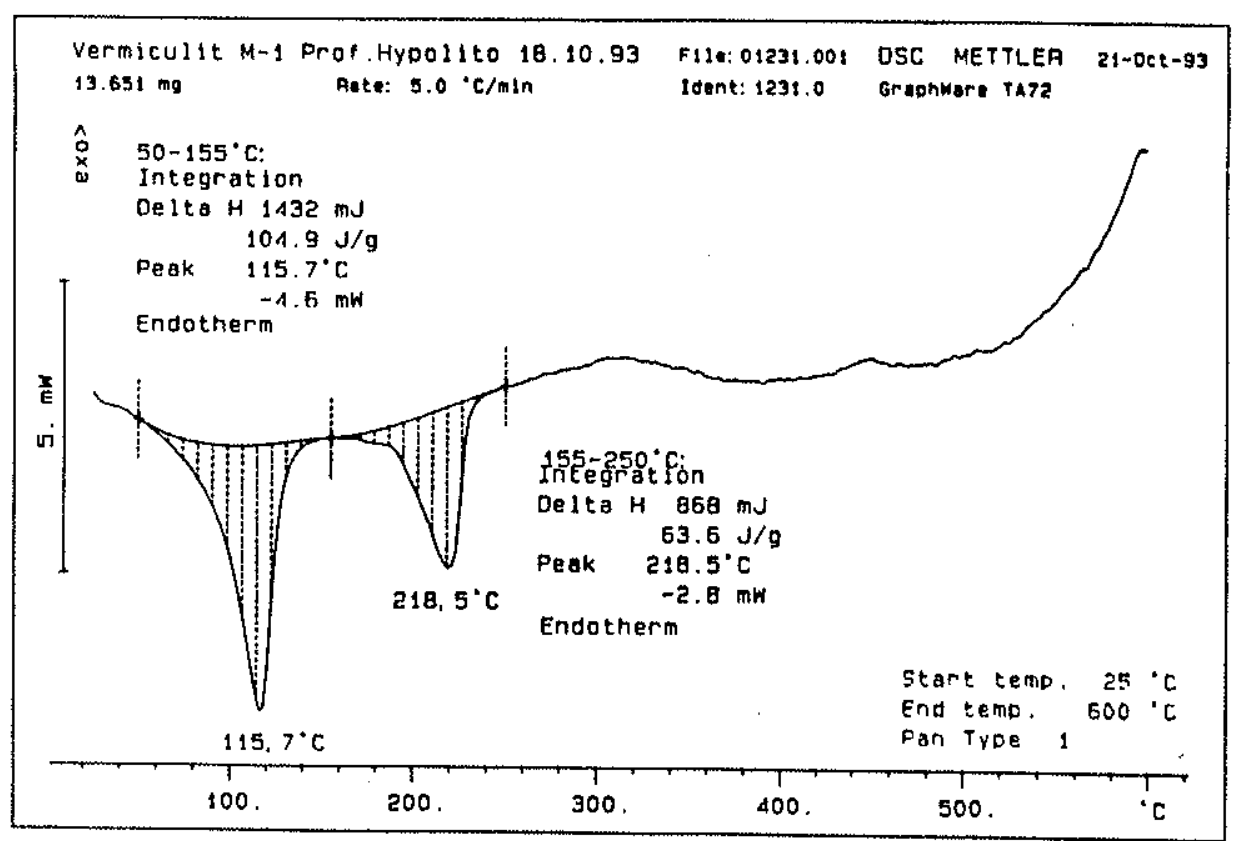

Figura 10: Curvas termodiferenciais (versão Mettler TA 72.5) da amostra M-1. 


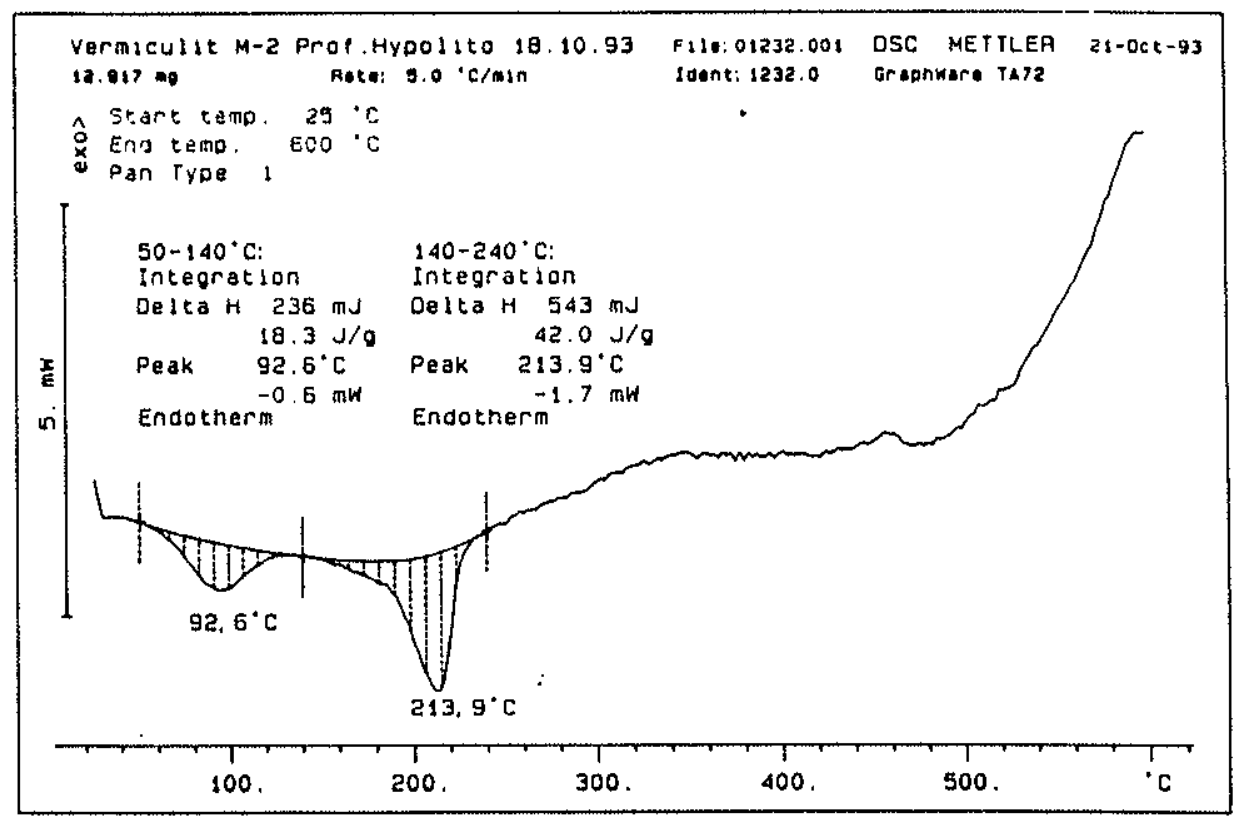

Figura 11: Curvas termodiferenciais (versão Mettler TA 72.5) da amostra M-2.

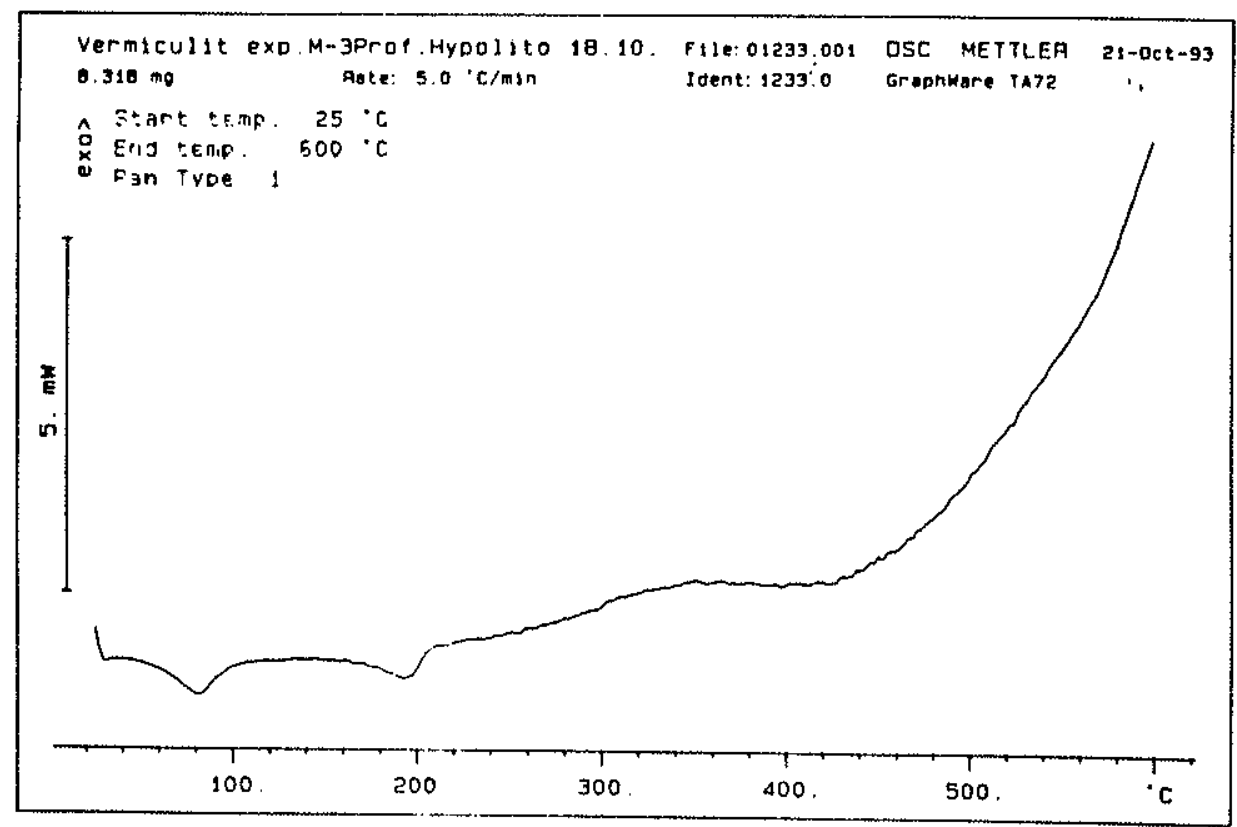

Figura 12: Curvas termodiferenciais (versão Mettler TA 72.5) da amostra M-4. 
Todas as amostras analisadas mostram dois picos endotérmicos que correspondem respectivamente à perda inicial das águas adsorvidas na estrutura e àquelas coordenadas pelos cátions interfoliares. Nesta transformação endotérmica as amostras, originalmente com duas folhas de hidratos, passam para uma só e desta se tornam anidras.

A pequena intensidade de alguns picos ocorre devido ao baixo teor de água disponivel na estrutura. Isto se verifica no primeiro pico $\left(92,6^{\circ} \mathrm{C}\right)$ da amostra $\mathrm{M}-2$ em comparação com o da $\mathrm{M}-1\left(115,7^{\circ} \mathrm{C}\right)$, que é bem mais intenso devido à maior superficie específica oferecida e que aumenta a adsorção de água em sua estrutura. Os picos endotérmicos da amostra expandida (M-4) em relação aos demais são mais tênues e quase não se destacam; isto se deve à perda parcial de água ocorrida no processo de piroexpansão.

As curvas de ATD possuem picos endotérmicos abaixo daqueles que se referem à vermiculita magnesiana: $150-200^{\circ} \mathrm{C}, 250-275^{\circ} \mathrm{C} ; 140-230^{\circ} \mathrm{C}$ (Barshad 1950; Justo et al. 1987; Justo et al. 1989). Esta diferença pode ser atribuída à heterogeneidade da população catiônica que ocupa o espaço interfoliar das amostras estudadas que, consequentemente, apresenta também grau de hidratação diferente.

O comportamento térmico obtido para as amostras estudadas é típico de filossilicatos expansiveis e a variação de intensidade dos picos que ocorreram de um material para outro foi devido ao tratamento prévio recebidos. A partir daí verifica-se que a vermiculita $M-1$ apresenta maior teor de água adsorvida em sua estrutura, em comparação com a mesma amostra não cominuida (M-2). A vermiculita expandida, como era de se esperar, apresenta menos moléculas de água em sua estrutura.

As curvas termogravimétricas (TG) e as termoponderadas diferenciais (DTG) das amostras M-1, M-2 e M-4 encontram-se ilustradas nas figuras 13 a 15 . 


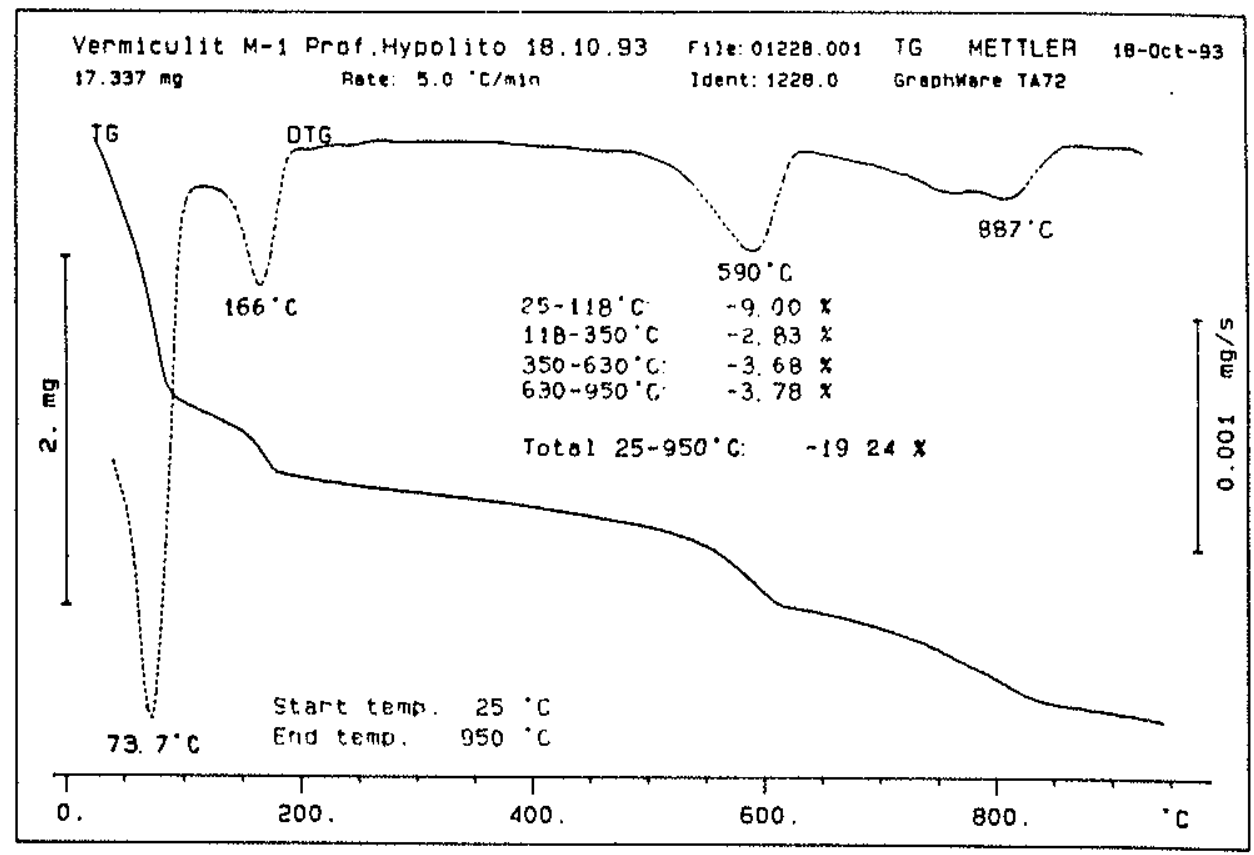

Figura 13: Curvas termogravimétrica (TG) e termoponderada (DTG) na versão Mettler TA 72.5 da amostra M-1.

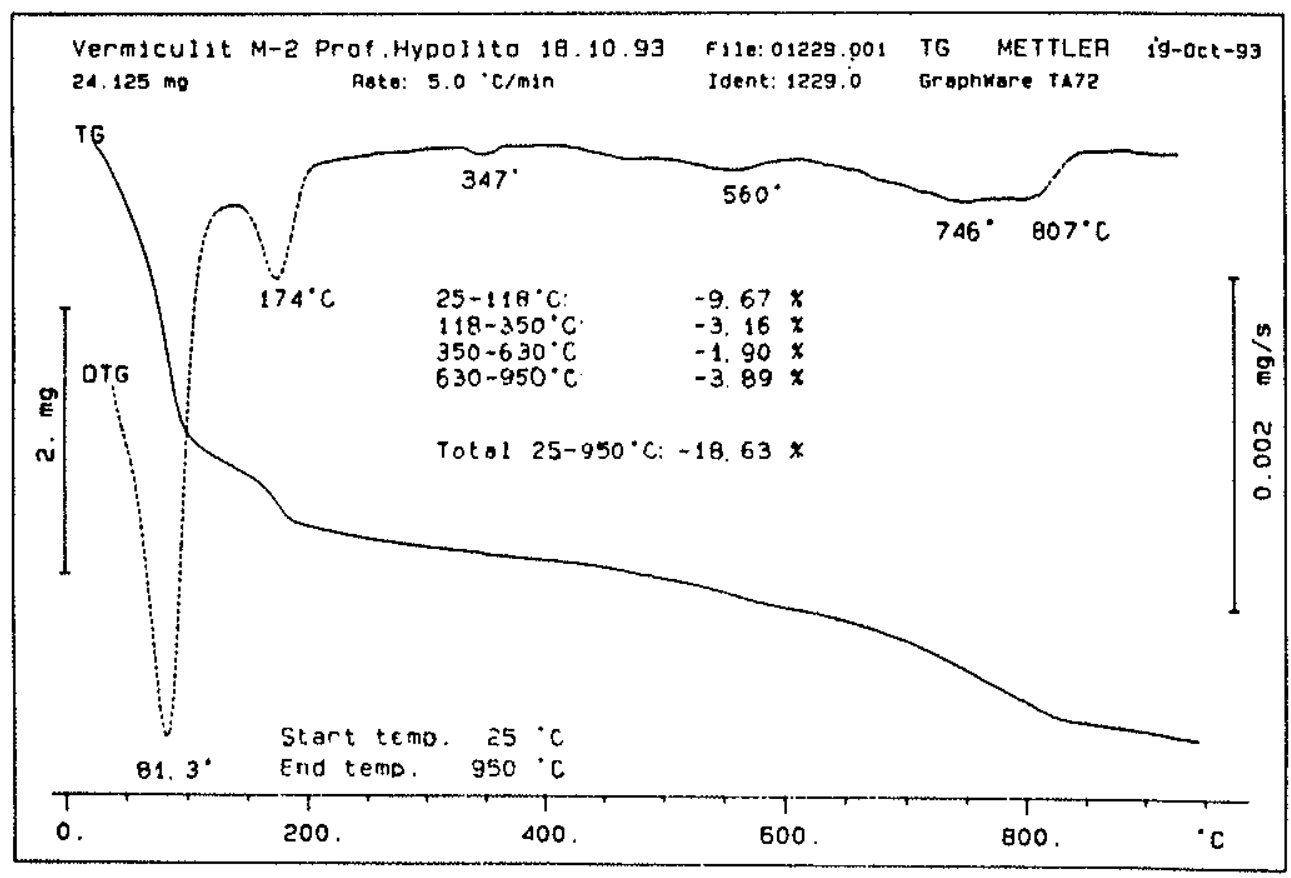

Figura 14: Curvas termogravimétrica (TG) e termoponderada (DTG) na versão Mettler TA 72.5 da amostra M-2. 


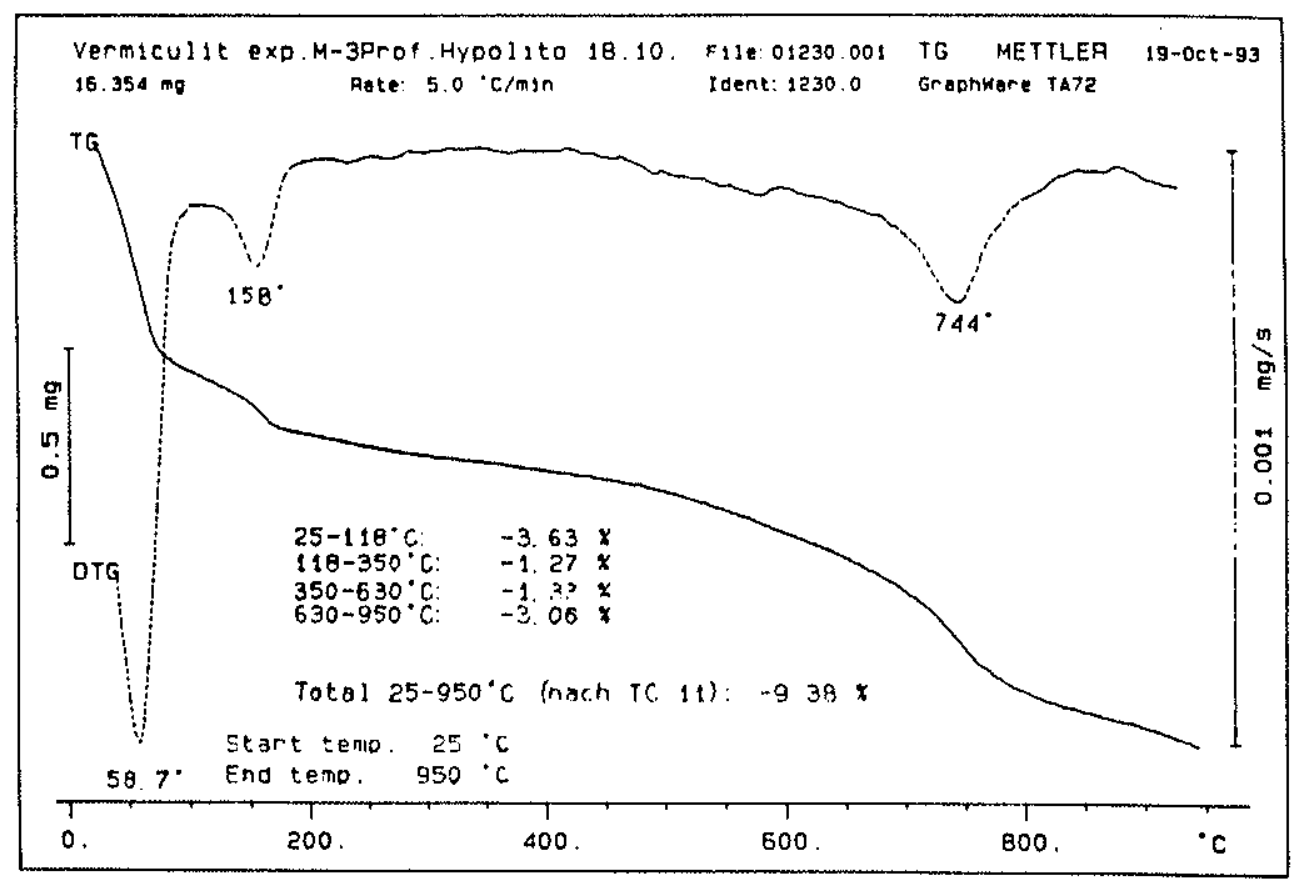

Figura 15: Curvas termogravimétrica (TG) e termoponderada (DTG) na versão Mettler TA 72.5 da amostra M-4.

A TG das três amostras são similares e apresentam perda de massa entre os seguintes intervalos de temperatura: $25-118^{\circ} \mathrm{C}, 118-350^{\circ} \mathrm{C}, 350-630^{\circ} \mathrm{C}$ e 630 $950^{\circ} \mathrm{C}$. Verifica-se que a amostra cominuida (M-1) produz curvas bem mais definidas que as demais, devido à menor granulometria; a amostra expandida (M4), por sua vez, apresenta curvas mais tênues, por perder menos peso, decorrente da piroexpansão (Figura 16).

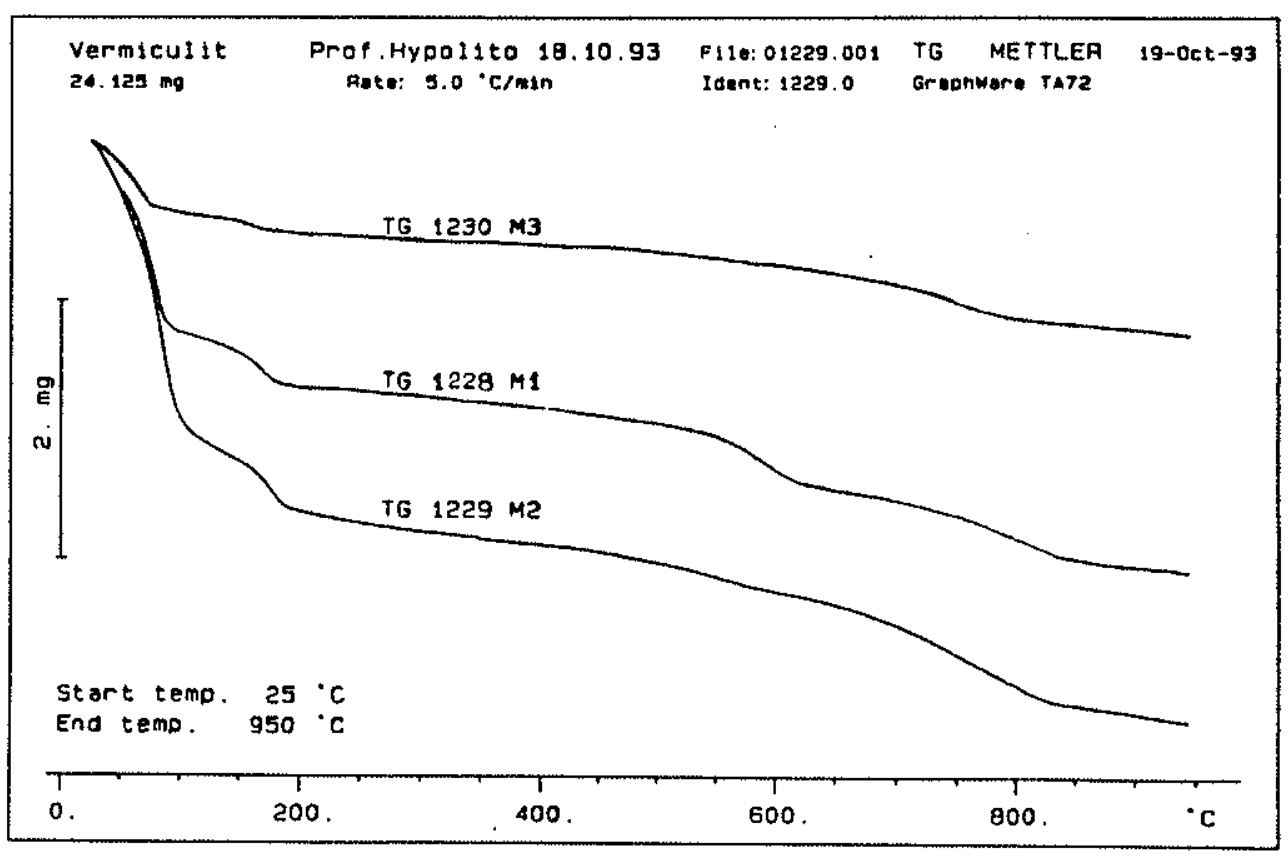

Figura 16: Gráfico de comparação entre as curvas termogravimétricas das amostras $M-1, M-2$ e $M-4$. 
O intervalo de $25-118^{\circ} \mathrm{C}$ corresponde à perda parcial de água livre contida nas amostras e àquela retida entre as suas camadas; neste caso, a parte remanescente, que corresponde, principalmente, às águas coordenadas por cátions na região interfoliar são totalmente elimidas à $118-350^{\circ} \mathrm{C}$. Segundo Grim (1963) no intervalo de temperatura correspondente à perda de água adsorvida $\left(100-200^{\circ} \mathrm{C}\right)$, uma montmorilonita cálcica apresenta dois picos endotérmicos; a vermiculita de Massapé-Paulistana apresenta dois picos endotérmicos, respectivamente à 74 e $166^{\circ} \mathrm{C}$ na amostra $\mathrm{M}-1$, à 81 e $174^{\circ} \mathrm{C}$ em M-2 e, finalmente, à 59 e $158^{\circ} \mathrm{C}$ em M-4.

Nas temperaturas entre $350-630^{\circ} \mathrm{C}$ ocorre perda das hidroxilas do retículo cristalino. Grim (1963) ressalta que num filossilicato expansível rico em ferro, o pico desta etapa ocorre, aproximadamente à $500^{\circ} \mathrm{C}$; naqueles sem ferro, ocorre à $700^{\circ} \mathrm{C}$ e nos casos intermediários dão picos em posição intermediária, assim como ocorreu na amostra $\mathrm{M}-1$ estudada (pico endotérmico à $590^{\circ} \mathrm{C}$ ). Quando o aquecimento sobe para $630-950^{\circ} \mathrm{C}$, a perda total de hidroxilas causa colapso da estrutura cristalina da vermiculita $e$, consequentemente, desaparece sua propriedade de expansäo / retração.

As curvas termoponderadas diferenciais são derivadas das curvas termogravimétricas e indicam as temperaturas em que ocorrem perdas de peso das amostras. A porcentagem total de teor de água liberado da estrutura é maior para $M-1(-19,24 \%)$, em seguida para $M-2(-18,63 \%)$ e por último para $M-4(-9,38 \%)$.

Os dados obtidos confirmam a influência das caracterísitcas físicas do mineral (granulometria e esfoliação de placas) na retenção de moléculas de água na estrutura. Novamente, verifica-se maior perda de água na amostra $M-1$ e menor em $M-4$, pelos mesmos motivos já mencionados para os ensaios de ATD. 


\section{Microscopia Eletrônica}

As micrografias eletrônicas de transmissão das amostras $M-1, M-2$ e $M-4$ (Figuras 17, 18 e 19 respectivamente), mostram, de modo geral, hábito cristalino semelhante ao da mica, constituído por agregados de placas finas e contornos mal definidos (principalmente as amostras cominuídas) e de espessuras variáveis.

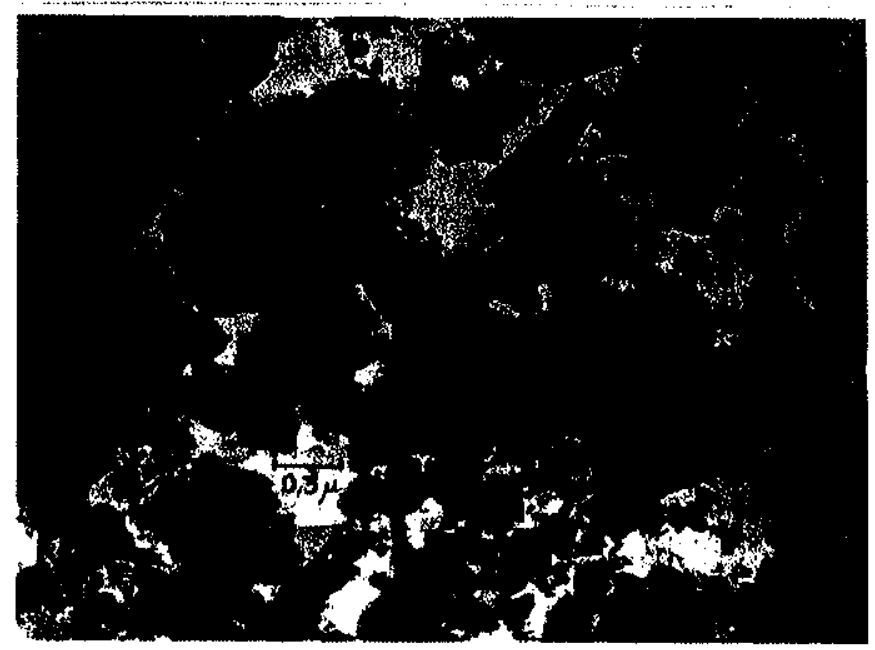

Figura 17: Micrografia eletrônica de transmissão da amostra M-1.

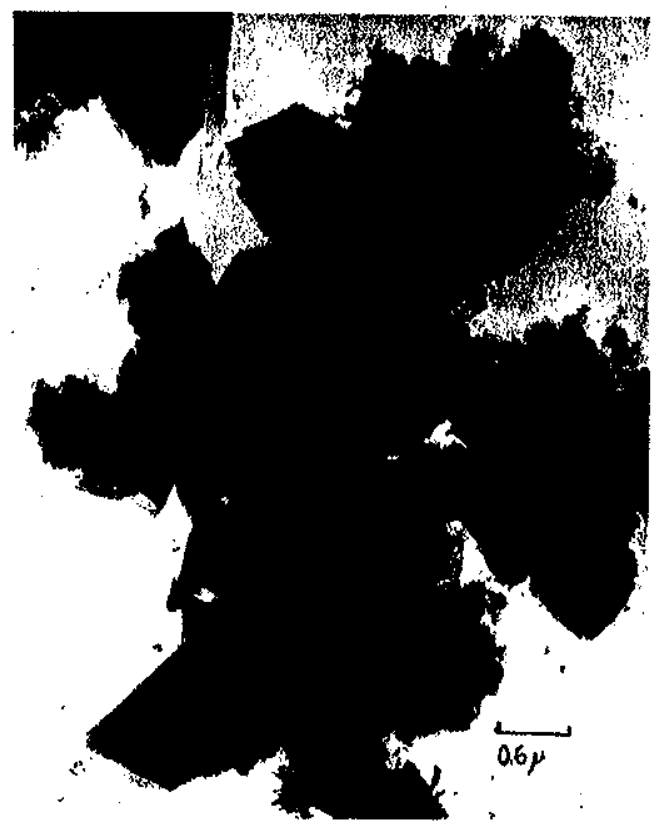

Figura 18: Micrografia eletrônica de transmissão da amostra M-2. 


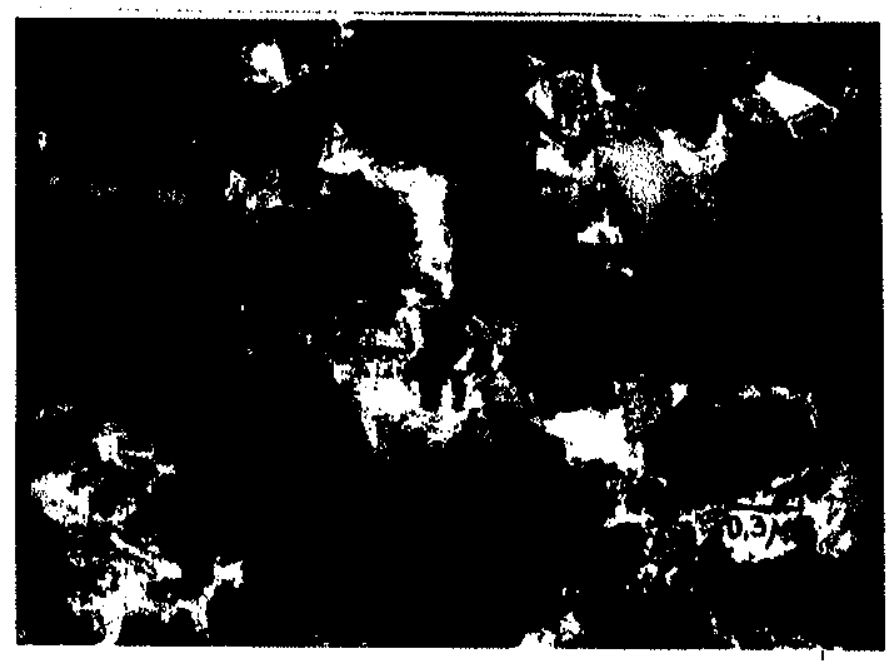

Figuras 19: Micrografia eletrônica de transmissão da amostra M-4.

As micrografias eletrônicas obtidas através de microscópio de varredura mostram nitidamente a imagem da amostra expandida (Figuras 20(a) e (b)). A expansão decorrente do aquecimento brusco, provoca o aumento de até 30 vezes o volume original da amostra.

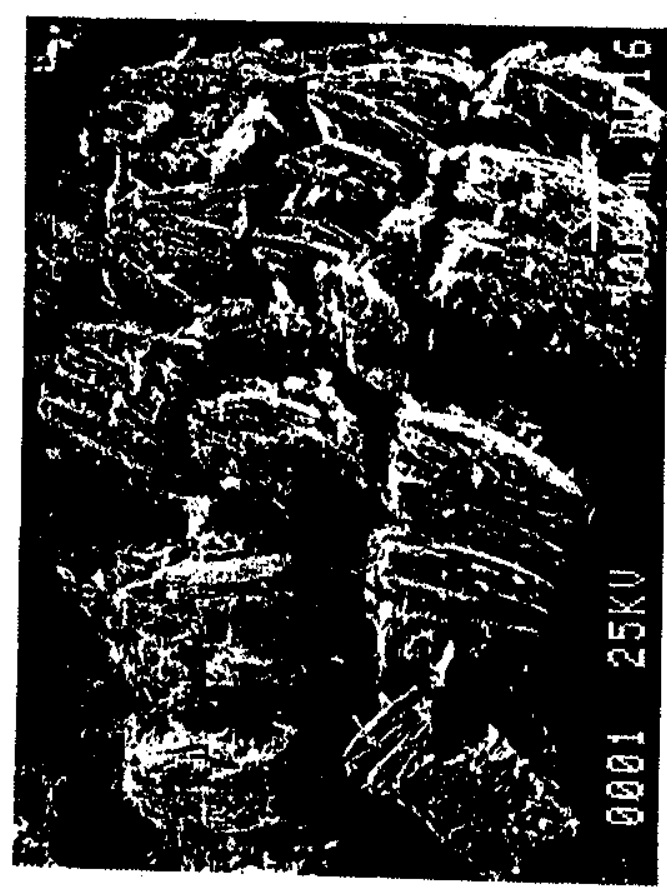

a

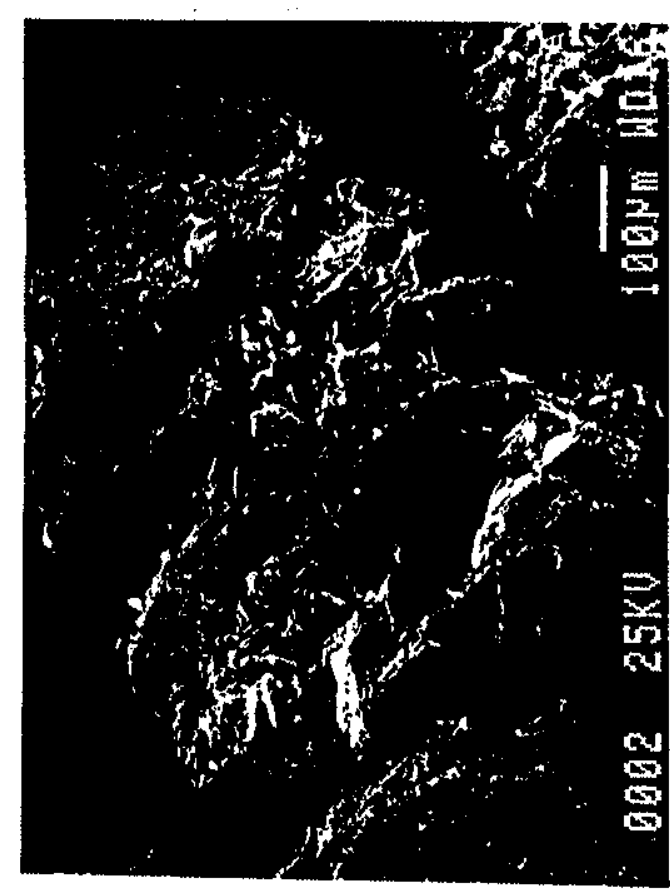

b

Figuras 20 (a) e (b): Micrografias eletrônicas de varredura da amostra M-4. 
Segundo Raman \& Jackson (1964) a composição da população interfoliar de uma vermiculita macroscópica pode interferir na micromorfologia do mineral. Um exemplo característico, dado pelos autores, é o enrugamento de algumas partes da superfície do mineral, devido à heterogeneidade dos cátions interfoliares.

A partir dessa informação pode-se considerar que as feições observadas nas micrografias eletrônicas são características das amostras estudadas. Infelizmente, não puderam ser realizados exames micromorfológicos de detalhe a fim de se verificar a existência de enrugamentos superficiais, como citam os autores acima.

\section{Superfície Especifica (SE)}

A determinação da superfície específica baseou-se em métodos relativos que promovem a adsorção de uma camada monomolecular de substâncias gasosas ao redor da superfície dos sólidos, sendo a quantidade de substâncias adsorvidas proporcional à área das partículas.

Foram determinadas as superficies externa e interna (Figura 21) das amostras estudadas.

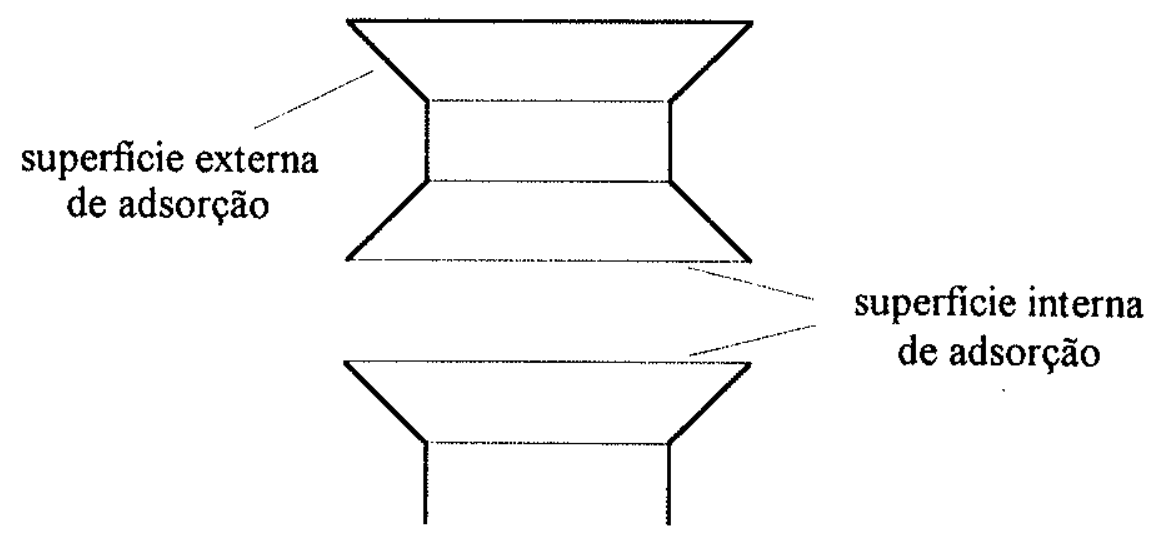

Figura 21: Representação esquemática da estrutura da vermiculita indicando as superfícies externa e interna. 
Para a determinação da superfície externa utlizou-se o método BET (Brunauer, Emmett, Teller).

A determinação da superfície interna baseou-se no método elaborado por Bower \& Gschwend (1952). Nesta determinação, as amostras foram secas $\left(100^{\circ} \mathrm{C}\right)$ e pesadas antes de de serem espalhadas sobre lâminas de vidro que, por sua vez, foram introduzidas num dessecador contendo cápsula com etileno-glicol (substância polar). O sistema foi aquecido à temperatura constante de $40^{\circ} \mathrm{C}$ durante, aproximadamente, 112 horas a fim de propiciar um ambiente com vapores de etileno-glicol. Decorrido este periodo, as amostras foram novamente pesadas, e a diferença obtida entre as massas correspondeu à quantidade de etileno-glicol adsorvido na superficie total (interna + externa) de cada amostra.

Para o cálculo considerou-se a área recoberta por uma camada monomolecular de etileno-glicol no espaçamento interfoliar do filossilicato. Sendo $3,22 \mathrm{~m}^{2}$ a área da superfície recoberta por $1 \mathrm{mg}$ de etileno-glicol (Grohmann 1972), multiplicou-se este valor por dois, uma vez que no caso da vermiculita existem duas superfícies para serem recobertas. Conhecendo-se o valor da superfície especifica externa bastou encontrar o valor correspondente em gramas de etilenoglicol que ocuparia esta região. Este valor foi, então, descontado daquele obtido com o método de saturação com a substância polar e utilizado no cálculo da superfície interna. A superfície específica total foi encontrada somando-se o valor das superfícies interna com a externa.

\section{Cálculo da superfície especifica interna}

$$
S E_{i}=\frac{\Delta m \times 1000}{m_{i}} \times 6,44
$$

onde,

$S E_{i}=$ Superfície Específica interna, em metros quadrados por grama $\left(\mathrm{m}^{2} / \mathrm{g}\right)$ $\Delta \mathrm{m}=$ massa de etileno-glicol adsorvida pelo mineral menos 0 correspondente à massa da mesma substância encontrada para a superfície externa, em gramas ( $\mathrm{g}$ )

$m_{i}=$ massa inicial de amostra, em gramas $(g)$ 


\section{RESULTADOS}

As determinações das superfícies especificas foram realizadas em duplicatas para cada amostra e a média dos valores obtidos encontram-se na tabela V. Nesta tabela, para comparação, são apresentados também os valores da SE das amostras de vermiculita de Beni-Uxera (África) (Lopez Gonzales \& Cano Ruiz 1957) e de Bihar (Índia) (Das \& Bandyopadhyay 1991).

\begin{tabular}{|c|c|c|c|c|c|c|}
\cline { 3 - 7 } \multicolumn{2}{c|}{} & \multicolumn{5}{c|}{ AMOSTRAS } \\
\hline \hline MÉTODO & SE & $M-1$ & $M-2$ & $M-4$ & VERM.AFRICA & VERM.INDLA \\
\hline BET & externa $\left(\mathrm{m}^{2} / g\right)$ & 13,70 & 10,70 & 17,50 & 84,00 & 14,50 \\
\hline BET-ET.GLI & interna $\left(\mathrm{m}^{2} / g\right)$ & 103,30 & 22,55 & 64,17 & $\ldots$ & $\ldots$ \\
\hline ET. GLICOL & total $\left(\mathrm{m}^{2} / g\right)$ & 117,00 & 33,25 & 81,67 & $\ldots$ & $\ldots$ \\
\hline
\end{tabular}

Tabela V: Superficie específica das vermiculitas crua fina (M-1) e grossa (M2), e da expandida grossa (M-4) obtidas pelo método de BET e etileno-glicol e das vermiculitas de Beni-Uxera (África) (Lopez Gonzales \& Cano Ruiz 1957) e de Bihar (Índia) (Das \& Bandyopadhyay 1991).

Considerando, inicialmente, a superfície externa obtida pelo método de BET, verifica-se que a amostra cominuída (M-1), como era de se esperar, aumentou em $28 \%$ de área em relação à amostra grossa (M-2). A forma expandida obteve aumento de $70 \%$ devido à esfoliação que, provavelmente, provocou o aumento do volume da estrutura do mineral.

A área interna correspondeu, para as amostras $M-1, M-2$ e $M-4$, respectivamente, $88 \%, 68 \%$ e $78 \%$ da área total. A partir desta observação podese afirmar que a maior área disponivel para troca ocorre principalmente na superfície interna do mineral. 
Verifica-se maior área específica total para a amostra cominuída, seguida pela expandida (M-4) e a de granulometria grossa (M-2).

Comparando os valores de BET obtidos neste trabalho com os de LopezGonzalez \& Cano Ruiz (1957) percebe-se grande diferença nos resultados devido aos métodos utilizados. Estes autores determinaram $\circ$ valor da superfície especifica de $84 \mathrm{~m}^{2} / \mathrm{g}$ à temperatura de $110^{\circ} \mathrm{C}$, e verificaram que a partir de $650^{\circ} \mathrm{C}$ havia diminuição para $11,00 \mathrm{~m}^{2} / \mathrm{g}$ e que permanecia constante. Acredita-se que este valor seja o mais representativo para a superfície externa, pois à temperatura de $110^{\circ} \mathrm{C}$ o mineral pode ter permitido a entrada parcial de $\mathrm{N}_{2}$ para o interior de sua estrutura, já que ela se fecha somente à temperatura superiores a $600^{\circ} \mathrm{C}$.

A maior área específica encontrada para a amostra de menor granulometria $(\mathrm{M}-1)$, já era esperada, uma vez que para uma mesma massa tem-se aumento com a diminuição das partículas.

\section{Análise Química}

A vermiculita crua micronizada foi analisada quimicamente pelos métodos quantitativos já mencionados.

Análises químicas semi-quantitativas também foram realizadas através de Espectrometria por Dispersão de Energia (EDS).

\section{RESULTADOS}

Os resultados analíticos dos elementos principais da amostra de vermiculita de Massapé-Paulistana encontram-se listados na tabela VI. 


\begin{tabular}{|c|c|}
\hline ÓXIDO & $\%$ \\
\hline $\mathrm{SiO}_{2}$ & 37,88 \\
\hline $\mathrm{Al}_{2} \mathbf{O}_{3}$ & 8,96 \\
\hline $\mathrm{CaO}$ & 2,98 \\
\hline $\mathrm{MgO}$ & 21,16 \\
\hline $\mathrm{Fe}_{2} \mathrm{O}_{3}$ & 6,02 \\
\hline $\mathbf{F e O}$ & 1,36 \\
\hline $\mathrm{Na}_{2} \mathrm{O}$ & 0,37 \\
\hline $\mathrm{K}_{\mathbf{2}} \mathrm{O}$ & 1,56 \\
\hline $\mathbf{P}_{2} \mathbf{O}_{5}$ & 0,04 \\
\hline $\mathrm{TiO}_{\mathbf{2}}$ & 0,70 \\
\hline $\mathrm{MnO}$ & 0,08 \\
\hline $\mathrm{Li}_{2} \mathrm{O}$ & 0,02 \\
\hline $\mathrm{BaO}$ & 0,14 \\
\hline $\mathrm{H}_{2} \mathrm{O}^{+}$ & 9,94 \\
\hline $\mathrm{H}_{2} \mathrm{O}^{-}$ & 7,84 \\
\hline
\end{tabular}

Tabela VI: Principais constituintes químicos da vermiculita de MassapéPaulistana (PI).

O material apresenta quantidade significativa de potássio e de ferro devido à interferência das camadas de composição micácea do mineral interestratificado, que se encontra disseminada nas amostras de vermiculita; o elevado teor de magnésio já era esperado, por se tratar de um filossilicato trioctaédrico.

A porcentagem de água total, constituída pela soma da água não essencial $\left(\mathrm{H}_{2} \mathrm{O}\right)^{-}$com as hidroxilas estruturais $\left(\mathrm{H}_{2} \mathrm{O}\right)^{+}$apresenta pequena diferença em relação ao valor teórico $(20 \%)$ de uma vermiculita magnesiana (Mathieson \& Walker 1954). Essa diferença pode ter sido gerada pela rápida rehidratação da vermiculita durante a determinação da $\mathrm{H}_{2} \mathrm{O}^{-}$, impossibilitando o cálculo preciso da perda de água adsorvida em sua estrutura. Entretanto, como pode ser observado na análise termogravimétrica, a perda total de água da estrutura da vermiculita crua (M-1) é de 19,24\%. Este valor, por sua vez, aproxima-se mais daquele encontrado pelos autores acima, e por esta razão será adotado para o cálculo da fórmula estrutural. 
O resultado obtido pela EDS encontra-se ilustrado na figura 22.

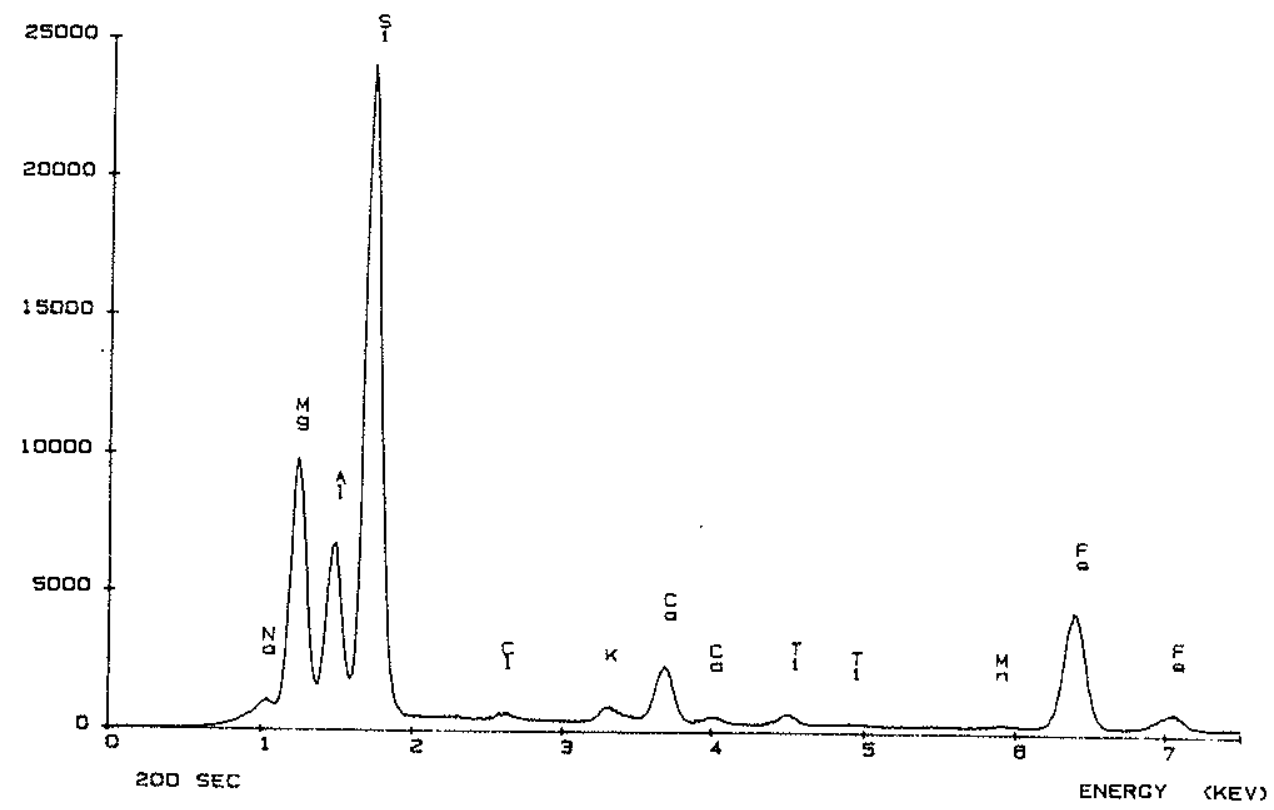

Figura 22: Diagrama obtido por EDS para a vermiculita de MassapéPaulistana.

\subsection{Fórmula Estrutural da vermiculita de Massapé-Paulistana}

A fórmula estrutural de um argilomineral pode variar em relação à sua fórmula ideal, devido a substituições isomórficas que cada espécie pode apresentar.

A fórmula estrutural-padrão de uma vermiculita pode ser escrita da seguinte forma (Calle \& Suquet 1988):

$\mathrm{Mg}_{\mathrm{x}}(\mathrm{Mg}, \mathrm{Fe}, \mathrm{Al})_{3}\left[(\mathrm{Al}, \mathrm{Si})_{4} \cdot \mathrm{O}_{10}\right](\mathrm{OH})_{2} \cdot 4 \mathrm{H}_{2} \mathrm{O}$, onde: $0,9<\mathrm{x}<0,6$; 
A partir dos dados quimicos da amostra de vermiculita estudada, calculou-se sua fórmula estrutural.

O cálculo utilizado para a conversão dos valores obtidos na análise química em fórmula estrutural baseou-se no método proposto por Jackson et al. (1967), para filossilicatos. Este método fornece o número de átomos por unidade estrutural e é calculado a partir dos constituintes químicos do mineral em forma de óxidos. Os resultados obtidos encontram-se na tabela VII.

\begin{tabular}{|c|c|c|c|c|c|c|}
\hline óxidos & $\%$ & P.M. & Eg óxido & \%Eq.peso & Eq/fórmula & $\mathbf{n}^{\mathbf{0}}$ atômico \\
\hline $\mathrm{SiO}_{2}$ & 37,88 & 60,078 & 15,019 & 2,522 & 12,174 & 3,043 \\
\hline $\mathrm{Al}_{2} \mathrm{O}_{3}$ & 8,96 & 101,960 & 16,993 & 0,527 & 2,544 & 0,848 \\
\hline $\mathrm{MgO}$ & 21,26 & 40,304 & 20,152 & 1,050 & 5,068 & 2,534 \\
\hline $\mathrm{CaO}$ & 2,98 & 56,079 & 28,039 & 0,106 & 0,512 & 0,234 \\
\hline $\mathrm{Na}_{2} \mathrm{O}$ & 0,37 & 61,978 & 30,989 & 0,012 & 0,058 & 0,058 \\
\hline $\mathrm{K}_{2} \mathrm{O}$ & 1,56 & 94,179 & 47,089 & 0,033 & 0,159 & 0,159 \\
\hline $\mathrm{Fe}_{2} \mathrm{O}_{3}$ & 6,02 & 159,677 & 26,613 & 0,226 & 1,091 & 0,364 \\
\hline $\mathrm{FeO}$ & 1,36 & 71,839 & 35,919 & 0,038 & 0,183 & 0,091 \\
\hline $\mathrm{P}_{2} \mathrm{O}_{5}$ & 0,04 & 109,944 & 10,994 & 0,004 & 0,019 & 0,004 \\
\hline $\mathrm{TiO}_{2}$ & 0,70 & 79,898 & 19,974 & 0,035 & 0,169 & 0,042 \\
\hline MnO & 0,08 & 70,937 & 35,468 & 0,002 & 0,010 & 0,005 \\
\hline $\mathrm{Li}_{2} \mathrm{O}$ & 0,02 & 29,879 & 14,939 & 0,001 & 0,005 & 0,005 \\
\hline $\mathrm{BaO}$ & 0,14 & 153,299 & 76,649 & 0,002 & 0,010 & 0,005 \\
\hline $\mathrm{H}_{2} \mathrm{O}^{+}$ & 9,94 & 18,015 & & & & \\
\hline $\mathrm{H}_{2} \mathrm{O}^{-}$ & 7,84 & 18,015 & & & & \\
\hline
\end{tabular}

(fator normalizador $=4,827$ )

Tabela VII: Cálculo do conteúdo atômico da meia-cela unitária da vermiculita de Massapé-Paulistana. 
Dada a dificuldade encontrada na determinação da água total, optou-se para a fixação do conteúdo atômico de $\mathrm{OH}^{-}$em 2,00, que equivale à $3,72 \%$ de $\mathrm{H}_{2} \mathrm{O}^{+}$. Este valor coincide com aquele determinado pela análise termogravimétrica da amostra M-1 (3,73\%), que também corresponde à liberação das hidroxilas estruturais, causando seu colapso e a irreversibilidade do processo de hidratação. Subtraindo-se o valor de $\mathrm{OH}^{-}$do conteúdo total de $\mathrm{H}_{2} \mathrm{O}$ perdida $(19,24 \%)$, durante a análise termogravimétrica da amostra $\mathrm{M}-1$, tem-se para a água estrutural o valor de $15,52 \%$.

Com esses dados definiu-se a fórmula estrutural da vermiculita de MassapéPaulistana:

$$
\begin{gathered}
\left(\mathrm{Ca}_{0,256} \mathrm{~K}_{0,159} \mathrm{Na}_{0,058}\right)\left(\mathrm{Mg}_{2,56} \mathrm{Fe}^{3+}{ }_{0,255} \mathrm{Fe}^{2+}{ }_{0,092} \mathrm{Ti}_{0,042} \mathrm{Mn}_{0,005} \mathrm{Li}_{0,005}\right) \\
{\left[\left(\mathrm{Si}_{3,043} \mathrm{Al}_{0,848} \mathrm{Fe}^{3+}{ }_{0,109}\right) \mathrm{O}_{10}\right] \cdot(\mathrm{OH})_{2} \cdot 4,16 \mathrm{H}_{2} \mathrm{O}}
\end{gathered}
$$

A distribuição da carga catiônica na estrutura está de acordo com a proposta por Calle \& Suquet (1988), que estudando o diagrama de Köster (1982 apud Calle $\&$ Suquet 1988) verificaram que as vermiculitas se caracterizam por apresentarem 15 cargas positivas na folha tetraédrica, 6 a 7 na octaédrica e entre 0 a 1 no espaço interfoliar.

$\mathrm{Na}$ amostra estudada a distribuição de cargas elétricas na estrutura é a seguinte:

- Folha tetraédrica $=+15,043$;

- Folha octaédrica $=+6,250$;

- Espaço interfoliar $=+0,729$.

Estas cargas tem por função neutralizar a carga negativa total $(-22)$, por meia-cela unitária.

A distribuição dos íns nas camadas estruturais da vermiculita leva, principalmente, em consideração o tamanho dos íons. A carga ou valência dos íons não constitui um fator determinante na substituição atômica, já que a neutralidade elétrica é sempre mantida na estrutura.

$\mathrm{Na}$ fórmula química, proposta para a vermiculita de Massapé-Paulistana, o $\mathrm{Al}^{3+}$ e $\circ \mathrm{Fe}^{3+}$ substituem parte do $\mathrm{Si}^{4+}$ na folha tetraédrica, pois ambos apresentam número de coordenação que pode variar entre 4 e $6 . \mathrm{Na}$ folha octaédrica $\circ \mathrm{Mg}^{2+}$ é substituido por grande variedade de cátions, como: $\mathrm{Fe}^{3+}$, $\mathrm{Fe}^{2+}, \mathrm{Ti}^{4+}, \mathrm{Li}^{+}$e $\mathrm{Mn}^{2+}$. 
Para manter a neutralidade elétrica e o equilibrio da estrutura os ions cálcio, potássio e sódio foram introduzidos no espaço interfoliar, pois todos apresentam raio iônico demasiadamente grande para ocuparem os vazios tetraédricos e/ou octaédricos.

A presença de $\mathrm{K}^{+}$na posição interfoliar não afeta, sobremaneira, a representação da fórmula estrutural da vermiculita. Além disso, cabe ressaltar que a mesma dificilmente ocorre na natureza sem deixar resquíceos da composição da mica que a originou.

\section{Capacidade de Troca Catiônica (CTC)}

O método convencional para a determinação da capacidade de troca catiônica baseia-se na saturação da amostra com solução contendo um cátion adequado para efetuar a troca. No final do tratamento, a solução é filtrada, e o sólido lavado várias vezes com água destilada. O cátion fixado no sólido é posteriormente deslocado por outro, de natureza conhecida, e a seguir dosado quimicamente.

$\mathrm{O}$ método mais comum utiliza $\circ \mathrm{NH}_{4}{ }^{+}$, na forma, de acetato como cátion trocador (Hesse 1971). Este método apresenta incovenientes como:

- baixos resultados em meio neutro, devido sua fixação na estrutura da vermiculita;

- perda de $\mathrm{NH}_{4}{ }^{+}$na forma de amônia e

- demora na determinação que inclui o processo de destilação ( Nicot \& Facundo 1970; Rosemburg 1972).

Neste trabalho, a determinação da CTC foi efetuada por dois métodos:

O primeiro, proposto por Nicot \& Facundo (1970), apresenta vantagens sobre o clássico devido à facilidade de execução e à precisão de seus resultados. Este método é apresentado de modo esquemático na figura 23. 


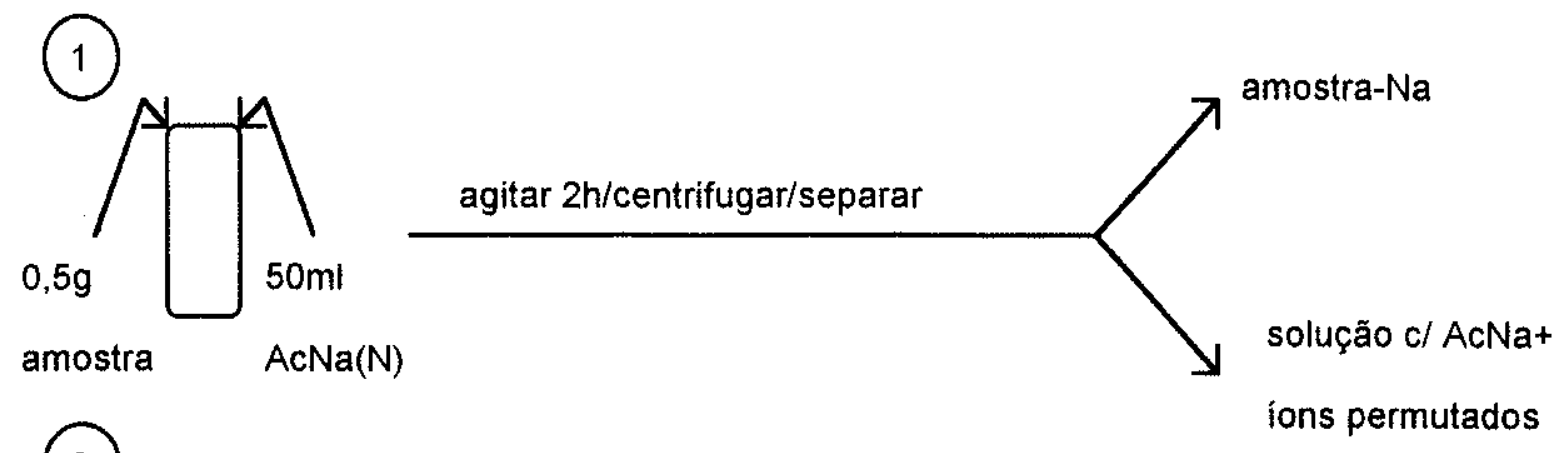

(2)
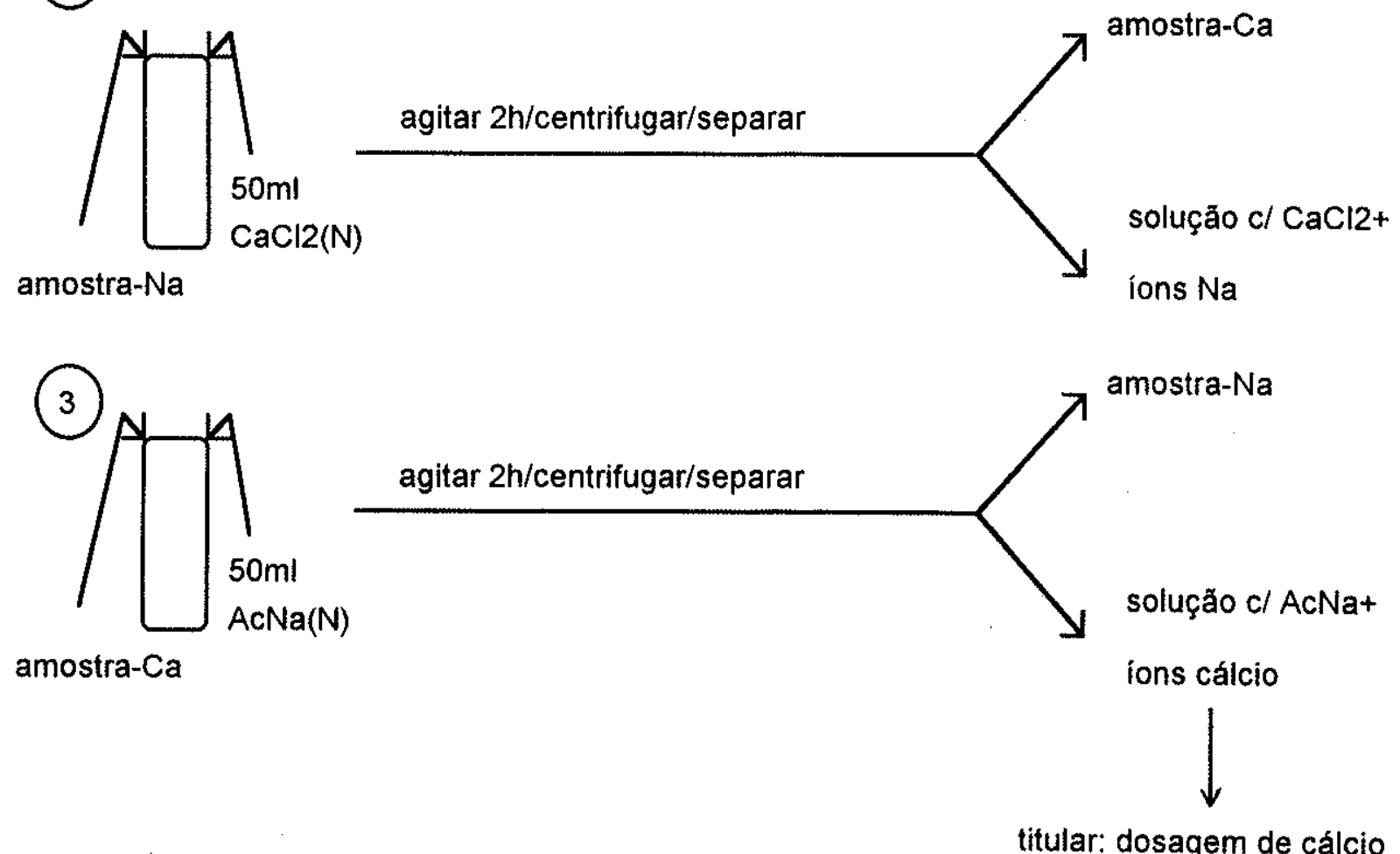

Figura 23: Esquema do método de obtenção de CTC segundo Nicot \& Facundo (1970). 
O segundo método, desenvolvido neste trabalho, teve como objetivo simplificar o anterior com diminuição das etapas de operações que se acham, a seguir, descritas com detalhes. O método encontra-se esquematizado na figura 24 .

\section{MATERIAIS UTILIZADOS}

- Amostra de vermiculita crua fina (M-1), crua grossa ( $M-2)$, expandida fina (M3) e expandida grossa (M-4);

- Soluções:

a) Acetato de Sódio (N), em pH =7,2

b) Ácido etilenodiaminotetracético $(0,04 \mathrm{M})(14,8896 \mathrm{~g}$ de EDTA dissolvido em $1000 \mathrm{~mL}$ de água destilada)

c) Cloreto de cálcio $(0,3 \mathrm{~N})$, com $\mathrm{pH}=7,2$. Preparo:

- pesar $16,00 \mathrm{~g}$ de carbonato de cálcio em béquer de 1000 $\mathrm{mL}$ e acrescentar $300 \mathrm{~mL}$ de água destilada;

- adicionar lentamente (agitando sempre) ácido clorídrico 1:1 até total dissolução do sal;

- acertar o pH da solução para 7,2 com hidróxido de sódio $(0,1 \mathrm{~N})$

- avolumar a solução para $1000 \mathrm{~mL}$.

\section{PROCEDIMENTO}

- Pesar $0,5000 \mathrm{~g}$ de amostra em tubo de centrífuga;

- Acrescentar $50 \mathrm{~mL}$ de acetato de sódio $(\mathrm{N} ; \mathrm{pH}=7,2)$ e manter a mistura por 2 horas, agitando-o frequentemente;

- Centrifugar e remover o sobrenadante;

- Adicionar ao resíduo $50 \mathrm{~mL}$ de solução de cloreto de cálcio $(0,3 \mathrm{~N} ; \mathrm{pH}=7,2)$ e deixar em contato por 2 horas, com agitação;

- Centrifugar e transferir o sobrenadante para balão volumétrico de $250 \mathrm{~mL}$;

- Lavar o resíduo ( 2 vezes com $10 \mathrm{ml}$ de água destilada e em seguida com álcool etílico $80 \%$ até ausência de cloreto);

- Recolher toda solução de lavagem em balão de $250 \mathrm{~mL}$ e avolumá-lo;

- Determinar o teor de cálcio na amostra. 


\section{DOSAGEM DO CÁLCIO}

- Pipetar $20 \mathrm{~mL}$ da solução;

- Adicionar $50 \mathrm{~mL}$ de água destilada e $10 \mathrm{~mL}$ de solução de trietanolamina $50 \%$;

- Ajustar o pH a 12,5-13,0 com solução de hidróxido de potássio 20\%;

- Adicionar 18 gotas de solução do indicador azul de hidroxinaftol e imediatamente titular com $\operatorname{EDTA}(0,04 \mathrm{M})$ até viragem de cor vermelho violeta para azul intenso;

- Anotar o volume de EDTA gasto.

Obs: Fazer determinação em duplicata e inclusive da solução de $\mathrm{CaCl}_{2}$ $(0,3 N)$.

\section{CÁLCULO}

$C T C=199,47 \times \Delta V_{E D T A}$

onde,

CTC = Capacidade de Troca Catiônica em miliequivalentes de cálcio por 100 $\mathrm{g}$ de amostra (meq $\mathrm{Ca} / 100 \mathrm{~g}$ )

$\Delta \mathrm{V}_{\text {EDTA }}=$ Variação entre 0 volume $(\mathrm{ml})$ de EDTA gasto na titulação da solução de $\mathrm{CaCl} 2(0,3 \mathrm{~N})$ e da solução lixiviante (do balão $250 \mathrm{ml}$ ).

(1)

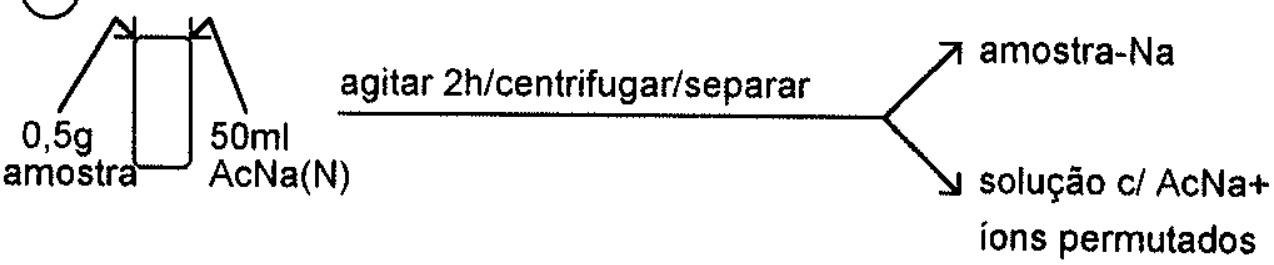

(2)

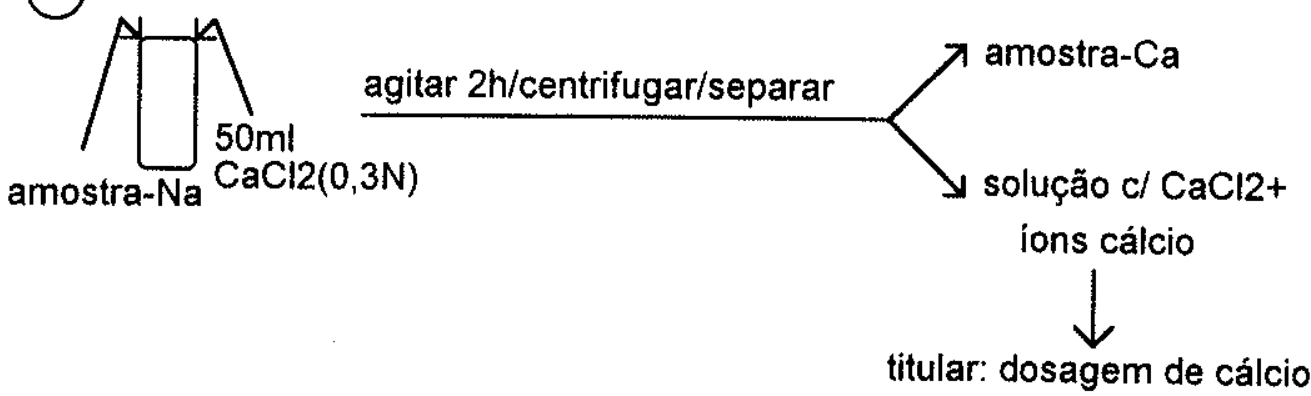

Figura 24: Esquema do método simplificado de obtenção de CTC. 
RESULTADOS

Os valores obtidos através dos dois métodos encontram-se listados na tabela VIII.

\begin{tabular}{|l|c|c|}
\hline \multirow{2}{*}{ VERMICULITA } & \multicolumn{2}{|c|}{ CTC (meq Ca/100g de amostra) } \\
\cline { 2 - 3 } & (1) & (2) \\
\hline \hline M-1(crua fina) & 155,19 & 139,07 \\
\hline M-2(crua grossa) & $\ldots$ & 80,78 \\
\hline M-3(exp.fina) & $-\ldots$ & 43,87 \\
\hline M-4(exp.grossa) & 47,11 & 46,38 \\
\hline
\end{tabular}

Tabela VIII: Capacidade de troca de cátions (CTC) da vermiculita de Massapé-Paulistana, pelo método (1) de Nicot \& Facundo (1970) e deste trabalho (2).

O maior valor de CTC verifica-se na vermiculita crua de fração mais fina (M1) e, em seguida, na de fração grossa (M-2). As formas expandidas fina (M-3) e grossa (M-4) apresentam valores inferiores que os das amostras cruas. valores.

Como se pode verificar a metodologia utilizada não interfere na grandeza dos

Foster (1963) elaborou - a partir da análise de fórmulas estruturais de diversas amostras de vermiculita de procedências variadas - uma relação empírica, através da qual obteve o valor da CTC sem utilizar métodos laboratoriais. Esta relação consiste apenas em multiplicar pelo fator 200 o valor da carga positiva interfoliar calculado para a amostra. No caso da vermiculita de MassapéPaulistana, com carga interfoliar de 0,729 , o valor da CTC segundo aquela relação é de 145 meq $\mathrm{Ca} / 100 \mathrm{~g}$ de amostra. 


\section{Relação composicional entre vermiculita e mica de origem}

Com o objetivo de estabelecer a origem mais provável da vermiculita estudada, construiu-se um diagrama triangular (Figura 25) projetando teores de magnésio, ferro (II) (manganês) e os íons trivalentes $\left(\mathrm{Al}^{3+}, \mathrm{Fe}^{3+}\right)$ da composição do mineral. Foster (1963) definiu neste diagrama, a partir da projeção de 135 análises químicas de micas trioctaédricas, os campos correspondentes a flogopita, biotita magnesiana, biotita ferrifera e siderofilitas / lepidomelanas.

A projeção dos dados analíticos obtidos para a amostra estudada revela composição octaédrica similar à da flogopita.

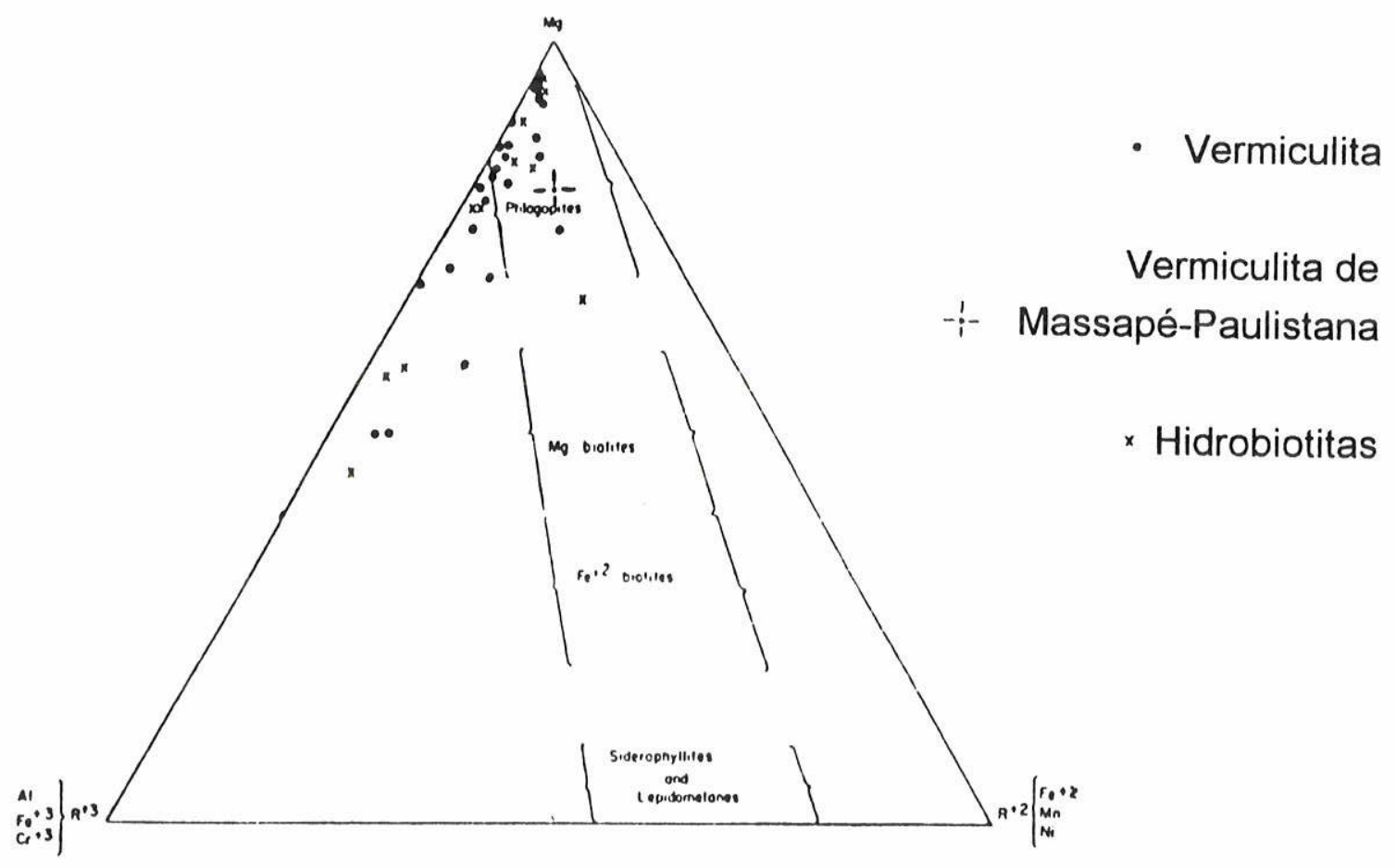

Figura 25: Relação entre $\mathrm{Mg}^{2+}, \mathrm{Fe}^{2+}\left(\mathrm{Mn}^{2+}\right)$ e $\mathrm{R}^{3+}\left(\mathrm{Al}^{3+}, \mathrm{Fe}^{3+}\right)$ das micas trioctaédricas (Foster 1963). 


\section{TRABALHOS EXPERIMENTAIS}

Nesta fase, procurou-se estudar a eficiência de troca catiônica da vermiculita de Massapé-Paulistana, e também determinar as melhores condições em que ela ocorre.

Os experimentos desenvolveram-se em etapas (experiências $A, B$ e $C$ ), que se encontram detalhadas a seguir.

\section{-EXPERIÊNCIA A: escolha de granulometria favorável à troca iônica}

Esta experiência teve como objetivo principal estabelecer granulometria mais favorável à troca entre os cátions interfoliares da amostra com os da solução, e consequentemente promover a vermiculitização total das camadas de mica do interestratificado.

\section{MATERIAIS}

- Vermiculita crua fina (M-1) e crua grossa(M-2);

- Solução de $\mathrm{MgCl}_{2} \cdot 6 \mathrm{H}_{2} \mathrm{O}(\mathrm{N})$.

\section{CONDICOOES EXPERIMENTAIS}

$$
\begin{aligned}
& M_{i} \text { amostra }=1,0000 \mathrm{~g} \\
& V_{i \text { solução }}=100 \mathrm{~mL} \\
& T=55{ }^{\circ} \mathrm{C} \\
& t=24 \mathrm{~h}
\end{aligned}
$$




\section{PROCEDIMENTO}

- Pesar $1,0000 \mathrm{~g}$ de cada amostra e transferir para béqueres de $300 \mathrm{~mL}$;

- Adicionar $100 \mathrm{~mL}$ de solução de $\mathrm{MgCl}_{2} \cdot 6 \mathrm{H}_{2} \mathrm{O}(\mathrm{N})$ e agitar por alguns minutos;

- Aquecer por 24 horas em banho termostatizado à temperatura de $55^{\circ} \mathrm{C}$;

- Filtrar as misturas em papel de filtração lento e lavar até ausência de cloreto;

- Recolher os filtrados em balões volumétricos de $200 \mathrm{~mL}$;

- Recolocar as amostras sólidas retidas nos filtros novamente nos respectivos béqueres e adicionar $100 \mathrm{~mL}$ da solução de cloreto;

- Manter as misturas aquecidas $\left(55^{\circ} \mathrm{C}\right)$ sob agitação por mais 24 horas;

- Filtrar novamente os sistemas e recolher os filtrados nos mesmos balões;

- Recolocar as amostras nos béqueres e repetir as três últimas etapas;

- No final, analisar quimicamente os filtrados recolhidos nos balões.

\section{RESULTADOS}

Os teores de cálcio e potássio interfoliares extraídos das amostras originais encontram-se listados na tabela IX e, na figura 26 , sua projeção em função do tempo de contato.

\begin{tabular}{|c|c|c|c|c|}
\cline { 2 - 5 } \multicolumn{1}{c|}{} & \multicolumn{2}{c|}{ M-1 (verm.crua fina) } & \multicolumn{2}{c|}{ M-2 (verm.crua grossa) } \\
\hline CTC & meq Ca/100g & meq K/100g & meq Ca/100g & meq K/100g \\
\hline SUBTOTAL & 111,53 & 22,50 & 33,88 & 15,34 \\
\hline TOTAL & \multicolumn{2}{|c|}{134,03 meq/100g } & \multicolumn{2}{c|}{49,22 meq $/ 100 \mathrm{~g}$} \\
\hline
\end{tabular}

Tabela IX: Teores de cálcio e potássio extraídos da estrutura das amostras $\mathrm{M}-1$ e M-2 lixiviadas com $\mathrm{MgCl}_{2} \cdot 6 \mathrm{H}_{2} \mathrm{O}(\mathrm{N})$ na experiência $\mathrm{A}$. 


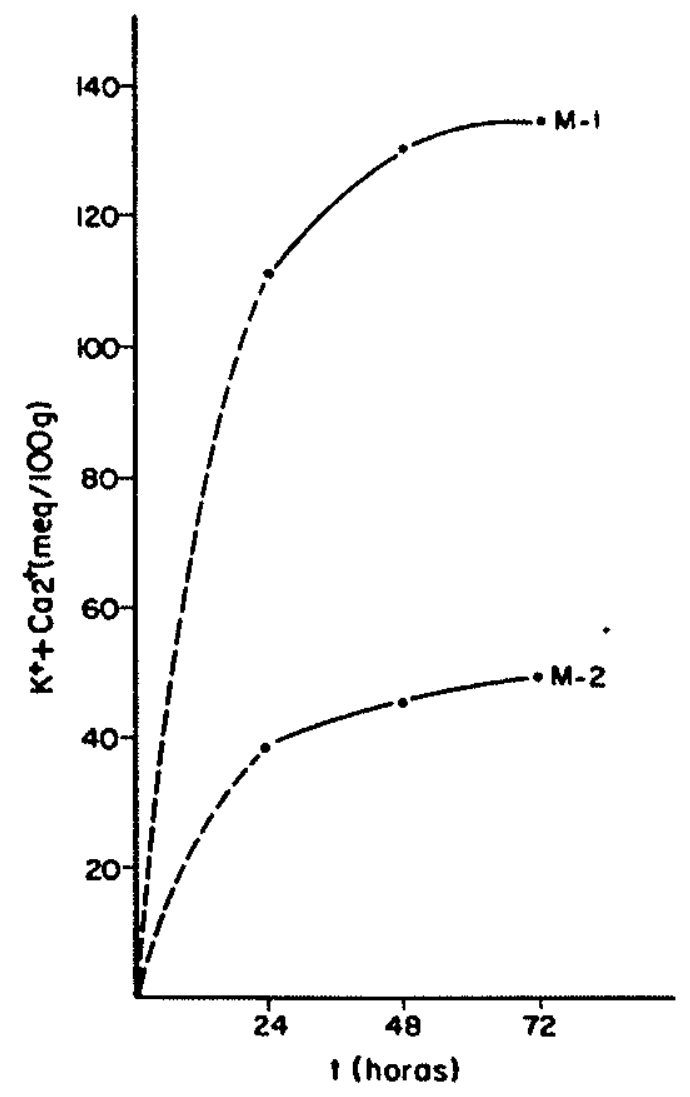

Figura 26: Projeção dos teores dos ions cálcio e potássio liberados para a solução em função do tempo de tratamento da experiência $A$.

Examinando as curvas obtidas na figura 26 verifica-se que no primeiro tratamento (24 horas) grande parte dos íons cálcio e potássio é eliminada das amostras e, observa-se, também, que com o aumento do tempo de tratamento, os teores destes elementos diminuem na solução lixiviante. Este tipo de comportamento é de se esperar pois, inicialmente, as taxas de sorção de uma fase líquida para sólida são altas e logo diminuem, gradativamente, até estabelecerem o equilibrio.

No experimento em questão, as amostras de vermiculita estudadas foram saturadas com solução de cloreto de magnésio para promover a troca dos cátions interfoliares (cálcio e potássio) por magnésio. Segundo a análise química deste mineral, há originalmente cerca de $110,79 \mathrm{meq} / 100 \mathrm{~g}$ de cálcio e $32,89 \mathrm{meq} / 100 \mathrm{~g}$ de potássio na região interfoliar. $O$ total de $\mathrm{Ca}^{2+}$ extraído da amostra $\mathrm{M}-1$ é de $111,53 \mathrm{meq} / 100 \mathrm{~g}$ e de $\mathrm{K}^{+}, 22,50 \mathrm{meq} / 100 \mathrm{~g}$. A princípio, parece que $\circ \mathrm{Mg}^{2+}$ consegue substituir todo $\circ \mathrm{Ca}^{2+}$ interfoliar, ao passo que ainda permanecem algum $\mathrm{K}^{+}$na estrutura do mineral. 
Tal fato pode ocorrer devido à maior facilidade que $\circ \mathrm{Mg}^{2+}$ possui em substituir $\circ \mathrm{Ca}^{2+}$ ao invés do $\mathrm{K}^{+}$, pois nem todos os cátions conseguem ser trocados com a mesma intensidade, por não estarem ligados ao retículo cristalino do mineral pela mesma força. A facilidade de troca pode ainda variar em função das dimensões dos ions e de seus graus de hidratação.

Os tratamentos realizados com a vermiculita crua grossa (M-2) não foram tão eficientes como quando realizados com a amostra de fração mais fina. Isto se deve, principalmente, à área especifica e ao número de arestas rompidas, que aumentam quando se diminui a granulometria da amostra, causando aumento na capacidade de adsorção e troca de íons do mineral com os disponíveis no meio.

A partir da análise dos resultados destes ensaios, optou-se por utilizar a vermiculita crua micronizada ( $M-1)$ nos experimentos seguintes.

\section{-EXPERIÊNCIA B (3 fases): troca com soluções salinas}

\section{-1a Fase:}

Este experimento teve como objetivo promover a troca de cátions interfoliares da vermiculita pelos das soluções salinas para estudar a facilidade de troca catiônica com diferentes cátions.

\section{MATERIAIS}

- Vermiculita crua fina (M-1);

- Soluções:
a) $\mathrm{MgCl}_{2} \cdot 6 \mathrm{H}_{2} \mathrm{O}(\mathrm{N})$;
b) $\mathrm{BaCl}_{2} \cdot 2 \mathrm{H}_{2} \mathrm{O}(\mathrm{N})$;
c) $\mathrm{KCl}(\mathrm{N})$;
d) $\mathrm{NaCl}(\mathrm{N})$;
e) $\operatorname{EDTA}(0,04 \mathrm{M})$. 


\section{CONDICÕES EXPERIMENTAIS}

$M_{\mathrm{i}}$ vermiculita $=2,0000 \mathrm{~g}$

$V_{i}$ solução $=200 \mathrm{~mL}$

$\mathrm{T}=40^{\circ} \mathrm{C}$

$t=5,10,30$ e 40 dias

\section{PROCEDIMENTO}

- Introduzir as amostras $(2,0000 \mathrm{~g})$ em béqueres de $400 \mathrm{~mL}$ e acrescentar 200 $\mathrm{mL}$ das respectivas soluções;

- Aquecer $\left(40^{\circ} \mathrm{C}\right)$ os sistemas agitando-os frequentemente;

- Após o período determinado, filtrar as misturas em papel de filtração lenta e lavar até ausência de cloreto;

- Analisar quimicamente os filtrados recolhidos em balóes volumétricos de 250 $\mathrm{mL}$;

- Difração de raios $X$ dos sólidos retidos nos filtros.

Obs: serão, a partir desta etapa, utilizados os símbolos $\mathrm{V}$ de vermiculita crua micronizada (M-1), seguido do símbolo dos íns e números que representarão o tempo de contato com a solução (Tabela X).

\begin{tabular}{|c|c|c|c|c|}
\hline & \multicolumn{4}{|c|}{ PERÍODO } \\
\hline SISTEMA & 5 dias & 10 dias & 30 dias & 40 dias \\
\hline $\mathrm{VERM}+\mathrm{NaCl}(\mathbf{N})$ & $\mathrm{VNa}-05$ & $\mathrm{VNa}-10$ & $\mathrm{VNa}-30$ & $\mathrm{VNa}-40$ \\
\hline VERM+KCl (N) & VK- 05 & VK- 10 & VK- 30 & VK - 40 \\
\hline $\mathrm{VERM}+\mathrm{BaCl}_{2} .2 \mathrm{H}_{2} \mathrm{O}(\mathrm{N})$ & $\mathrm{VBa}-05$ & $\mathrm{VBa}-10$ & $\mathrm{VBa}-30$ & $\mathrm{VBa}-40$ \\
\hline $\mathrm{VERM}+\mathrm{MgCl}_{2} .6 \mathrm{H}_{2} \mathrm{O}(\mathrm{N})$ & $\mathrm{VMg}-05$ & $\mathrm{VMg}-10$ & VMg-30 & VMg-40 \\
\hline VERM+EDTA $(0,04 M)$ & VED-05 & VED-10 & VED-30 & VED-40 \\
\hline
\end{tabular}

Tabela X: Amostras tratadas com soluções salinas em periodos variados. 


\section{RESULTADOS}

Os teores de cálcio, magnésio e potássio lixiviados das amostras encontramse na tabela XI.

\begin{tabular}{|c|c|c|c|}
\cline { 2 - 4 } \multicolumn{1}{c|}{} & \multicolumn{3}{c|}{ CÁTIONS LIXIVIADOS (meq/100g) } \\
\hline AMOSTRAS & CÁLCIO & POTÁSSIO & MAGNÉSIO \\
\hline VNa-05 & 72,36 & 12,66 & 59,23 \\
\hline VNa-10 & 95,81 & 12,92 & 12,34 \\
\hline VNa-30 & 98,80 & 13,05 & 13,16 \\
\hline VNa-40 & 102,79 & 13,05 & 3,29 \\
\hline VK-05 & 57,38 & $\ldots$ & 77,33 \\
\hline VK-10 & 92,81 & $\ldots$ & 8,23 \\
\hline VK-30 & 121,76 & $\ldots$ & 6,58 \\
\hline VK-40 & 122,75 & $\ldots$ & 1,65 \\
\hline VBa-05 & 32,43 & 38,12 & 97,89 \\
\hline VBa-10 & 52,89 & 40,16 & 78,15 \\
\hline VBa-30 & 83,83 & 41,70 & 41,13 \\
\hline VBa-40 & 72,85 & 43,23 & 46,07 \\
\hline VMg-05 & 97,30 & 11,13 & $\ldots$ \\
\hline VMg-10 & 100,80 & 11,38 & $\ldots$ \\
\hline VMg-30 & 108,78 & 13,05 & $-\ldots$ \\
\hline VMg-40 & 107,78 & 12,79 & $\ldots-$ \\
\hline VED-05 & 117,26 & 0,00 & 45,25 \\
\hline VED-10 & 118,26 & 0,00 & 51,00 \\
\hline VED-30 & 126,75 & 0,00 & 40,31 \\
\hline VED-40 & 117,76 & 0,00 & 46,07 \\
\hline
\end{tabular}

Tabela XI: Teores de $\mathrm{Ca}^{2+}, \mathrm{Mg}^{2+}$ e $\mathrm{K}^{+}$removidos da estrutura da vermiculita por soluções salinas. 
A partir dos valores obtidos para os principais íons interfoliares $\left(\mathrm{Ca}^{2+} \mathrm{e} \mathrm{K}^{+}\right)$ liberados para a solução da vermiculita estudada, pode-se determinar quantitativamente os cátions que teriam, por sua vez, substituído os primeiros. Para os cálculos utilizou-se a seguimte fórmula:

$$
\frac{A \%}{E A}=\frac{B+C}{1000} \Rightarrow A \%=\frac{E A \times(B+C)}{1000}
$$

onde,
$A=$ conteúdo do cátion presente na solução salina (\%);
$\mathrm{B}=$ valor em meq/100g de $\mathrm{Ca}^{2+}$ liberado da estrutura da vermiculita estudada;
$\mathrm{C}=$ valor em meq/100g de $\mathrm{K}^{+}$liberado da estrutura da vermiculita estudada;
$\mathrm{EA}=$ equivalente-grama do cátion $\mathrm{A}$.

A elaboração desta fórmula se baseou na hipótese de que à quantidade de cátion liberado da estrutura do mineral existe um valor equivalente de ions da solução que passam a ocupar as posições então disponíveis. A tabela XII mostra os resultados deste cálculo.

\begin{tabular}{|c|c|c|c|c|c|}
\hline amostra & $\mathrm{Na}^{+}(\%)$ & amostra & $\mathrm{K}^{+}(\%)$ & amostra & $\mathrm{Ba}^{2+}(\%)$ \\
\hline VNa-05 & 1,95 & VK-05 & 2,24 & VBa-05 & 4,85 \\
\hline VNa-10 & 2,50 & VK-10 & 3,63 & VBa-10 & 6,39 \\
\hline VNa-30 & 2,57 & VK30 & 4,76 & VBa-30 & 8,62 \\
\hline $\mathrm{VNa}-40$ & 2,66 & VK40 & 4,80 & $\mathrm{VBa}-40$ & 7,97 \\
\hline & amostra & $\mathrm{Mg}^{2+}(\%)$ & amostra & $\mathrm{H}_{3} \mathrm{O}^{-}(\%)$ & \\
\hline & VMg-05 & 1,31 & VED-05 & 2,23 & \\
\hline & VMg-10 & 1,36 & VED-10 & 2,24 & \\
\hline & VMg-30 & 1,48 & VED-30 & 2,41 & \\
\hline & VMg-40 & 1,46 & VED-40 & 2,24 & \\
\hline
\end{tabular}

Tabela XII: Teores dos cátions das soluções salinas que substituiram o cálcio e o potássio interfoliares das amostras de vermiculita estudadas. 
O exame dos dados de análises químicas das soluções utilizadas, aliado aos resultados mineralógicos das amostras por difração de raios $X$, levaram às seguintes observações:

- No tratamento com $\mathrm{NaCl}(\mathrm{N})$ a remoção do $\mathrm{K}^{+}$interfoliar da vermiculita original permaneceu praticamente constante em todos as etapas com $39 \%$ deslocado para a solução. $O$ cálcio, por sua vez, teve o máximo de sua remoção $(96,68 \%)$ no tratamento que durou 40 dias. Os difratogramas destas amostras (Figura 27) mostram deslocamento dos principais picos de reflexões basais (001) indicando mudanças na espessura da estrutura.

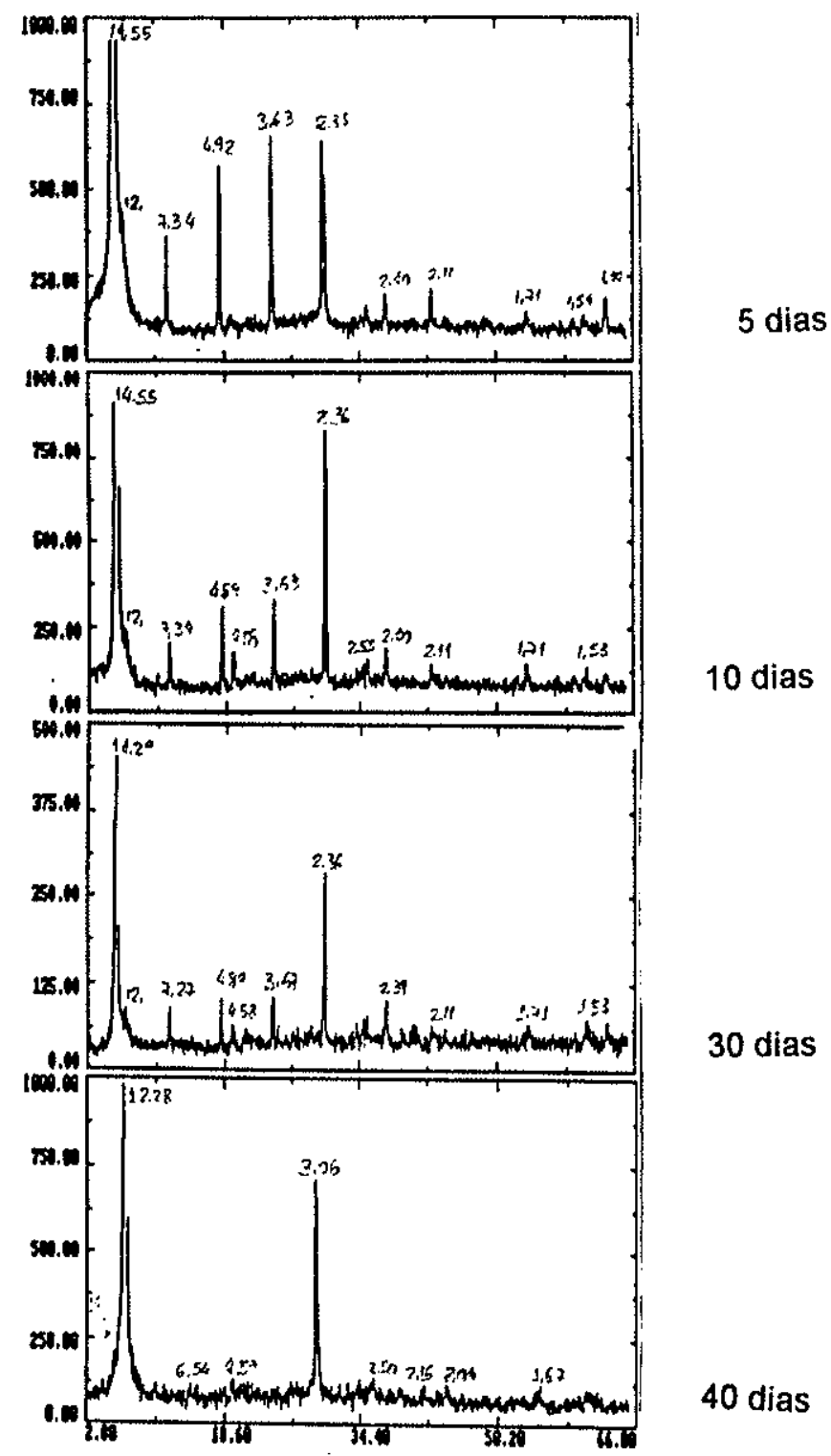

Figura 27: Difratogramas de raios $X$ das amostras de vermiculita $(M-1)$ tratadas com $\mathrm{NaCl}(\mathrm{N})$. 
O espaçamento basal d(002) da amostra que era de 14,5 A passou, depois do tratamento de 40 dias, para 12,3A. Essa contração da estrutura do mineral se deve principalmente à substituição dos cátions interfoliares originais $\left(\mathrm{K}^{+} \in \mathrm{Ca}^{2+}\right)$ pelo $\mathrm{Na}^{+}$da solução. $\mathrm{O} \mathrm{Na}{ }^{+}$, de raio iônico igual a $0,9 \AA$, possui grau de hidratação relativamente baixo, provocando diminuição na espessura do espaçamento basal do mineral. Segundo Barshad (1950), vermiculitas saturadas com sódio apresentam espaçamento basal equivalente à espessura de uma camada de água.

- O tratamento utilizando solução de $\mathrm{BaCl}_{2} \cdot 2 \mathrm{H}_{2} \mathrm{O}(\mathrm{N})$ foi eficiente na substituição do $\mathrm{K}^{+}$interfoliar, em todos os periodos. O mesmo não ocorreu com o $\mathrm{Ca}^{2+}$ interfoliar, que atingiu o máximo de sua remoção no período de 40 dias (remoção de $68,52 \%$ ). Os difratogramas de raios $X$ (Figura 28 ) mostram que a superfície basal (002), correspondente ao pico de maior intensidade sofre contração, atingindo espessuras, em média, de 12,3 A. Da mesma forma que ocorre com as amostras tratadas com $\mathrm{NaCl}(\mathrm{N})$, o cátion bário da solução, cujo raio iônico corresponde a 1,3 $\AA$ possui grau de hidratação relativamente baixo, motivo pelo qual provoca a diminuição do espaçamento basal original.

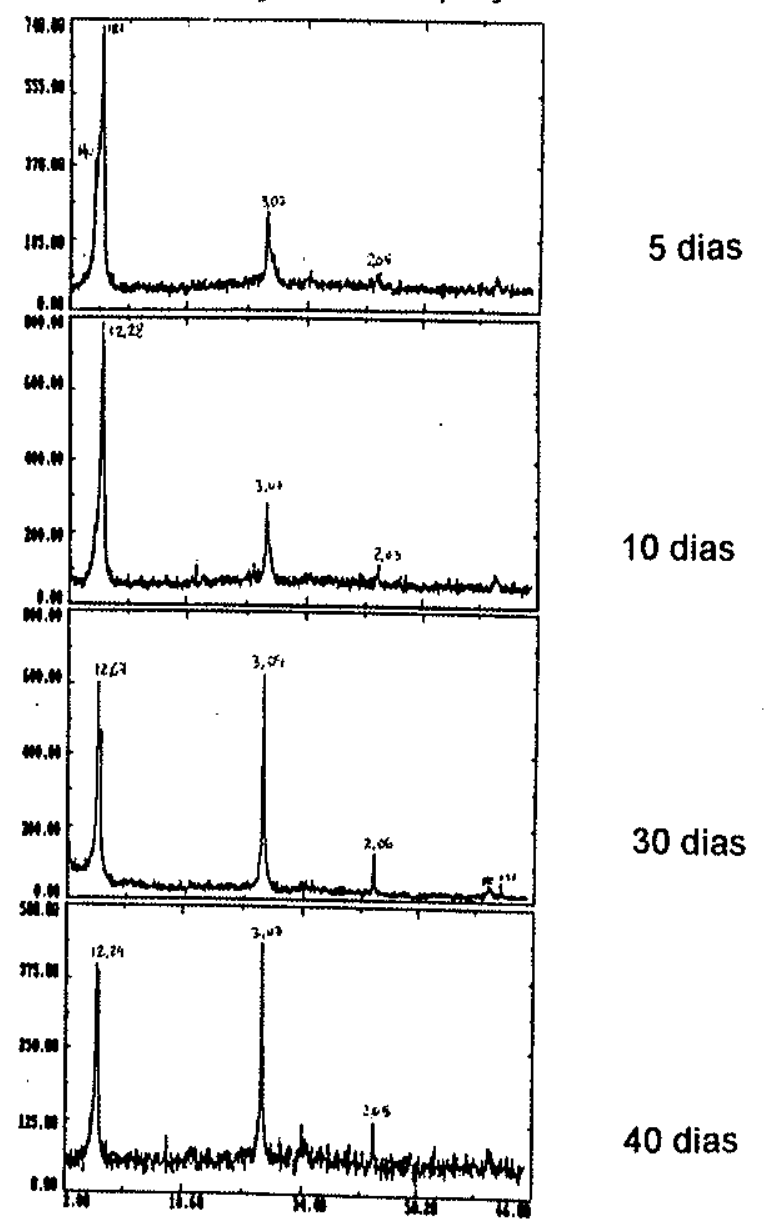

Figura 28: Difratogramas de raios $\mathrm{X}$ das amostras de vermiculita (M-1) tratadas com $\mathrm{BaCl}_{2} .2 \mathrm{H}_{2} \mathrm{O}(\mathrm{N})$. 
- Realizou-se o tratamento com solução de $\mathrm{KCl}(\mathrm{N})$ objetivando analisar a eficiência do cátion potássio em substituir o cálcio da região interfoliar da vermiculita. A total substituição do cálcio interfoliar ocorreu entre os períodos de 10 a 40 dias. Analisando os respectivos difratogramas (Figura 29) verifica-se que há, realmente, uma contração da estrutura na posição basal, fornecendo espaçamento de $10,1 \AA$ ao mineral. Essa contração na estrutura do mineral se deve ao raio iônico elevado do $\mathrm{K}^{+}$(raio iônico $=1,4 \AA$ ) que se encaixa perfeitamente nas cavidades ditrigonais das folhas tetraédricas adjacentes, opostas uma à outra, e cujo raio iônico é de $1,3 \AA$ (Calle \& Suquet 1988). O grau de hidratação do $\mathrm{K}^{+}$é muito baixo tornando-o praticamente quase anidro e por isso a estrutura da amostra saturada com este cátion não se expande, assemelhando-se à das micas (Tabela XIII).

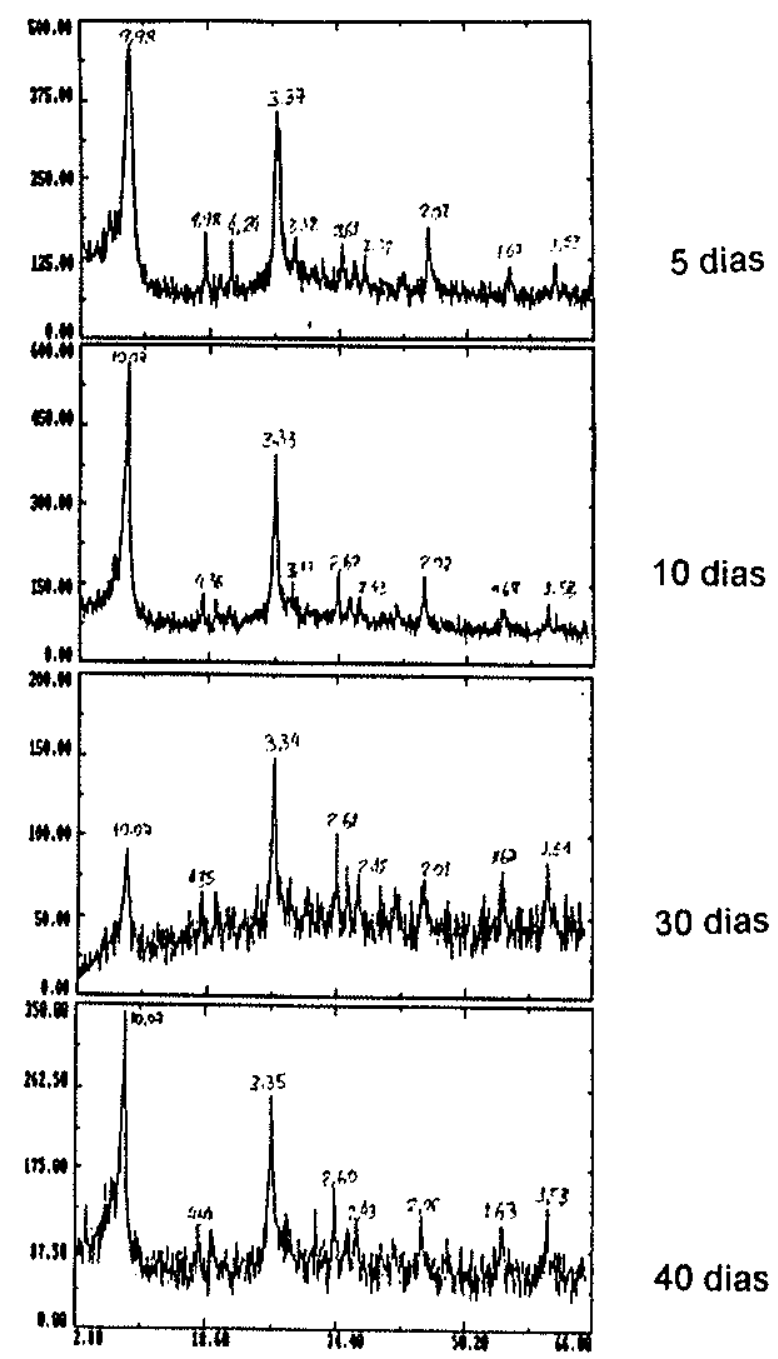

Figura 29: Difratogramas de raios $X$ das amostras de vermiculita $(M-1)$ tratadas com $\mathrm{KCl}(\mathrm{N})$. 


\begin{tabular}{|l|c|c|c|c|}
\hline \multirow{2}{*}{ İON } & Raio Iônico & \multirow{2}{*}{$\begin{array}{c}\text { scarga superf. } \\
(\mathbf{\AA})\end{array}$} & \multicolumn{2}{|c|}{ Reflexão Basal d(002) $\AA$} \\
\cline { 4 - 5 } & (carga/raio i.) & BASHAD(1950) & Dados Obtidos \\
\hline \hline $\mathbf{N a}^{+}$ & 0,98 & 1,05 & 12,56 & 12,28 \\
\hline $\mathbf{K}^{+}$ & 1,33 & 0,75 & 10,42 & 10,07 \\
\hline $\mathbf{R b}^{+}$ & 1,49 & 0,67 & 11,24 & $-\ldots-$ \\
\hline $\mathbf{C s}^{+}$ & 1,65 & 0,59 & 11,97 & $\ldots$ \\
\hline $\mathbf{M g}^{2+}$ & 0,78 & 3,08 & 14,33 & 14,03 \\
\hline $\mathbf{C a}^{2+}$ & 1,06 & 2,02 & 15,07 & - \\
\hline $\mathbf{B a}^{2+}$ & 1,43 & 1,48 & 12,56 & 12,28 \\
\hline $\mathbf{K}^{+}$ & 0,30 & 3,33 & 14,33 & 14,03 \\
\hline
\end{tabular}

Tabela XIII: Efeito dos ions trocáveis na expansão da estrutura da vermiculita (modificado de Barshad 1950).

A densidade de carga $\left(\delta_{c}\right)$ superficial citada na respectiva tabela é o principal fator que afeta diretamente o grau de hidratação do ion e corresponde à carga do ín dividida pelo valor de seu raio. Cátions bivalentes, neste caso, possuem grau de hidratação maior que os monovalentes.

- A solução de $\mathrm{MgCl}_{2} \cdot 6 \mathrm{H}_{2} \mathrm{O}(\mathrm{N})$ utilizada no tratamento da vermiculita mostrouse eficiente na troca do cálcio interfoliar, principalmente nos períodos de 30 e 40 dias. O cátion desta solução, nas condições do experimento, não conseguiu substituir por completo $\circ \mathrm{K}^{+}$, tendo liberado apenas $38 \%$ do total deste ion da posição interfoliar. O pico representativo da face (002) observado nos difratogramas de raios $X$ das amostras tratadas (Figura 30 ) indica, para o período de 5 dias, espessura de $14,2 \AA$ variando para $14,0 \AA$ nos demais periodos. 


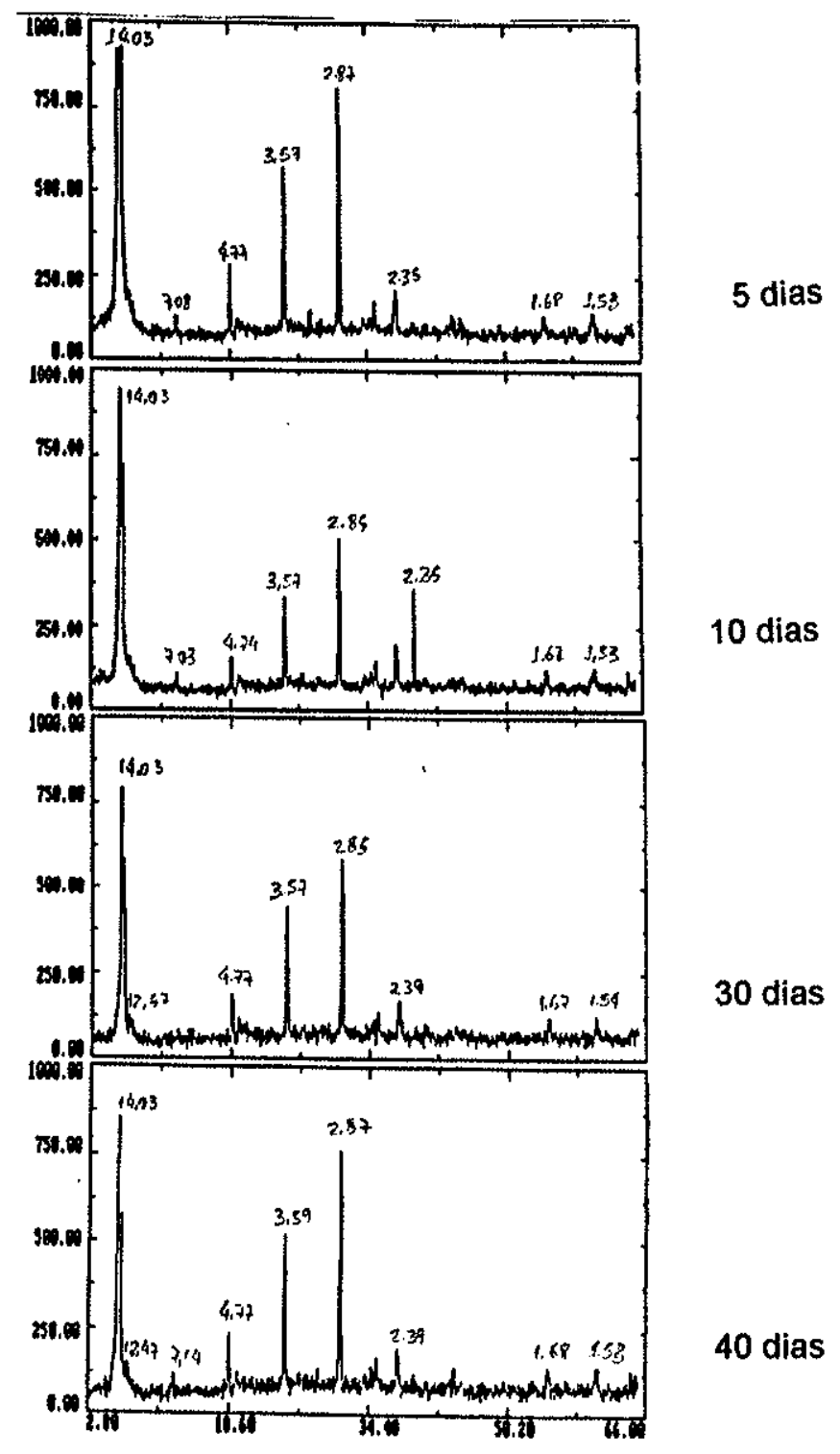

Figura 30: Difratogramas de raios $X$ das amostras de vermiculita $(M-1)$ tratadas com $\mathrm{MgCl}_{2} \cdot 6 \mathrm{H}_{2} \mathrm{O}(\mathrm{N})$.

Apesar do pequeno raio iônico do magnésio o seu grau de hidratação é relativamente alto, mantendo seu espaçamento à 14,0 A. Para Barshad (1950) a expansão da estrutura da vermiculita saturada com magnésio equivale à duas camadas moleculares de água.

- O tratamento utilizando solução de EDTA $(0,04 \mathrm{M})$ foi muito eficiente na remoção do cálcio interfoliar desde o primeiro estágio (5 dias). Por outro lado, nenhum potássio foi liberado da amostra. Isto ocorre devido à capacidade do EDTA em formar complexos com íons bivalentes, que não é o caso do potássio. 
Os difratogramas de raios $X$ (Figura 31) apresentam picos correspondentes à $d(002)$ de $14,5 \AA$ ( 30 dias), 14,3 $\AA$ (5 dias) e 14,0 $\AA$ (10 e 40 dias); e não indicam, grandes alterações na estrutura do mineral. Os picos de 12,3 $A$ que aparecem nesses difratogramas podem indicar presença de interestratificado regular $1: 1$ de vermiculita-mica, que se mantiveram na estrutura, já que o potássio não fora liberado para a solução. Por outro lado, como o EDTA é um sal trissódico, pode ser que o sódio tenha substituído, em parte, o cálcio interfoliar e gerado este pico de 12,3 A. Apesar dessa pequena substituição, grande parte do cálcio removido deve ter sido trocado por um outro íon capaz de manter a estrutura de 14,0 A intacta, como o oxônio $\left(\mathrm{H}_{3} \mathrm{O}^{+}\right)$, já que a concentração destes ions na solução de EDTA encontrava-se alta.

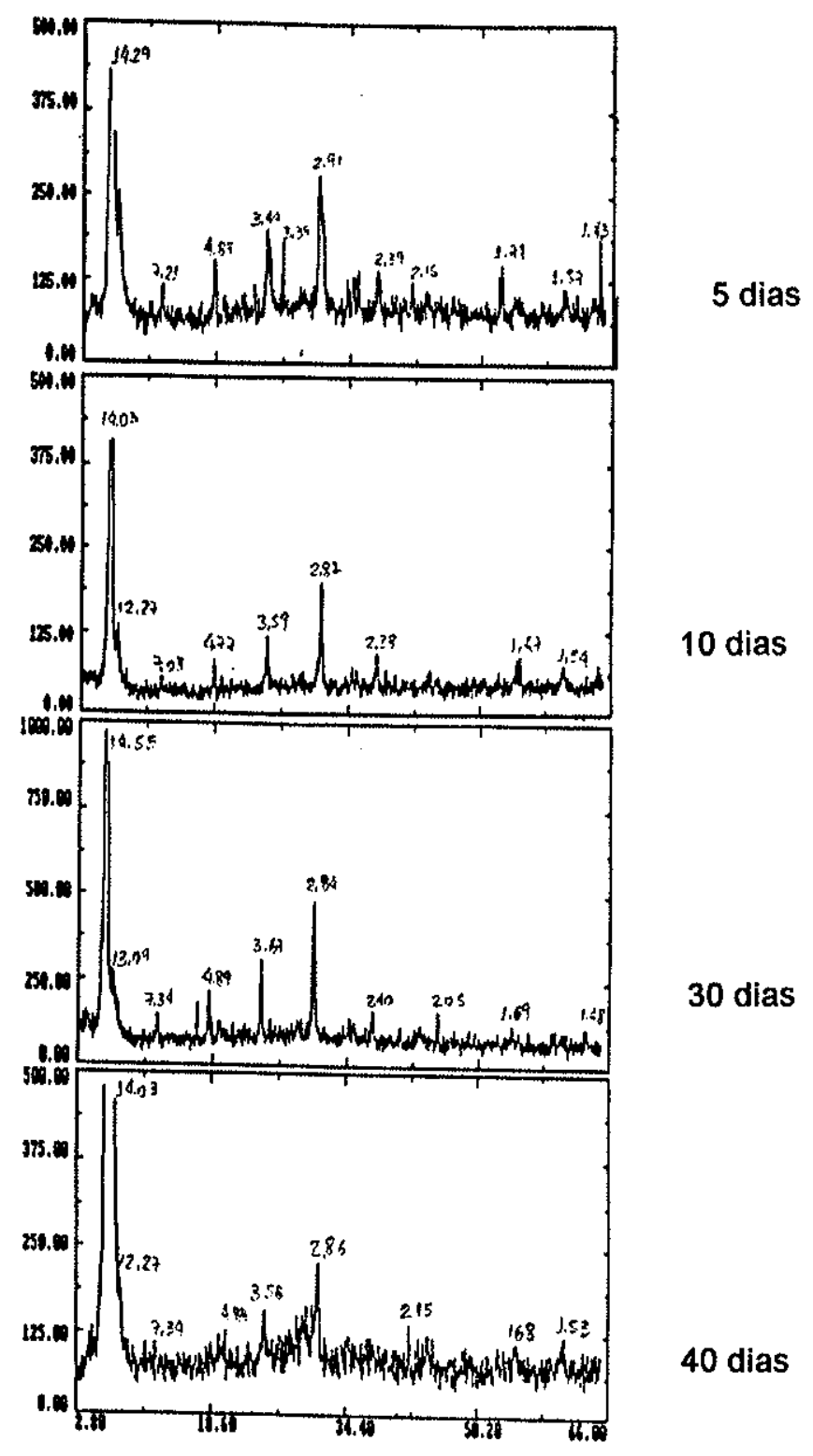

Figura 31: Difratogramas de raios $X$ das amostras de vermiculita $(M-1)$ tratadas com EDTA $(0,04 \mathrm{M})$. 
- Em todos os tratamentos houve extração de magnésio octaédrico, além de cálcio e potássio interfoliares. $O$ teor de magnésio extraído foi relativamente baixo, considerando seu elevado teor na estrutura do mineral (aproximadamente $12 \%$ ). Em média foram liberados $2,24 \%$ de magnésio no tratamento com $\mathrm{NaCl}(\mathrm{N}) ; 6,70 \%$ com $\mathrm{BaCl}_{2} \cdot 2 \mathrm{H}_{2} \mathrm{O}(\mathrm{N}) ; 2,39 \%$ com $\mathrm{KCl}(\mathrm{N})$ e $4,65 \%$ com EDTA $(0,04 \mathrm{M})$. Devido ao baixo teor de sódio na estrutura da amostra original $(0,27 \%)$ o mesmo não foi determinado nas soluções de tratamento.

A eficiência de cada tratamento também foi analisada através da comparação de gráficos que relacionam, em meq/100g, as concentrações dos ions permutados em função do tempo de troca (Figuras 32 a 36 ).

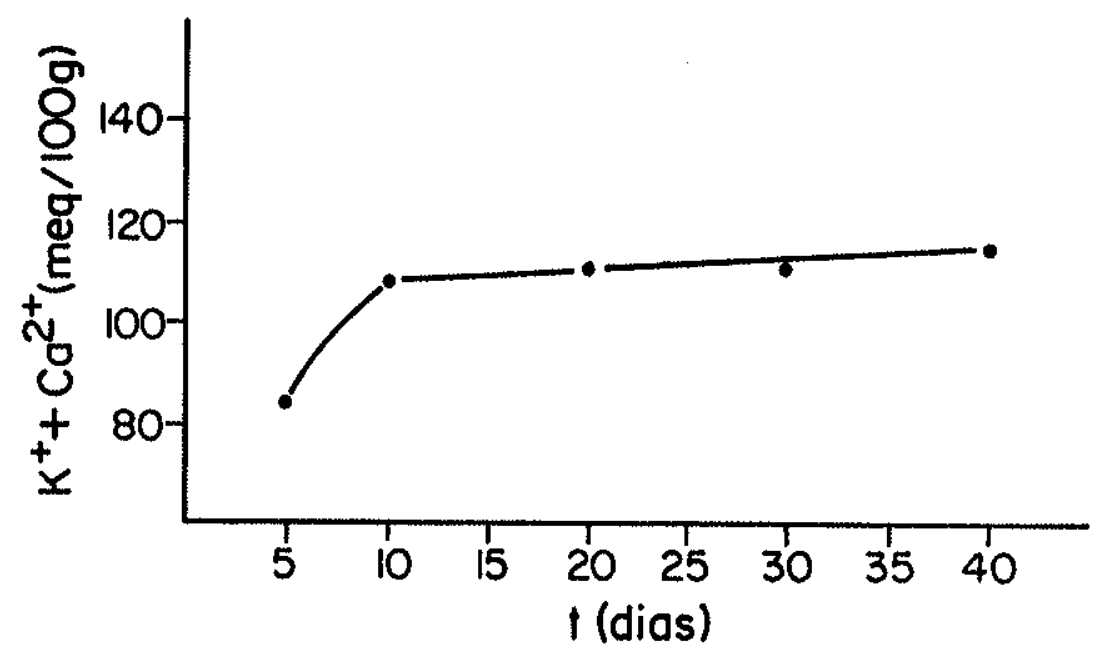

Figura 32: Projeção dos teores dos íons cálcio e potássio liberados da estrutura da vermiculita (M-1) para a solução em função do tempo de tratamento com $\mathrm{NaCl}(\mathrm{N})$. 


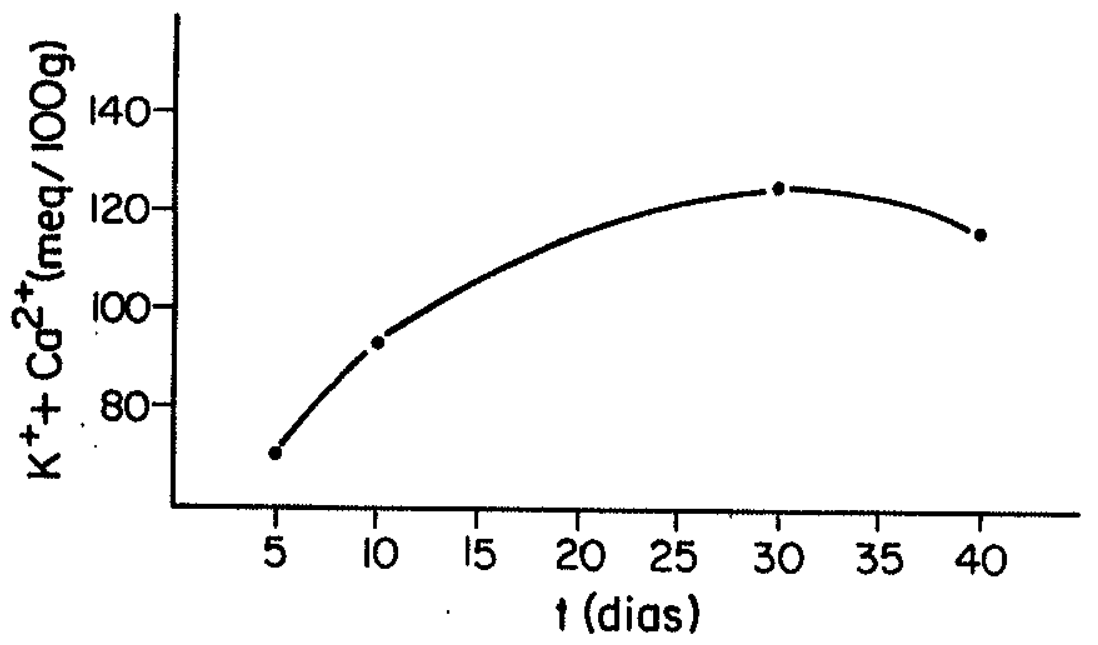

Figura 33: Projeção dos teores dos íns cálcio e potássio liberados da estrutura da vermiculita (M-1) para a solução em função do tempo de tratamento com $\mathrm{BaCl}_{2} \cdot 2 \mathrm{H}_{2} \mathrm{O}(\mathrm{N})$.

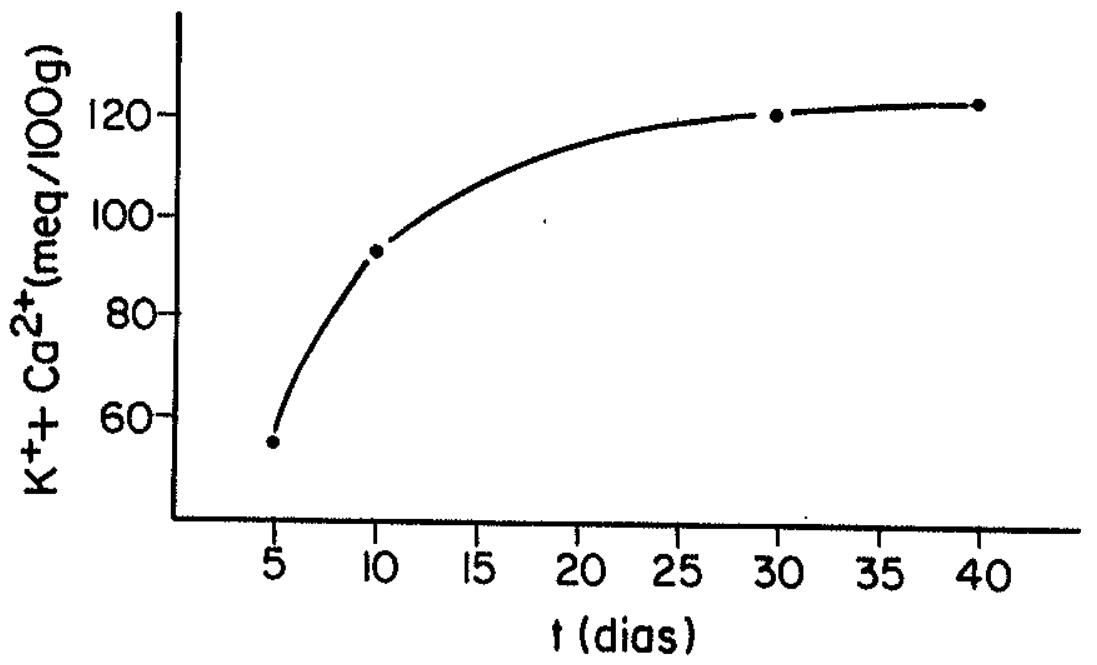

Figura 34: Projeção dos teores dos ions cálcio e potássio liberados da estrutura da vermiculita (M-1) para a solução em função do tempo de tratamento com $\mathrm{KCl}(\mathrm{N})$. 


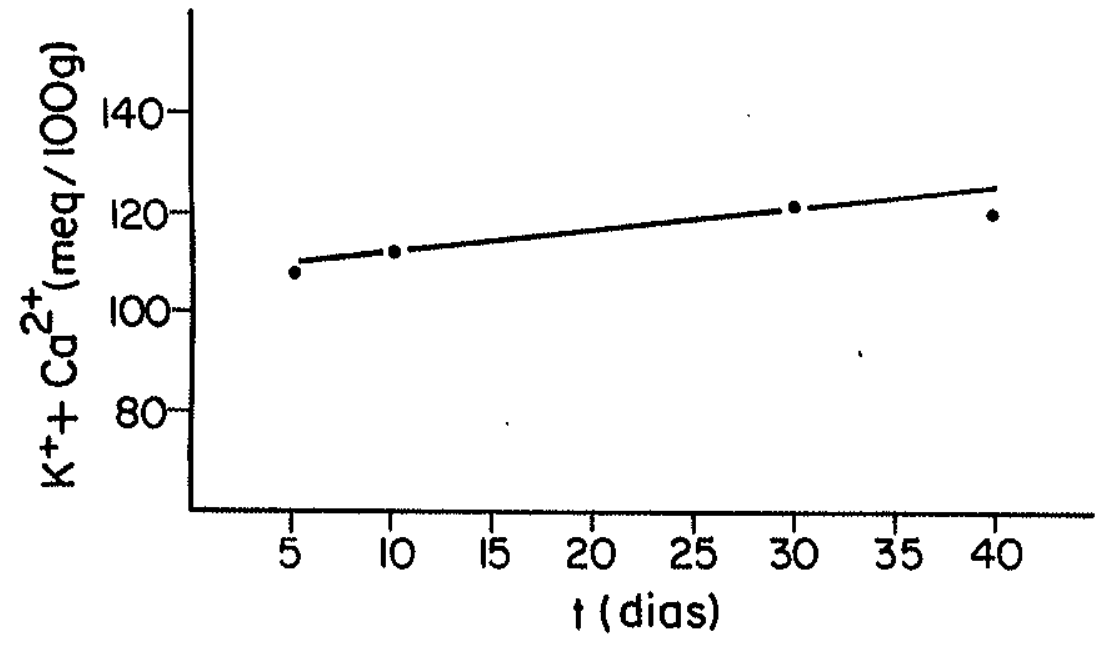

Figura 35: Projeção dos teores dos ions cálcio e potássio liberados da estrutura da vermiculita (M-1) para a solução em função do tempo de tratamento com $\mathrm{MgCl}_{2} \cdot 6 \mathrm{H}_{2} \mathrm{O}(\mathrm{N})$.

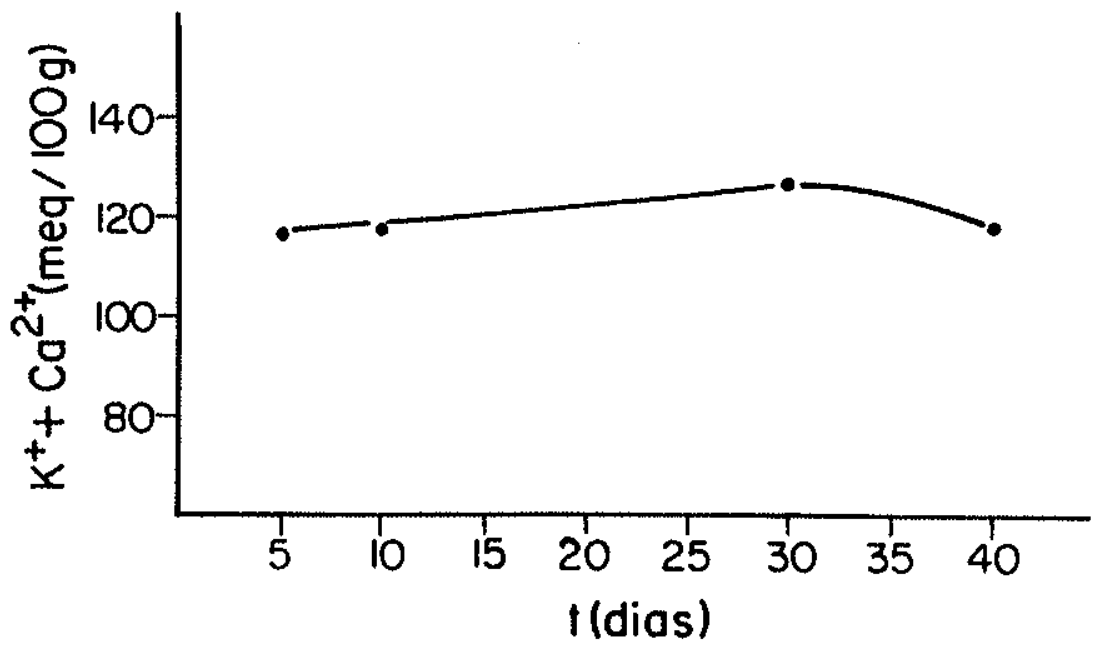

Figura 36: Projeção dos teores dos íons cálcio e potássio liberados da estrutura da vermiculita (M-1) para a solução em função do tempo de tratamento com EDTA $(0,04 \mathrm{M})$. 
A análise destes gráficos indicam que os tratamentos realizados com soluções de $\mathrm{MgCl}_{2} \cdot 6 \mathrm{H}_{2} \mathrm{O}(\mathrm{N})$ e EDTA $(0,04 \mathrm{M})$ foram os mais eficientes em relação aos demais.

Para as soluções de potássio e sódio o pico de maior intensidade de troca não se formou devido à necessidade de se prolongar os períodos dos ensaios.

De modo geral, os cátions monovalentes (sódio e potássio) foram os mais lentos no processo de troca, provavelmente devido ao raio iônico elevado, mas a eficiência de troca aumentou consideravelmente a partir de 30 dias de tratamento. Como se sabe o tamanho dos íons constitue fator decisivo na substituição, desde que a neutralidade elétrica seja mantida.

Os tratamentos efetuados neste experimento mostram a eficiência de alguns cátions em solução de serem trocados pelos da posição interfoliar da vermiculita estudada. A partir dos dados obtidos e discutidos no item anterior, conclui-se que apenas algumas amostras serão utilizadas em experimentos posteriores, justamente para aumentar a capacidade de troca destes materiais.

Os tratamentos que produziram resultados mais interessantes para o futuro uso da vermiculita como trocadora de ions inorgânicos foram os seguintes:

a) $\mathrm{BaCl}_{2} \cdot 2 \mathrm{H}_{2} \underline{\mathrm{O}}(\mathrm{N})$ : devido à facilidade do bário substituir todo potássio e parte do cálcio interfoliares, da amostra tratada.

b) EDTA $(0,04 \mathrm{M})$ : por formar complexos com ions bivalentes e os liberar da posição interfoliar da estrutura mineral, e permitir a entrada de íons oxônio.

c) $\mathrm{MgCl}_{2} \cdot 6 \mathrm{H}_{2} \mathrm{O}(\mathrm{N})$ : por trocar todo cálcio interfoliar e parte do potássio, provocando a vermiculitização das porções micáceas dos interestratificados e micas presentes na amostra.

A eficiência de troca nesses casos mostra que o potássio interfoliar da amostra original é facilmente substituído quando tratado com $\mathrm{BaCl}_{2}(\mathrm{~N})$, resultando numa amostra com bário e cálcio na posição interfoliar. Estes cátions bivalentes podem formar complexos e serem liberados da estrutura do mineral que os contém se tratados posteriormente com EDTA, e no lugar destes cátions poderão ocupar íons oxônio (Figura 37). A amostra de vermiculita com $\mathrm{H}_{3} \mathrm{O}^{+}$no espaço interfoliar pode oferecer maior capacidade de troca por qualquer outro ín, principalmente metais pesados em solução. A segunda etapa deste tratamento se ocupa, exatamente, em realizar esta troca. 


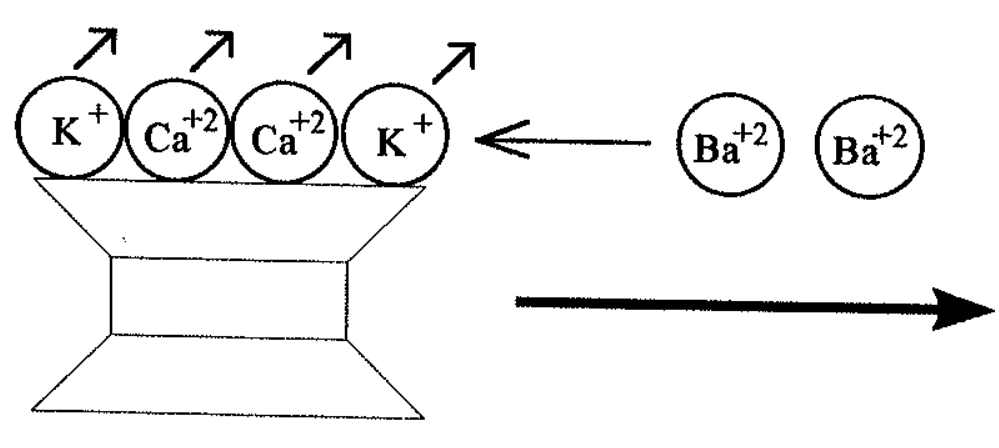

(1)

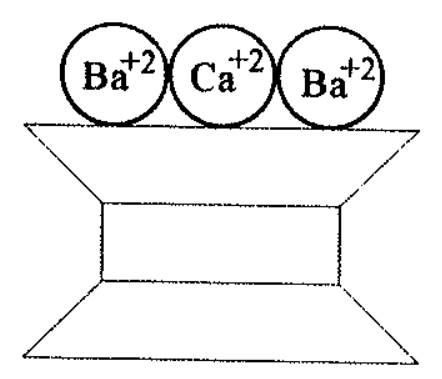

(2)

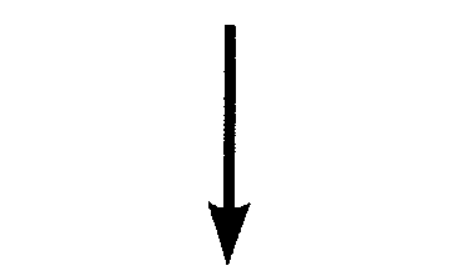

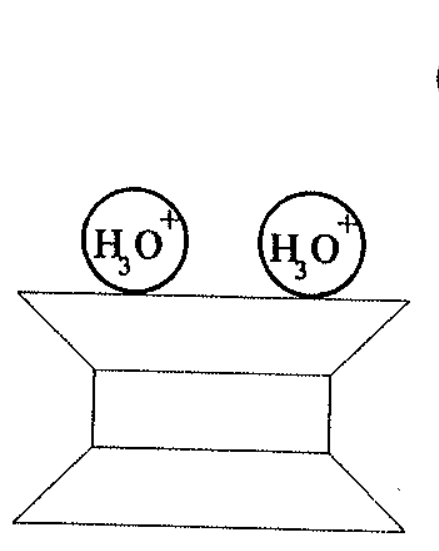

(4)
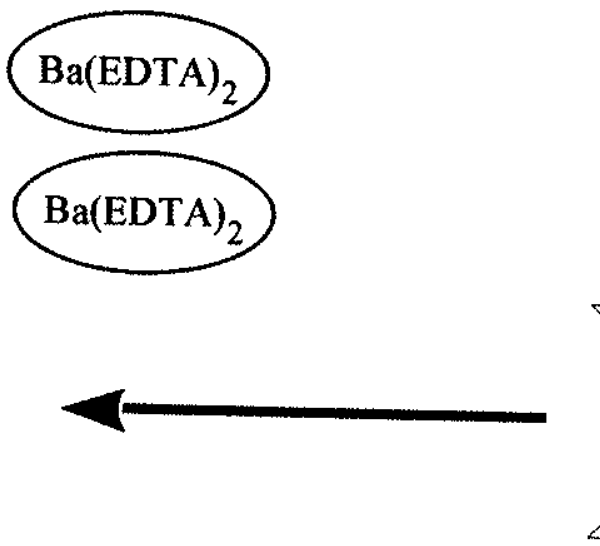

-

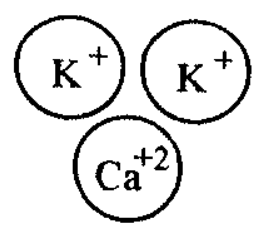

EDTA
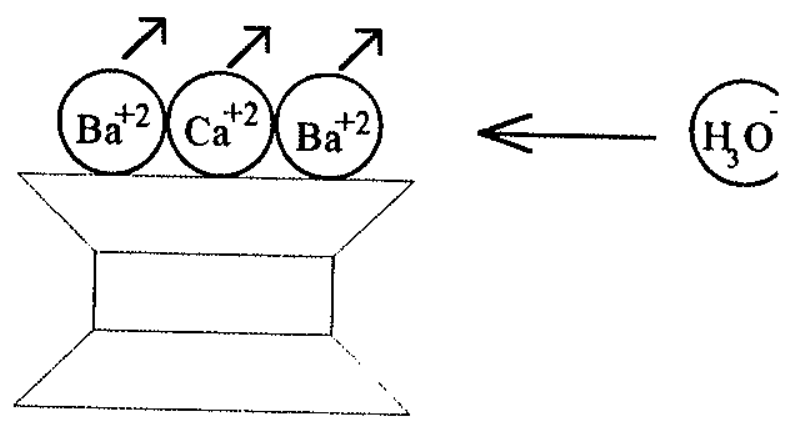

(3)

(1) Amostra original, contendo $\mathrm{Ca}^{2+} \mathrm{e} \mathrm{K}^{+}$na posição interfoliar tratada com solução de $\mathrm{Ba}^{2+}$;

(2) Amostra saturada com $\mathrm{Ba}^{2+}$ da solução e $\mathrm{Ca}^{2+}$ remanescente da composição original;

(3) Tratamento com EDTA para formação de complexo com ions bivalentes;

(4) Amostra com $\mathrm{H}_{3} \mathrm{O}^{+}$ocupando a posição interfoliar.

Figura 37: Representação esquemática de troca iônica realizada na obtenção de vermiculita com $\mathrm{H}_{3} \mathrm{O}^{+}$. 
- 2a Fase

O objetivo deste ensaio é o de promover a transformação de vermiculita com $\mathrm{Ba}^{2+}$ em vermiculita com $\mathrm{H}_{3} \mathrm{O}^{+}$, através de tratamentos com EDTA $(0,04 \mathrm{M})$.

\section{MATERIAIS}

- Vermiculita com Ba ${ }^{2+}$ (amostra VBa-40);

- Solução de EDTA $(0,04 \mathrm{M})$.

\section{CONDICÕES EXPERIMENTAIS}

$$
\begin{aligned}
& M_{i(\mathrm{VBa}-40)}=1,0000 \mathrm{~g} ; \\
& V_{\text {EDTA }}=100 \mathrm{~mL} \\
& T=\text { ambiental }\left(\sim 25^{\circ} \mathrm{C}\right) \\
& \mathrm{t}=5 \text { dias }(120 \mathrm{~h})
\end{aligned}
$$

\section{PROCEDIMENTO}

- Transferir em béquer de $400 \mathrm{~mL} 1,0000 \mathrm{~g}$ de VBa-40;

- Adicionar $100 \mathrm{~mL}$ de solução de EDTA $(0,04 \mathrm{M})$;

- Agitar a mistura frequentemente e deixar à temperatura ambiente $\left(\sim 25^{\circ} \mathrm{C}\right)$ por $120 \mathrm{~h}$;

- Filtrar a solução e recolher em balão volumétrico de $200 \mathrm{~mL}$;

- Analisar química e mineralógicamente, respectivamente a solução e o sólido retido no filtro.

\section{RESULTADOS}

O teor obtido para o bário lixiviado é de $6,7 \%$, que equivale a 97,6 meq $\mathrm{Ba} / 100 \mathrm{~g}$ de amostra.

$O$ difratograma de raios $X$ da amostra tratada (Figura 38 ), em comparação com o da amostra de vermiculita com $\mathrm{Ba}^{2+}(\mathrm{VBa}-40)$ indica mudança na reflexão basal - que aumentou de 12,3 para $14,3 \AA$ - provavelmente devido à substituição de bário por oxônio da solução lixiviante $\left(\mathrm{EDTA} / \mathrm{H}_{3} \mathrm{O}^{+}\right)$. 


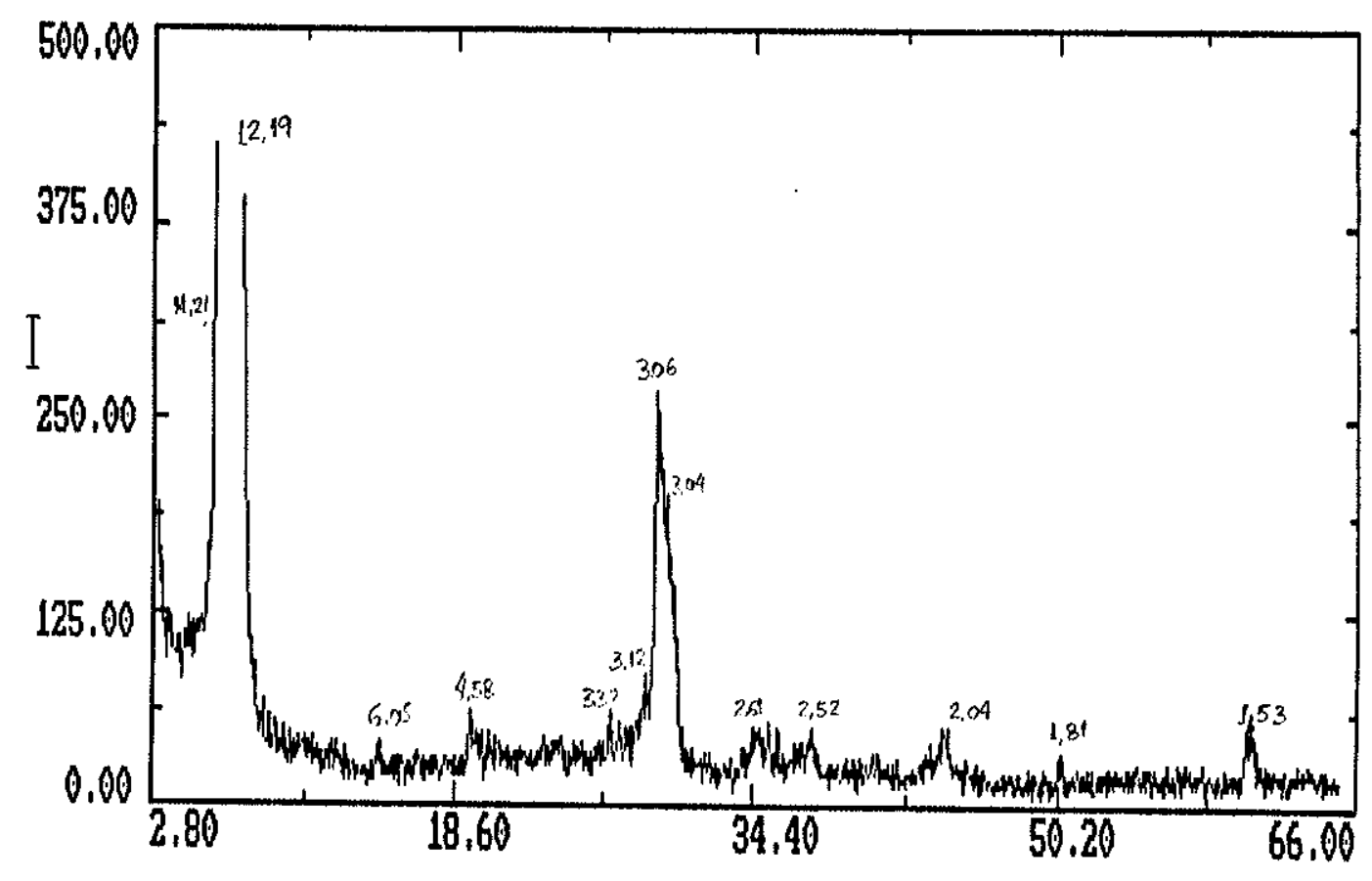

Figura 38: Difratograma de raios $\mathrm{X}$ da amostra VBa-40 tratada com EDTA $(0,04 M)$.

A partir dos dados obtidos verifica-se a eficiência do tratamento em desenvolver vermiculita com $\mathrm{H}_{3} \mathrm{O}^{+}$. Esta, por sua vez, será utilizada em ensaios posteriores, juntamente com outros, para estudo comparativo do grau de eficiência do poder de troca com metais pesados em solução. A amostra resultante deste experimento foi catalogada de $\mathrm{VH}_{3} \mathrm{O}$. 
O objetivo desta etapa é de quantificar os cátions fixados e/ou trocados pelos tratamentos salinos da $1^{a}$ fase nas amostras estudadas.

Foram escolhidas as amostras VK-40 e VNa-40 devido à facilidade e rapidez que envolvem as análises de seus cátions constituintes (potássio e sódio).

\section{MATERIAIS}

- Vermiculitas pré-tratadas na 1 a fase (VK-40 e VNa-40);

- Solução de $\mathrm{HCl}(\mathrm{M})(83,33 \mathrm{~mL}$ de $\mathrm{HCl}$ concentrado diluído em $1000 \mathrm{~mL}$ de água destilada).

\section{DADOS EXPERIMENTAIS}

$M_{i}$ amostra $=0,5000 \mathrm{~g}$;

$\mathrm{V}_{\mathrm{i}} \mathrm{HCl}=100 \mathrm{~mL}$;

$\mathrm{T}=40^{\circ} \mathrm{C}$;

$t=72 h$.

\section{PROCEDIMENTO}

- Transferir $0,5000 \mathrm{~g}$ de cada amostra em respectivos béqueres de $300 \mathrm{~mL}$;

- Acrescentar $100 \mathrm{~mL}$ de solução de $\mathrm{HCl}$ e agitar frequentemente;

- Aquecer à $40^{\circ} \mathrm{C}$ por 24 horas.

- Recolher as soluções em balões volumétricos de $200 \mathrm{~mL}$ após filtração com papel de filtração lenta;

- Devolver as amostras retidas nos filtros para os béqueres anteriores repondo mais $100 \mathrm{~mL}$ de solução de $\mathrm{HCl}$;

- Aquecer e agitar novamente a mistura;

- Recolher novamente as soluções em balões volumétricos de $200 \mathrm{~mL}$ após filtração;

- Repetir os procedimentos anteriores à filtração mais uma vez;

- Após a última filtração, analisar as soluções contidas nos balões volumétricos. 


\section{RESULTADOS}

Os teores de sódio e potássio lixiviados das amostras pré-tratadas encontram-se na tabela XIV.

\begin{tabular}{|c|c|c|}
\hline AMOSTRA & Elementos lixiviados & Concentracão na sol. (\%) \\
\hline VK-40 & $\mathbf{N a}^{+}$ & 2,22 \\
\hline VNa-40 & $\mathbf{K}^{+}$ & 4,28 \\
\hline
\end{tabular}

Tabela XIV: Teores de $\mathrm{Na}^{+}$e $\mathrm{K}^{+}$removidos da estrutura das amostras VK-40 e VNa-40 através de lixiviação com solução clorídrica (M).

Os valores dos ions lixiviados das amostras aproximam-se muito daqueles calculados anteriormente $\left(2,66\right.$ para $\mathrm{Na}^{+} e$ 4,79 para $\left.\mathrm{K}^{+}\right)$na primeira fase deste experimento.

Os cálculos para a determinação da concentração dos íons trocadores em solução foram efetuados a partir da equação:

$$
C_{i}=\frac{M e \times E q}{1000}
$$

onde,

$C_{i}=$ concentração esperada para o ion trocador na solução;

$M e=$ cátions lixiviados (cálcio e potássio) em meq/100g de amostra;

$\mathrm{Eq}=$ equivalente-grama do elemento considerado.

Para exemplicar o uso desta equação, toma-se o valor dos íons cálcio e potássio lixiviados durante o tratamento salino da primeira fase ( por exemplo, $\mathrm{VNa}-40=115,84 \mathrm{meq} / 100 \mathrm{~g}$ ) para calcular a quantidade equivalente de íons sódio que os substituíram na estrutura. Logo, o valor de Eq será o número de equivalente-grama de $\mathrm{Na}^{+}(22,99)$. Efetuando-se o cálculo tem-se o valor em \% dos ions $\mathrm{Na}^{+}$que teriam sido retidos na estrutura da vermiculita e posteriormente liberados da mesma, através do tratamento ácido. 
Como se pode notar, os valores não coincidiram mas se aproximaram bastante. Portanto, fica evidente que analisando somente os cátions lixiviados da estrutura do mineral para a solução, o seu valor pode ser considerado equivalente à concentração do cátion trocado e retido na mesma.

\section{- EXPERIÉNCIA C (3 fases): troca com metais pesados}

Neste experimento foram selecionadas amostras de vermiculita crua (M-1) e pré-tratadas ( $\mathrm{VMg}-30$ e $\mathrm{VH}_{3} \mathrm{O}$ ) com o objetivo de testar a capacidade de cada amostra em fixar os metais pesados das soluções.

Foram preparadas inicialmente, três soluções contendo, respectivamente, cobre, chumbo e níquel. Numa segunda fase utilizou-se amostra de efluente industrial de uma indústria de cromação.

A terceira fase consistiu no estudo de regeneração das vermiculitas saturadas com metais pesados.

\section{- 1a Fase}

Retenção de metais pesados de soluções preparadas no laboratório.

\section{MATERIAIS}

- Vermiculita crua fina (M-1);

- Amostras pré-tratadas (VMg-30 e $\mathrm{VH}_{3} \mathrm{O}$ );

- Soluções:

a) $\mathrm{Ni}\left(\mathrm{NO}_{3}\right)_{2} \cdot 6 \mathrm{H}_{2} \mathrm{O}(0,25 \mathrm{~N})$;

b) $\mathrm{Cu}\left(\mathrm{CH}_{3} \mathrm{COO}\right)_{2} \cdot \mathrm{H}_{2} \mathrm{O}(0,25 \mathrm{~N})$;

c) $\mathrm{Pb}\left(\mathrm{NO}_{3}\right)_{2}(0,25 \mathrm{~N})$. 


\section{CONDICÕES EXPERIMENTAIS}

$\mathrm{M}_{\mathrm{i}}$ amostra $=0,3500 \mathrm{~g}$

$\mathrm{V}_{\mathrm{i} \text { solução }}=50 \mathrm{~mL}$

$\mathrm{T}=40^{\circ} \mathrm{C}$

$\mathrm{t}=240 \mathrm{~h}$

\section{PROCEDIMENTO}

- Pesar $0,3500 \mathrm{~g}$ de cada amostra e transferir para béqueres de $100 \mathrm{~mL}$;

- Adicionar $50 \mathrm{~mL}$ da solução;

- Agitar as misturas e aquecê-las à $40^{\circ} \mathrm{C}$ em banho termostatizado;

- Efetuar acompanhamento com brancos;

- No final de 10 dias, filtrar as misturas e recolher as soluções em balões volumétricos de $200 \mathrm{~mL}$;

- Analisar quimicamente as soluções e mineralogicamente as amostras retidas nos filtros.

\section{RESULTADOS}

Os resultados das análises químicas encontram-se na tabela XV.

\begin{tabular}{|c|c|c|c|c|c|c|}
\hline \multirow{2}{*}{$\begin{array}{l}\text { soluções } \\
(0,25 \mathrm{~N}) \\
\end{array}$} & \multirow{2}{*}{$\begin{array}{c}{[\text { metal }]_{\text {inicial }}} \\
(\mathrm{ppm})\end{array}$} & \multirow[t]{2}{*}{ amostra } & \multicolumn{2}{|c|}{ [metal retido] na amostra } & \multirow{2}{*}{$\begin{array}{c}\mathrm{pH} \\
\text { inicial } \\
\end{array}$} & \multirow{2}{*}{$\begin{array}{l}\mathrm{pH} \\
\text { final }\end{array}$} \\
\hline & & & $(\mathrm{ppm})$ & $\mathrm{meg} / 100 \mathrm{~g}$ & & \\
\hline & & M-1 & 175 & 78,67 & 5,28 & 5,24 \\
\hline \multirow[t]{3}{*}{$\mathrm{Cu}(\mathrm{Ac})_{2} \cdot \mathrm{H}_{2} \mathrm{O}$} & 3925 & $\mathrm{VMg}-30$ & 525 & 235,73 & 5,30 & 5,14 \\
\hline & & $\mathrm{VH}_{3} \mathrm{O}$ & 600 & 269,43 & 5,25 & 5,19 \\
\hline & & M-1 & 1083 & 144,79 & 4,15 & 4,60 \\
\hline \multirow[t]{3}{*}{$\mathrm{Pb}\left(\mathrm{NO}_{3}\right)_{2}$} & 18333 & $\mathrm{VMg}-30$ & 1083 & 144,79 & 4,10 & 4,40 \\
\hline & & $\mathrm{VH}_{3} \mathrm{O}$ & 1083 & 144,79 & 3,90 & 4,15 \\
\hline & & M-1 & 167 & 81,05 & 6,30 & 5,25 \\
\hline \multirow[t]{2}{*}{$\mathrm{Ni}\left(\mathrm{NO}_{3}\right)_{2} \cdot 6 \mathrm{HO}$} & 4750 & $\mathrm{VMg}-30$ & 200 & 97,28 & 6,00 & 5,00 \\
\hline & & $\mathrm{VH}_{3} \mathrm{O}$ & 500 & 243,07 & 4,20 & 3,70 \\
\hline
\end{tabular}

Tabela XV: Teores de cátions metálicos na solução original e os retidos na estrutura das amostras estudadas $\left(\mathrm{M}-1, \mathrm{VMg}-30, \mathrm{VH}_{3} \mathrm{O}\right)$, após respectivos tratamentos. São dados também, os valores dos $\mathrm{pHs}$ inicial e final de cada sistema. 
A partir dos resultados analíticos observa-se que o chumbo - que possui raio iônico elevado $(1,20 \AA)$ e se apresenta altamente concentrado na solução (18333 $\mathrm{ppm}$ ) - é o metal que, quantitativamente, ficou mais retido em todas as amostras, independentemente da natureza do cátion interfoliar de cada amostra.

A vermiculita com $\mathrm{H}_{3} \mathrm{O}^{+}\left(\mathrm{VH}_{3} \mathrm{O}\right)$ retém cobre, níquel e chumbo eficazmente. A vermiculita com $\mathrm{Mg}^{2+}(\mathrm{VMg}-30)$ apresenta também bons resultados, principalmente em relação à fixação de cobre e chumbo.

A vermiculita natural (M-1) consegue adsorver bem 0 chumbo $e$ razoavelmente o níquel e o cobre.

Este comportamento diversificado de troca catiônica está intimamente ligado às caracterísiticas dos metais pesados em solução. Nota-se, por exemplo, que quanto maior o grau de hidratação do cátion interfoliar do mineral, em relação ao do cátion da solução, maior é a sua facilidade de troca. Como já foi explicado, o grau de hidratação de cada ion está diretamente relacionado com a sua densidade superficial de carga $\left(\delta_{\mathrm{C}}=\right.$ carga iônica / raio iônico) (Tabela XVI).

\begin{tabular}{|c|c|c|c|c|c|}
\hline \multicolumn{2}{|c|}{$\delta_{\mathrm{c}}$ (cátion interfoliar) das amostras } & \multicolumn{3}{|c|}{$\delta_{\mathrm{c}}$ (cátion da solucão) } \\
\hline $\mathrm{M}-1$ & $\mathrm{VMg}-30$ & $\mathrm{VH}_{3} \mathrm{O}$ & $\mathrm{Cu}^{2+}$ & $\mathrm{Pb}^{2+}$ & $\mathrm{Ni}^{2+}$ \\
\hline $\mathrm{Ca}^{2+}$ & $\mathrm{Mg}^{2+}$ & $\mathrm{H}_{3} \mathrm{O}^{+}$ & & & \\
\hline \hline 2,02 & 3,03 & 3,33 & 2,08 & 1,67 & 2,90 \\
\hline
\end{tabular}

Tabela XVI: Valores de $\delta_{C}$ dos cátions envolvidos no processo de troca do experimento $C$ ( $1^{a}$ fase $)$.

A facilidade de troca pode ser afetada também pelo $\mathrm{pH}$ da solução uma vez que a presença de íons oxônios implica na sua competição com os demais cátions. Nos tratamentos em questão a faixa de $\mathrm{pH}$ variou de, aproximadamente, 4,0 a 6,0 e esta, devido às altas concentrações dos metais, não afetou, de modo significativo, a reação de troca destes com os ions interfoliares da vermiculita. 
Os difratogramas de raios $X$ (Figuras 39 a 41) apresentam um mesmo comportamento de difração para as diferentes amostras tratadas com solução de chumbo, indicando, possivelmente, um mesmo tipo de eficiência de troca. A reflexão basal $d(002)$ das amostras sofreu uma diminuição de 14,0 para 13,6 A devido ao raio iônico elevado do chumbo $(1,2 \AA)$.

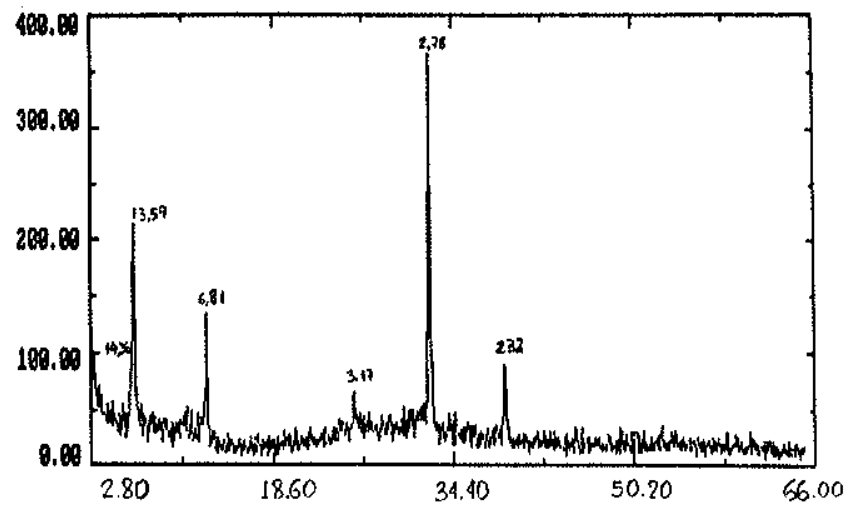

Figura 39: Difratograma de raios $X$ da amostra $M-1$ tratada com solução de $\left.\mathrm{Pb}(\mathrm{NO})_{3}\right)_{2}$.

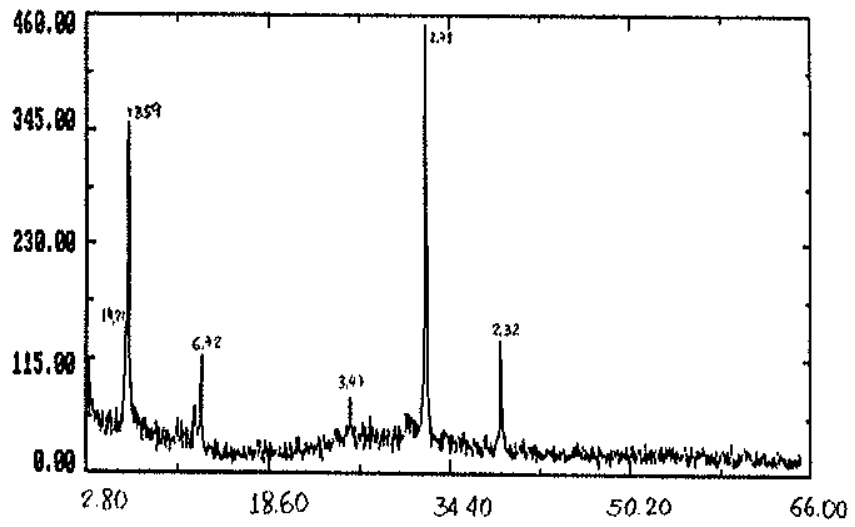

Figura 40: Difratograma de raios $X$ da amostra VMg-30 tratada com solução de $\left.\mathrm{Pb}(\mathrm{NO})_{3}\right)_{2}$.

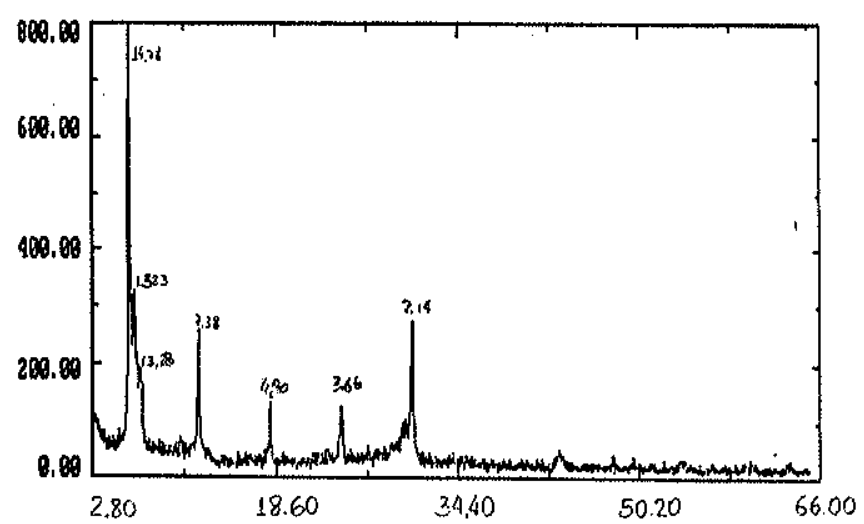

Figura 41: Difratograma de raios $\mathrm{X}$ da amostra $\mathrm{VH}_{3} \mathrm{O}$ tratada com solução de $\left.\mathrm{Pb}(\mathrm{NO})_{3}\right)_{2}$. 
Entre as amostras tratadas com solução de níquel, observa-se nas figuras 42 , 43 e 44, que a vermiculita magnesiana ( $\mathrm{VMg}-30)$ e a saturada com oxônio $\left(\mathrm{VH}_{3} \mathrm{O}\right)$ possuem, no geral, um mesmo comportamento de difração de raios $\mathrm{X}$, concordando com o que diz respeito à sua eficiência no processo de troca.

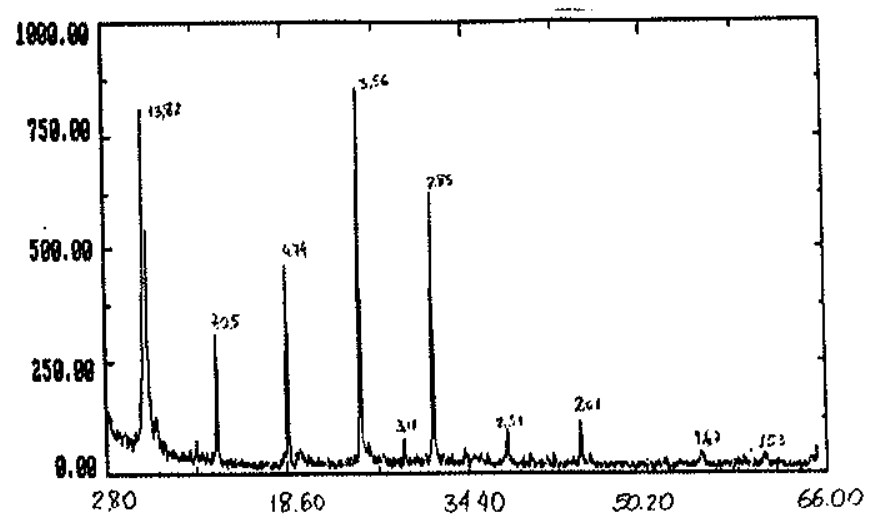

Figura 42: Difratograma de raios $X$ da amostra $M-1$ tratada com solução de $\mathrm{Ni}\left(\mathrm{NO}_{3}\right)_{2} \cdot 6 \mathrm{H}_{2} \mathrm{O}$.

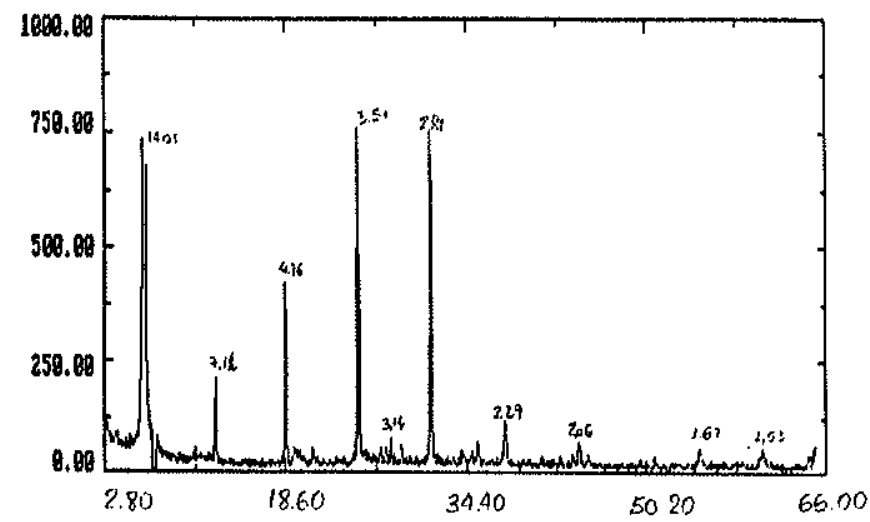

Figura 43: Difratograma de raios $X$ da amostra VMg-30 tratada com solução de $\mathrm{Ni}\left(\mathrm{NO}_{3}\right)_{2} \cdot 6 \mathrm{H}_{2} \mathrm{O}$.

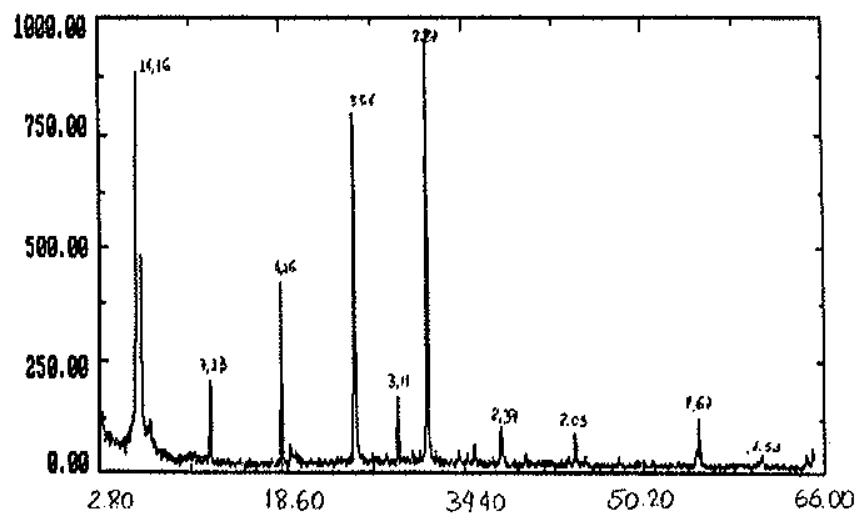

Figura 44: Difratograma de raios $\mathrm{X}$ da amostra $\mathrm{VH}_{3} \mathrm{O}$ tratada com solução de $\mathrm{Ni}\left(\mathrm{NO}_{3}\right)_{2} \cdot 6 \mathrm{H}_{2} \mathrm{O}$. 
Os difratogramas de raios $X$ (Figuras 45 a 47) das amostras saturadas com cobre mostram comportamento semelhante ao tratamento anterior com níquel. Isto se deve principalmente pelas características dos ions níquel e cobre que se assemelham muito, pois além de ambos serem bivalentes, o primeiro possui raio iônico igual a 0,7 A e o segundo, a 0,9 A.

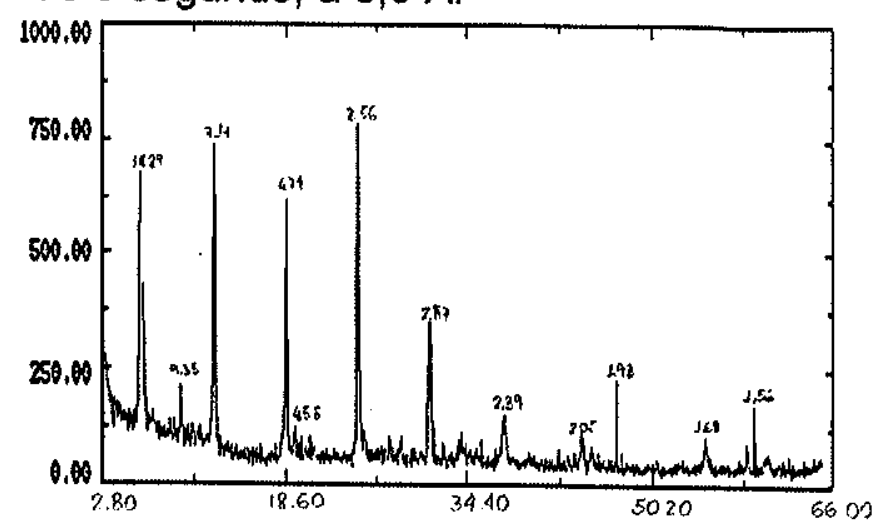

Figura 45: Difratograma de raios $X$ da amostra $M-1$ tratada com solução de $\mathrm{Cu}(\mathrm{Ac})_{2} \cdot \mathrm{H}_{2} \mathrm{O}$.

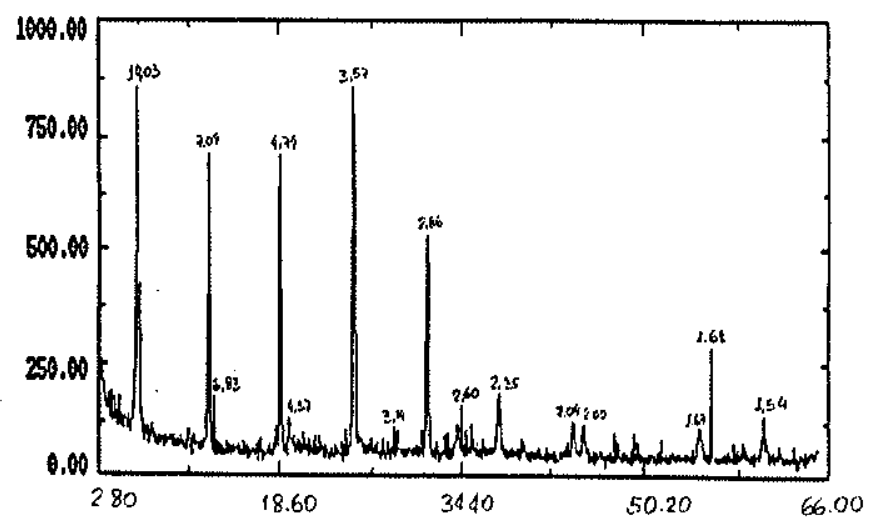

Figura 46: Difratograma de raios $X$ da amostra VMg-30 tratada com solução de $\mathrm{Cu}(\mathrm{Ac})_{2} \cdot \mathrm{H}_{2} \mathrm{O}$.

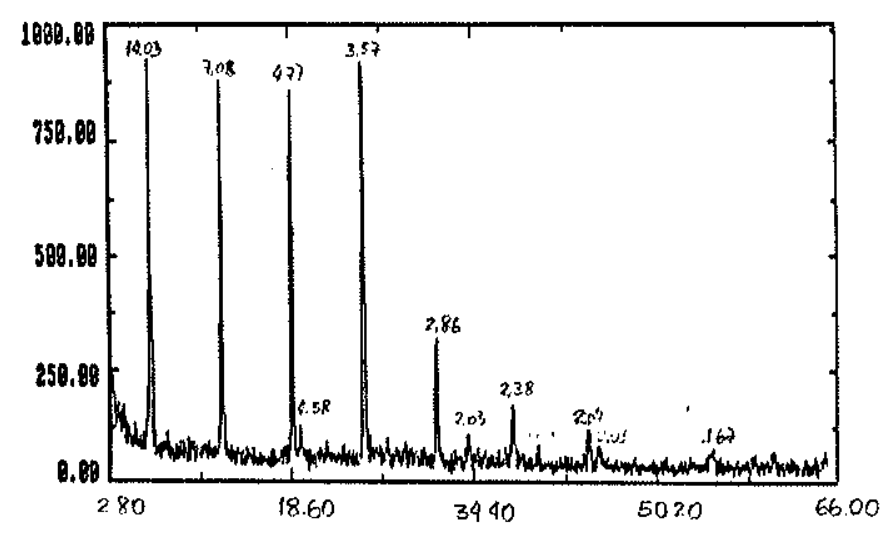

Figura 47: Difratograma de raios $\mathrm{X}$ da amostra $\mathrm{VH}_{3} \mathrm{O}$ tratada com solução de $\mathrm{Cu}(\mathrm{Ac})_{2} \cdot \mathrm{H}_{2} \mathrm{O}$. 
Retenção de metais pesados contidos em efluente industrial.

\section{MATERIAIS}

- Amostras pré-tratadas $\left(\mathrm{VMg}-30, \mathrm{VH}_{3} \mathrm{O}\right)$;

- Amostra crua fina (M-1);

- Solução de efluente industrial (indústria de cromação).

\section{CONDICÕES EXPERIMENTAIS}

$M_{i}$ amostra $=0,5000 \mathrm{~g} ;$

$V_{i}$ solução $=50 \mathrm{~mL}$;

$\mathrm{T}=25$ e $40^{\circ} \mathrm{C}$;

$\mathrm{t}=6$ e $120 \mathrm{~h}$;

$\mathrm{pH}=$ controle no início e fim dos experimentos.

\section{PROCEDIMENTO}

- Pesar 0,5000 g de cada amostra em duplicata e transferir para béqueres de $100 \mathrm{~mL}$;

- Adicionar em cada béquer $50 \mathrm{~mL}$ de amostra de efluente industrial, e fazer imediatamente a leitura do $\mathrm{pH}$;

- Agitar as misturas e separar as duplicatas de forma a se obterem duas séries de experimentos; manter uma delas à temperatura ambiente $\left(\sim 25^{\circ} \mathrm{C}\right)$ por 6 horas e a outra à $40^{\circ} \mathrm{C}$ por 120 horas;

- No final de cada experimento, ler o pH das misturas e filtrar;

- Recolher as soluções em balões volumétricos de $200 \mathrm{~mL}$ e, analisá-las quimicamente. 


\section{RESULTADOS}

A tabela XVII traz os resultados das análises químicas realizadas nesta etapa.

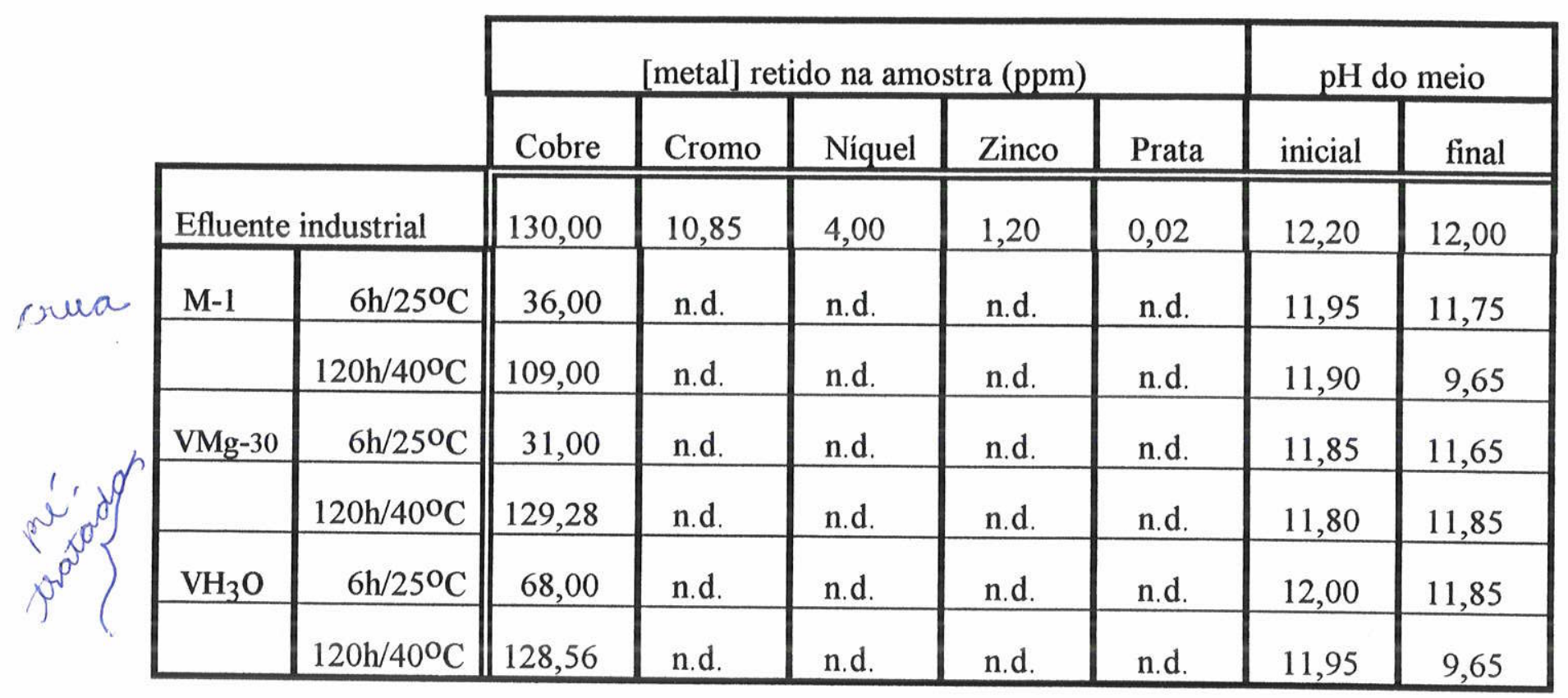

Tabela XVII: Concentrações dos íons metálicos do efluente industrial retidos nas amostras estudadas ( $\mathrm{M}-1, \mathrm{VMg}-30$ e $\left.\mathrm{VH}_{3} \mathrm{O}\right)$. São relacionados, também, os valores dos $\mathrm{pHs}$ inicial e final de cada sistema.

Os resultados analíticos mostram que aumentando o período $(>6 \mathrm{~h})$ e a temperatura $\left(>25^{\circ} \mathrm{C}\right)$ do tratamento, a reação de troca ocorre com maior intensidade. Percebe-se, também, que a remoção do cobre predomina sobre os demais metais, provavelmente, devido à sua maior concentração na solução original.

As amostras saturadas com magnésio ( $\mathrm{VMg}-30)$ e com oxônio $\left(\mathrm{VH}_{3} \mathrm{O}\right)$ foram as que conseguiram reter cerca de $99 \%$ do cobre em solução. A troca iônica é mais eficaz nestas amostras, talvez, devido à presença de cátions fortemente hidratados (magnésio e oxônio, respectivamente) na posição interfoliar.

Como os experimentos ocorreram em meio básico, praticamente não houve a interferência dos íons $\mathrm{H}^{+}$no processo de troca catiônica. 
Os demais cátions não foram detectados nas amostras provavelmente por se encontrarem fracamente concentradas nas soluções.

\section{- $3^{\mathrm{a}}$ Fase}

Regeneração da vermiculita saturada com metais pesados.

\section{MATERIAIS}

- Amostras saturadas com soluções de metais pesados da primeira fase:

$$
\begin{aligned}
& \mathrm{M}-1+\mathrm{Pb}^{2+}=\mathrm{M} 1-\mathrm{Pb} \\
& \mathrm{VH}_{3} \mathrm{O}+\mathrm{Cu}^{2+}=\mathrm{VH}-\mathrm{Cu} \\
& \mathrm{VH}_{3} \mathrm{O}+\mathrm{Ni}^{2+}=\mathrm{VH}-\mathrm{Ni}
\end{aligned}
$$

-Amostras saturadas com efluente industrial (solução da segunda fase):

$$
\mathrm{VH}_{3} \mathrm{O}+\mathrm{Cu}^{2+}=\mathrm{VH}-\mathrm{Cu}\left(2^{\mathrm{a}} \text { fase }\right)
$$

-Solução de EDTA $(0,04 \mathrm{M})$.

\section{CONDICÕES EXPERIMENTAIS}

$M_{i}$ amostra $=0,2200 \mathrm{mg}$;

$\mathrm{V}_{\mathrm{i}}=50 \mathrm{~mL}$;

$\mathrm{T}=$ ambiente $\left(\sim 25^{\circ} \mathrm{C}\right)$;

$t=96 h$.

\section{PROCEDIMENTO}

- Pesar as amostras e transferir para béqueres de $100 \mathrm{~mL}$;

- Adicionar em cada béquer $50 \mathrm{~mL}$ de solução de $\operatorname{EDTA}(0,04 \mathrm{M})$ e, imediatamente, ler o $\mathrm{pH}$ das misturas;

- Agitar frequentemente e manter por $120 \mathrm{~h}$ à temperatura ambiente;

- No final do período, ler o $\mathrm{pH}$ das misturas e filtrar;

- Recolher as soluções em balões volumétricos de $200 \mathrm{~mL}$ e, analisá-las quimicamente;

- Analisar mineralogicamente as amostras retidas nos filtros por difração de raios $\mathrm{X}$. 


\section{RESULTADOS}

Os resultados analíticos desta etapa de experimento pode ser observada na tabela XVIII.

\begin{tabular}{|c|c|c|c|c|}
\hline [metal] em ppm & $\mathrm{Ml-Pb}$ & $\mathrm{VH}-\mathrm{Cu}$ & $\mathrm{VH}-\mathrm{Ni}$ & $\mathrm{VH}-\mathrm{Cu}\left(2^{\mathrm{a}}\right)$ \\
\hline antes da recuperação & 1083,00 & 600,00 & 500,00 & 128,56 \\
\hline depois da recuperação & 1022,00 & 616,00 & 322,00 & 118,00 \\
\hline pH inicial & 3,75 & 3,85 & 3,50 & 3,60 \\
\hline pH final & 3,55 & 3,75 & 3,45 & 4,80 \\
\hline
\end{tabular}

Tabela XVIII: Concentração dos íons metálicos liberados das amostras para a solução de lixiviação (EDTA 0,04M). São fornecidos, também, os valores dos pHs (inicial e final) de cada sistema.

A recuperação das amostras na fixação de elementos pesados em solução, utilizando EDTA $(0,04 \mathrm{M})$ mostrou-se muito eficiente. A maior parte dos metais, antes adsorvida nas vermiculitas, foi liberada para a solução, sem provocar grandes modificações nas estruturas das mesmas.

$\mathrm{Na}$ prática, este método torna-se muito oneroso devido ao próprio custo do EDTA e ao volume gasto em cada processo de recuperação. No entanto, para fins de pesquisa, o seu uso neste experimento torna clara a possibilidade de se reciclar a vermiculita nos processos de retenção de metais pesados em solução. Além disso, a análise mineralógica por DRX mostra que a cristalinidade do mineral é mantida, mesmo após vários tratamentos. 


\section{CONCLUSÕES}

Serão abordadas, a seguir, as conclusões mais significativas de cada etapa deste trabalho.

Os dados analíticos obtidos neste trabalho permitiram estabelecer a fórmula estrutural da vermiculita de Massapé-Paulistana (PI) e, consequentemente, constatar que se trata de um mineral de carga estrutural relativamente alta $(-0,73)$. Ainda a partir destes dados pode-se estimar, através do diagrama triangular de Foster (1963), a composição da flogopita como possivelmente aquela que teria dado origem ao mineral.

A capacidade de troca catiônica da vermiculita crua, de modo geral, apresentou-se mais alta que a da expandida. A CTC inferior da vermiculita expandida se deve à perda de água interfoliar, importante no papel de remoção de cátions em vermiculita.

Desenvolveu-se método simplificado de determinação de CTC a partir daquele proposto por Nicot \& Facundo (1970). Este novo método gera resultados bastante coerentes, com a vantagem principal de ser mais rápido, uma vez que se diminuiram etapas.

O conjunto de ensaios físico-químicos permitiram verificar que, no geral, no início do tratamento das amostras com soluções salinas, as taxas de sorção da fase líquida para a sólida são altas, logo diminuindo até estabelecimento do equilíbrio. Quando as soluções de tratamento são renovadas periodicamente, a taxa de sorção aumenta e consequentemente o tempo gasto no processo de troca iônica diminui.

A granulometria das amostras, a natureza dos cátions (interfoliares e do meio), bem como a concentração de ions nas soluções, influenciam no comportamento de troca cationica da vermiculita. Neste trabalho verificou-se que os íons das soluções com raio iônico elevado, como bário, potássio e sódio são os que, mais efetivamente, conseguem ser trocados pelos cátions interfoliares de uma vermiculita. Isto se dá graças à forte influência do grau de hidratação dos cátions interfoliares, que são maiores que daqueles deslocados por eles. Tal fato não ocorreu intensamente com os íons menores, como magnésio e oxônio, por ambos apresentarem graus de hidratação maiores que os dos cátions interfoliares do mineral. Conclui-se, então, que quanto maior o grau de hidratação do cátion interfoliar do mineral, em relação ao do cátion da solução, maior é a sua facilidade de troca. 
Diante de tal confirmação a amostra predominantemente cálcica de MassapéPaulistana (PI) foi tratada quimicamente para se obter amostras com o ín oxônio no lugar dos cátions interfoliares originais, uma vez que se sabe que o oxônio pode ser facilmente deslocado por outros cátions da fase aquosa, até mesmo a elevados valores de $\mathrm{pH}$ (Schulthess \& Huang 1990).

As amostras de vermiculita saturadas com $\mathrm{H}_{3} \mathrm{O}^{+}$são eficientes na troca de metais pesados como chumbo, cobre e níquel, como pode ser observada nas experiências em que se utilizaram efluente industrial e soluções ricas em metais pesados (preparadas em laboratório). As amostras cruas (M-1) e aquelas saturadas com magnésio (VMg-30) monstraram, na mesma experiência, boa eficiência nos processos de troca, principalmente, com os íns chumbo e cobre. Assim sendo, dependendo do tipo de metal presente no efluente, pode-se utilizar simplesmente a vermiculita natural, desde que o cátion a ser sorvido sempre apresente grau de hidratação menor que o da posição interfoliar do mineral.

Ainda, nos experimentos realizados constatou-se que a vermiculita saturada de metais pesados pode ser recuperada. Nesta etapa, para acelerar o processo de troca, foram utilizadas soluções de EDTA $(0,04 \mathrm{M})$.

Finalmente, verifica-se que a vermiculita macroscópica de MassapéPaulistana, quando devidamente tratada, pode ser utilizada em processos de troca iônica, com eventual aproveitamento de metais em solução.

A utilização da vermiculita em escala de aplicabilidade será objeto de estudo futuro. 


\section{REFERÊNCIAS BIBLIOGRÁFICAS}

ALCOVER, J.F.; GATINEAU, L.; MÉRING, J. (1973) Exchangeable cation distribution in nickel and magnesium vermiculites. Clays and Clay Minerals, 21: 131-136.

ALLOWAY, B. J. (1990) Heavy metals in soils. $1^{\text {st }}$ ed. New York, John Wiley \& Sons, Inc. 339p.

AYLMORE, L.A.G.; QUIRK, J.P. (1959) Swelling of clay-water system. Nature, 183 (4677): 1752-1753.

BAILEY, S.W. (1984) Classification and structures of the micas. In: BAILEY, S.W. (ed) Reviews in Mineralogy - Micas. Mineralogical Society of America, 13:01-12.

BARSHAD, I. (1948) Vermiculite and its relation to biotite as revealed by base exchange reactions, $\mathrm{X}$-ray analyses, differential thermal curves, and water content. The American Mineralogist, 33 (11-12): 655-678.

BARSHAD, I. (1949) The nature of lattice expansion and its relation to hydration in montmorillonite and vermiculite. The American Mineralogist, 34: 675-684.

BARSHAD, I. (1950) The effect of the interlayer cations on the expansion of the mica type of crystal lattice. The American Mineralogist, 35: 225-238.

BESSON, H.; CAILLERE, S.; HENIN, S. (1968) Aptitude a la vermiculitisation de differents micas et etude de la deshydratation de micas regeneres. Bulletin du Groupe Français des Argiles, t. XX, p.143-151.

BOWER, C. A.; GSCHWEND, F. B. (1952) Ethylene glycol retention by soil as a measure of surface and interlayer swelling. Soil Science Society of American Proceedings, 16:342-345. 
BRADLEY, W.F.; SERRATOSA, J.M. (1959) A discussion of the water content of vermiculite. In: NATIONAL CONFERENCE ON CLAYS AND CLAY MINERALS, 7. Washington D.C., 1958. Proceedings. Washington D.C., vol. 5, p. $260-270$.

CALLE, C.de la; SUQUET, H. (1988) Vermiculite. In: BAILEY, S.W. (ed.) Reviews in Mineralogy-Hydrous phyllossilicates. Mineralogical Society of America, 19: $\rightarrow \quad 455-496$.

CARLSEN, L.; BO, P. (1982) Sorption of radionuclides on clay materials. In: ENVIRONMENTAL MIGRATION OF LONG-LIVED RADIONUCLIDES. Knoxville, 1981. Proceedings, Knoxville, p. 97-109.

CARVALHO, F.M.S.; ATENCIO, D. (1993) Informatização do laboratório de difração de raios-X do Instituto de Geociências da USP. Bol. IGUSP, Publicação Especial, 16:5-8.

COELHO, A.C.V. (1986) Estudo, em escala de laboratório, do inchamento em água de vermiculitas brasileiras tratadas com soluções salinas inorgânicas. São Paulo, 244 p. (Tese de Mestrado - Escola Politécnica/USP).

COUDERC, P.; DOUILLET, P. (1973) Les vermiculites industrialles: exfoliation, caractéristiques minéralogiques et chemiques. Bull. Soc. Fr. Ceram., 99:5159.

DAS, N.C.; BANDYOPADHYAY, M. (1991) Removal of lead by vermiculite medium. Applied Clay Science, 6(3): 221-231.

DEER, F.R.S.; HOWIE, R.A.; ZUSSMAN, J. (1978) An introduction to the rock forming minerals. 11 ed. London, ed. Longman. $528 \mathrm{p}$.

DNPM, DPEM (1990) Anuário Mineral Brasileiro 1990. Brasilia.

ESLINGER, E.; PEVEAR, D. (1988) Clay Minerals. USA, SEPM SHORT COURSE n022. 356p. 
FARMER, V. C.; RUSSEL, J. D.; Mc HARDY, W. J.; NEWMAN, A. C. D.; AHLRICHS, J. L.; RIMSAITE, J. V. H. (1971) Evidence for loss of protons and octahedral iron from oxidized biotites and vermiculites. Mineralogical Magazine, 38:121-137.

FERRAZ, P. C. (1971) Vermiculita um importante mineral industrial. Rio de Janeiro, DNPM. 23p (Seção econômica).

FOSTER, M.D. (1963) Interpretation of the composition of vermiculites and hydrobiotites. In: NATIONAL CONFERENCE ON CLAYS AND CLAY MINERALS, 10, Austin, Texas, 1961. Proceedings. New York. The Macmillan Company, vol. 12, p.71-89.

GARRET, W.G.; WALKER, G.F. (1961) Swelling of some vermiculite-organic complexes in water. In: NATIONAL CONFERENCE ON CLAYS AND CLAY MINERALS, 9. Lafayette, 1960. Proceedings. Lafayette, p. 557-567.

GHABRU, S.K.; MERMUT, A.R.; ARNAUD, R.J.S. (1989) Layer-charge and cationexchange characteristics of vermiculite (weathered biotite) isolated from a gray luvisol in northeastern Saskatchewan. Clays and Clay Minera/s, 37 (2): 164-172.

GRIM, R.E. (1963) Propriedades das argilas. Cerâmica, 9 (35):18-31.

GRIM, R.E. (1968) Clay Mineralogy. 2 ed. New York, McGraw-Hill Book Company, $596 \mathrm{p}$.

GROHMANN, F. (1972) Superfície específica. In MONIZ, A. C. (ed) Elementos em Pedologia. São Paulo, editora Polígono. p.111-122.

GRUNER, J.W. (1934) The structures of vermiculites and their collapse by dehydration. The American Mineralogist, 19 (12): 557-575.

GRUNER, J.W. (1939) Ammonium mica synthesized from vermiculite. The American Mineralogist, 24 (2): 428-433. 
HARWARD, M.E.; CARSTEA, D.D.; SAYEGH, A.H. (1969) Properties of vermiculites and smectites: expansion and collapse. Clays and Clay Minera/s, 16:437-447.

HÄUSLER, W.; STANJEK, H. (1988) A refined procedure for the determination of the layer charge with alkylammonium ions. Clay Minerals, 23: 333-337.

HENDRICKS, S.B.; JEFFERSON, M.E. (1938) Crystal structure of vermiculites and mixed vermiculite-chlorites. The American Mineralogist, 23:851-863.

HENNIES, W.T.; STELLIN JR., A. (1978) A jazida de vermiculita de Paulistana, Estado do Piaul. In: CONGRESSO BRASILEIRO DE GEOLOGIA, 30. Recife, 1978. Anais. Recife, SBG, vol. 4, p. 1796-1804.

HESSE, P.R. (1971) A textbook of chemical analysis. $1^{\text {st }}$ ed. London, John Murray Ltd. 520p.

HODA, S.N.; HOOD, W.C. (1972) Laboratory alteration of trioctahedral micas. Clays and Clay Minerals, 20: 343-358.

JACKSON, E.D.; STEVENS, R.E.; BOWEN, R.W. (1967) A computer-based procedure for deriving mineral formulas from mineral analyses. Geological Survey Professional Paper, 575-C: C23-C31.

JUSTO, A.; MAQUEDA, C.; PÉREZ-RODRÍGUEZ, J.L.; LAGALY, G. (1987) An unusually expandable low charge vermiculite. Clay Minera/s, 22: 319-327.

JUSTO, A.; MAQUEDA, C.; PÉREZ-RODRÍGUEZ, J.L.; MORILLO, E. (1989) Expansibility of some vermiculites. Applied Clay Science, $4(5,6): 509-519$.

KINJO, T.; SILVEIRA, R.I.; MARCONI, A.; ABRAHÃO, I.O. (1987) Técnica de saturação de vermiculita com micronutrientes catiônicos. Anais da Escola Superior de Agricultura Luiz de Queiroz, Piracicaba, v. 44, n02, p. 1189-1199.

LAGALY, G. (1982) Layer charge heterogeneity in vermiculites. Clays and Clay Minera/s, 30 (3):215-222. 
LEE, J.D. (1980) Química Inorgânica. 3 ed. São Paulo, Editora Edgard Blücher Ltda. $507 \mathrm{p}$.

LOPEZ-GONZALEZ, J.D.; CANO-RUIZ, J. (1958) Surface area changes of a vermiculite by acid and thermal treatment. In: NATIONAL CONFERENCE ON CLAYS AND CLAY MINERALS, 6. Berkeley, 1957. Proceedings. Berkeley, p. 399-405.

MACIEL, P.; GUIMARÃES, J. E. P. (1955) A mina de vermiculita de Congonhal, Tatuí. Boletim Brasileiro de Geologia, 4: 1.

MADSEN, F.T.; MÜLLER-VONMOOS, M. (1989) The swelling behaviour of clays. Applied Clay Science, 4 (2): 143-156.

MAKUMBI, L.; HERBILLON, A.J. (1972) Vermiculitisation expérimentale d'une chlorite. Bulletin du Groupe Français des Argiles, T. XXIV, p.153-164.

MALLA, P.B.; RAVINDRANATHAN, P. ; KOMARNENI, S.; ROY, R. (1991) Intercalation of copper metal clusters in montmorillonite. Nature, 351(6327): 555-557.

MATHIESON, A. M. (1958) Structure of Mg-vermiculite. The American Mineralogist, 43:216-227.

MATHIESON, A.M.; WALKER, G.F. (1954) Crystal structure of magnesiumvermiculite. The American Mineralogist, 39: 231-255.

MORA SOLIS, F.A. (1981) Fixação de fósforo em solos que receberam quantidades variáveis das argilas vermiculita e caulinita. São Paulo, 88 p. (Tese de mestrado - ESALQ/USP).

NEWMAN, A.C.D. (1987) The interaction of water with clay mineral surfaces. In: NEWMAN, A.C.D. (ed.) Chemistry of Clays and Clay Minerals. London, Mineralogical Society, p. 237-274.

NICOT, B.N.F.; FACUNDO, V. (1970) Contribuição à determinação da capacidade de troca de cátions em argilas. Revista Cerâmica, 16 (62):137-146. 
OBUKHOVSKAYA, T.D. (1982) Mercury sorption by soil minerals. Soviet Soil Science, 14 (3): 49-55.

OLIS, A.C.; MALLA, P.B.; DOUGLAS, L.A. (1990) The rapid estimation of the layer charges of 2:1 expanding clays from a single alkylammonium ion expansion. Clay Minerals, 25: 29-50.

PEDRO, G. (1980) Papel e influência das características mineralógicas sobre as modalidades de organização dos materiais argilosos nas condições de meio superficial. In: REUNIÃO ABERTA DA INDÚSTRIA DA CAL, 4. São Paulo, 1979. Anais. São Paulo, Associação Brasileira dos Produtores de Cal. Boletim n012, p. 14-59.

QUIRK, J.P.; THENG, B.K.G. (1960) Effect of surface density of charge on the physical swelling of lithium montmorillonite. Nature, 187 (4741): 967-968.

RAMAN, K.V.V.; JACKSON, M.L. (1964) Vermiculite surface morphology. In: NATIONAL CONFERENCE ON CLAYS AND CLAY MINERALS, 12, Atlanta, Georgia, 1963. Proceedings. New York, The Macmillan Company, vol. 19, p. 423-429.

RANGER, J.;DAMBRINE, E.; ROBERT, M.; RIGHI, D.; FELIX, C. (1991) Study of current soil-forming processes using bags of vermiculite and resines placed within soil horizons. Geoderma, 48: 335-350.

RAYMAHASHAY, B.C. (1987) A comparative study of clay minerals dor pollution control . Journal Geological Society of India, 30 (5): 405-413.

ROBERT, M. (1968) Etude experimentale sur les processus de vermiculitisation des micas trioctaedriques bilan de l'evolution et conditions de genese des vermiculites. Bulletin du Groupe Français des Argiles, t. XX, p.153-171.

ROBERT, M.; BARSHAD, I. (1972) Transformation expérimentale des micas en vermiculites ou smectites propriétés des smectites de transformation. Bulletin du Groupe Français des Argiles, t. XXIV, p.137-151.

ROBERT, M.; PEDRO, G. (1966) Transformation d'une phlogopite en vermiculite par extraction du potassium. Bulletin du Groupe Français des Argiles, 17:3-17. 
ROBERT, M.; RAZZAGUE-KARIMI (1974) Evolution des micas trioctaédriques en présence d'acides organiques. Bulletin du Groupe Français des Argiles, t. $X X V I$, p.307-317.

ROCHA, G.C.; CERRI, C.C. (1992) Utilização de vermiculitas como minerais teste no monitoramento da dinâmica atual de coberturas pedológicas. Revista Brasileria de Geociências, 22 (1): 112-117.

ROSENBURG, J.P. (1972) Estudo de vermiculitas brasileiras. São Paulo, 190 p. (Tese de doutorado - Instituto de Química/USP).

ROY, R.; ROMO, L. A. (1957) Weathering studies - 1: New data on vermiculite . Journal Geol., 65:603-610.

SALATI, E.; REICHARDT, K.; URQUIAGA, S. (1980) Efeitos da adição de vermiculita na retenção e armazenamento de água por latossolos. Revista Brasileira de Ciência do Solo, 4 (3): 125-131.

SCHOFIELD, R. K. (1949) Effect of pH on eletric charges carried by clay particles. Journal of Soil Science, 1:1-8.

SCHULTHESS, C.P.; HUANG, C.P. (1990) Adsorption of heavy metals by silicon and aluminum oxide surfaces on clay minerals. Soil Science Society of America Journal, 54 (3): 679-688.

SHIROZU, H.; BAILEY, S. W. (1966) Crystal struture of two layer Mg-vermiculite. The American Mineralogist, 51:1124-1143

SOUZA, J. V.; SOUZA SANTOS, P.; SOUZA SANTOS, H. (1978) Caracterização mineralógica de algumas argilas niqueliferas brasileiras. Cerâmica, 24( 108): 434-446.

SOUZA SANTOS, P. (1975) Tecnologia de Argilas. São Paulo, editora Edgard Blücher Ltda., vol. 1, $340 \mathrm{p}$. 
STELLIN JR, A. (1969) Aproveitamento econômico da jazida de vermiculita do Bairro de Congonhal, Tatuí, SP. In: CONGRESSO BRASILEIRO DE GEOLOGIA,23. Salvador, 1969. Resumos das Conferências e das Comunicações, SBG (Boletim especial n० 1), p38-39.

STONE, L.F.; LIBARDI, P.L.; REICHARDT, K. (1986) Produtividade do arroz e absorção de nitrogênio afetadas pelo veranico e pela adição de vermiculita ao solo. Pesquisa Agropecuária Brasileira, Brasília, 21(2): 117-125.

STUMM, W.; MORGAN, J. J. (1970) Aquatic chemistry (an introduction emphasizing chemical equilibria in natural waters. $1^{\text {st }}$ ed. New York, WileyIntescience. 583p.

TOLEDO-GROKE, M. C. (1986) Intemperismo das rochas mineralizadas em cobre do Salobo $3 A$, Serra dos Carajás (mecanismos de alteração dos minerais primários e localização do cobre nos produtos secundários). São Paulo, 173p. (Tese de doutoramento - Instituto de Geociências/USP).

VALI, H.; HESSE, R. (1992) Identification of vermiculite by transmission electron microscopy and X-ray diffraction. Clay Minerals, 27: 185-192.

VAN OLPHEN, H. (1960) Ion adsorption on clays: a review. In: NATIONAL CONFERENCE ON CLAYS AND CLAY MINERALS, 8. Norman, Oklahoma, 1959. Proceedings, New York, The MacMillan Company, vol. 8, p.115.

WALKER, G. F. (1956) Diffusion of interlayer water in vermiculite. Nature, 177: 239240.

WALKER, G.F. (1959) Diffusion of exchangeable cations in vermiculite. Nature, 184 (4696): 1392-1393.

WALKER, G.F. (1960) Macroscopic swelling of some vermiculite crystals in water. Nature, 187 (4734): 312-313.

WALKER, G.F. (1972) Vermiculite Minerals. In: BROWN, G. (ed) The X-Ray identification and crystal structures of clay minerals. London, Mineralogical Society, p. 297-324. 
WALKER, G.F.; COLE, W.F. (1957) The vermiculite minerals. In: MACKENZIE, R.C. (ed.) The diferential thermal investigation of clays. London, Mineralogical Society, p. 191-206.

WEAVER, C. E. (1958) Potassiun fixation by expandable clay mineral. The American Mineralogist, 43:839-861.

WEBB, T.H. (1823) New localities of tourmaline and talc - Extract from a letter to the editor. American Journal of Science and Arts, 7:55.

WEY, R.; LE DRED, R. (1972) Vermiculite et vermiculitisation. Bulletin du Groupe Français des Argiles, t. XXIV:111-134.

WUTKE, A.C.; CAMARGO, O.A. (1972) Adsorção e troca iônica. In: MONIZ, A.C. (ed) Elementos de pedologia. São Paulo, Editora Polígono, p. 125-147. 